

\title{
IMPLICACIÓN DE LA MONOAMINO OXIDASA EN CONDUCTAS INDUCIDAS POR ETANOL
}

\author{
TESIS DOCTORAL \\ Presentada por: \\ Miguel Ángel Escrig Ayuso \\ Dirigida por: \\ Dr. D. Carlos M. González Aragón
}

Castellón, Febrero de 2016 



\section{$\boldsymbol{f y}_{7}$ \\ Uy \\ JAUME•I}

Dr. D. Carlos M. González Aragón, Catedrático de Universidad del área de Psicobiología en el Departamento de Psicología Básica, Clínica y Psicobiología de la Universitat Jaume I de Castellón,

\section{CERTIFICA:}

Que la presente Tesis Doctoral titulada “Implicación de la Monoamino Oxidasa en Conductas Inducidas por Etanol" ha sido realizada por Miguel Angel Escrig Ayuso bajo mi dirección en el grupo de investigación Psicofarmacología del Alcohol de la Universitat Jaume I, y cumple con los requisitos necesarios de calidad y originalidad para su defensa.

Y para que conste a los efectos oportunos, firmo el presente documento en Castellón, a 2 de Noviembre de 2015.

Fdo: Carlos M. González Aragón 

A Marc y Mamen, mis M\&M's 



\section{AGRADECIMIENTOS}

A través de estas palabras me gustaría transmitir mi más sincero agradecimiento a todas las personas que de un modo u otro han colaborado en el desarrollo de esta tesis. Espero que sirvan para mostrarles mi reconocimiento.

En primer lugar, al director de esta tesis doctoral, Dr. Carlos M. González Aragón, por su dedicación y esfuerzo por sacar adelante este trabajo de investigación. Sus consejos y enseñanzas, tanto a nivel profesional como personal, han sido indispensables en la realización de esta tesis doctoral.

A la Dra. Mercè Correa Sanz, por brindarme su amistad durante todo este proceso y guiarme en mis primeros pasos en la investigación.

Al Dr. Raúl Pastor Medall, por estar dispuesto a ayudar en cualquier momento y participar en esta tesis de manera desinteresada.

A la Dra. Laura Font Hurtado, por su ayuda y su amistad.

A los Drs. Juan Carlos Ledesma Llorente y Pablo Baliño Remiro, por su compañerismo y colaboración durante estos años que hemos estado juntos.

A las Dras. Marta Miquel Salgado-Araujo y Carla Sanchís Segura, por contestar siempre a mis preguntas, por muy descabelladas que fueran.

A Alicia Dosda, por estar siempre a mi lado, su cuidado de los animales y su colaboración con el cromatógrafo de gases y con el espectrofotómetro han sido fundamentales en la realización de este trabajo. A Gemita, por su amistad y su inestimable ayuda en mis primeros pasos con los animales en el laboratorio. A Jordi Pilar, un excelente amigo informático, por su ayuda en las cuestiones técnicas durante tantos años.

A tantos investigadores que han pasado por el laboratorio y han dejado su huella en mi... Ernesto Tarragón, Marta Pardo, Laura López, Maria Carbó, Noemí San Miguel... 
A mis padres, hermanos y sobrino, por no entender nada de lo que hago y aún así apoyarme e intentar ayudar en todo.

Finalmente, a mis M \& M's, pues sin ell@s nada sería posible. My sweetty Marc, saber dar los mejores abrazos del mundo y explicar las cosas como nadie puede hacerlo; a pesar de tu corta edad, bien sabes darme sabios consejos. Mamen, sin ti esta tesis no habría existido y mi vida carecería de sentido. Nunca llegaré a poder devolverte ni una milésima parte de las muchas cosas que me has dado, me das y espero que me sigas dando... 


\section{INDICE}

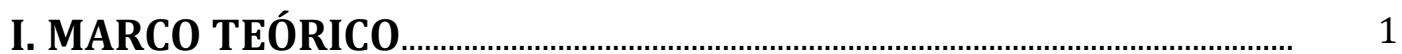

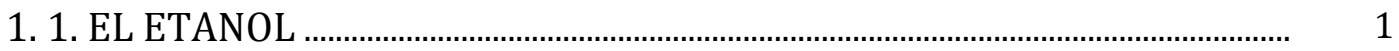

1.1.1. Farmacocinética del etanol .................................................................... 1

1.1.1.1. Metabolismo hepático...........................................................................................

1.1.1.2. Metabolismo en el Sistema Nervioso Central ......................................................

1.1.2. Farmacodinámica del etanol....................................................................

1.1.2.1. Mecanismos de acción moleculares.........................................................................

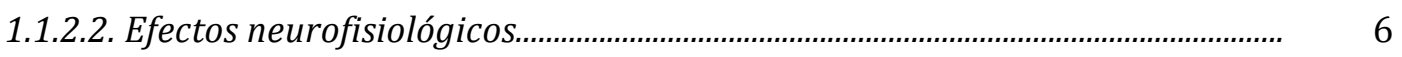

1.2. LA HIPÓTESIS DEL ACETALDEHÍDO .................................................................. 11

1.2.1. Efecto de la manipulación del metabolismo central del etanol en

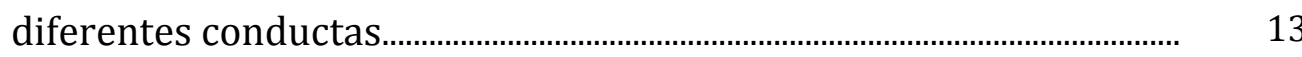

1.2.1.1. Estudios sobre la actividad locomotora ………………………………………...... 13

1.2.1.2. Estudios sobre el consumo voluntario de etanol.................................................. 16

1.2.1.3. Estudios sobre la preferencia de lugar condicionada inducida por etanol... $\quad 18$

1.2.2. Efecto de la administración de acetaldehído en diferentes conductas..

1.2.2.1. Efecto del acetaldehído sobre la actividad locomotora..................................... 18

1.2.2.2. Efectos sobre el consumo voluntario del acetaldehído....................................... 19

1.2.2.3. Efectos sobre la preferencia de lugar condicionada inducida por acetaldehído...

1.2.3. Consecuencias de las manipulaciones del acetaldehído derivado del metabolismo del etanol en los efectos psicofarmacológicos inducidos del etanol.

1.2.3.1. Secuestro de acetaldehído y estimulación locomotora inducida por etanol

1.2.3.2. Secuestro del acetaldehído y consumo voluntario de etanol.

1.2.3.3. Secuestro de acetaldehído y preferencia de lugar condicionada inducida por etanol. 
1.3. LA MODULACIÓN DE LOS NIVELES DE PERÓXIDO DE HIDRÓGENO ENCEFÁLICOS COMO ESTRATEGIA PARA EL ESTUDIO DEL PAPEL DEL COMPUESTO I EN LOS EFECTOS REFORZANTES DEL ETANOL...

1.4. LA MONOAMINO OXIDASA

1.4.1. Isoenzimas de la monoamino oxidasa 30

1.4.2. Inhibición de la monoaminooxidasa............................................................... 32

1.4.3. Desactivación genética de la MAO.................................................................. 33

1.4.4. Efectos estudiados de la inhibición de la MAO en conductas inducidas por etanol.

3.1. SUJETOS

3.2. DROGAS

3.3.1. Actividad locomotora

3.3.2. Sensibilización. 45

3.3.3. Consumo voluntario en acceso restringido 46

3.4. PROCEDIMIENTOS BIOQUÍMICOS..

3.4.1. Actividad enzimática de la catalasa cerebral........................................................

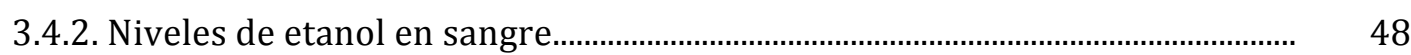

3.5. FASE EXPERIMENTAL.........................................................................................

3.5.1. Experimentos sobre actividad locomotora.............................................................. 49

3.5.2. Experimentos sobre la sensibilización motora inducido por etanol................ $\quad 50$

3.5.3. Experimentos sobre consumo voluntario de etanol.................................... 51

3.5.4. Experimentos sobre la actividad enzimática de la catalasa......................... 52

3.5.5. Experimentos sobre los niveles de etanol en sangre.......................................... 52 
IV. RESULTADOS ......................................................................................

4.1. EXPERIMENTOS SOBRE ACTIVIDAD LOCOMOTORA................................... 53

4.2. EXPERIMENTOS SOBRE LA SENSIBILIZACIÓN MOTORA INDUCIDO POR ETANOL

4.3. EXPERIMENTOS SOBRE CONSUMO VOLUNTARIO DE ETANOL 65

4.4. EXPERIMENTOS SOBRE ACTIVIDAD ENZIMÁTICA DE LA CATALASA 72

4.5. EXPERIMENTOS SOBRE LOS NIVELES DE ETANOL EN SANGRE............ 73

V. DISCUSIÓN... 75

VI. CONCLUSIONES

83

VII. REFERENCIAS

85 



\section{PREFACIO}

La catalasa utiliza como cosubstrato el peróxido de hidrógeno $\left(\mathrm{H}_{2} \mathrm{O}_{2}\right)$ para formar el compuesto I (catalasa- $\mathrm{H}_{2} \mathrm{O}_{2}$ ) que es el principal sistema de metabolismo de etanol (EtOH) en el sistema nervioso central (SNC). De este modo, el etanol se metaboliza a acetaldehído por la actividad del compuesto I. Se ha demostrado que las manipulaciones farmacológicas que varían los niveles de catalasa central producen una modificación de los efectos que el EtOH produce en roedores. También se han observado resultados similares cuando se han comparado estirpes de ratones con diferentes niveles de catalasa central. Por lo tanto, los niveles de catalasa central de un organismo han sido propuestos, por numerosos autores, como el factor limitante de la cantidad de acetaldehído que es producido en el cerebro, que es un elemento determinante para producir los efectos psicofarmacológicos que causa el etanol. Se ha observado que secuestradores de acetaldehído provocan un bloqueo de las conductas inducidas por el EtOH. El peróxido de hidrógeno es uno de los factores limitantes de la actividad de la catalasa central en el metabolismo cerebral del etanol. Se ha demostrado que variaciones de los niveles de $\mathrm{H}_{2} \mathrm{O}_{2}$ presentes en el SNC tienen como consecuencia variaciones en la actividad de la catalasa encefálica.

En la presente tesis doctoral estudiamos si la monoamino oxidasa (MAO) puede ser una fuente de peróxido de hidrógeno necesario para la formación del compuesto I y, por tanto, para el metabolismo cerebral del etanol, en la actividad locomotora inducida por EtOH y en la ingesta voluntaria de etanol. Para ello se han utilizado dos inhibidores irreversibles de la MAO, cada uno de ellos específico para cada isoforma, la clorgilina (inhibidor de la MAO-A) y el deprenil (inhibidor de la MAO-B). Nuestra hipótesis de trabajo es que la inhibición de la monoamino oxidasa provocará una disminución en los niveles de $\mathrm{H}_{2} \mathrm{O}_{2}$ presentes en el SNC que producirá una disminución en la formación del compuesto I y como consecuencia habrá un menor metabolismo cerebral del etanol, lo que provocará una reducción de la producción de acetaldehído a nivel central. La reducción de los niveles de 
acetaldehído en el SNC tendrá como consecuencia un bloqueo de las conductas estudiadas. Los resultados obtenidos nos llevan a proponer a la monoamino oxidasa cerebral como la fuente principal de peróxido de hidrógeno en el SNC. 


\section{MARCO TEÓRICO}

\subsection{EL ETANOL}

\subsubsection{Farmacocinética del etanol}

\subsubsection{Metabolismo hepático}

El etanol se oxida a acetaldehído en la mayoría de los tejidos del cuerpo por los enzimas: alcohol deshidrogenasa (ADH), catalasa y el sistema microsomal oxidativo (MEOS), específicamente el citocromo P450 2E1 (CYP450 2E1) (Techske y cols., 1976). El hígado es la principal vía para el metabolismo del etanol en el consumo de etanol estándar y es la ADH la enzima que mayoritariamente participa en este metabolismo (Lieber y De Carli, 1970). El acetaldehído formado es metabolizado a acetato por la aldehído deshidrogenasa (ALDH) presente en el mismo hígado. El MEOS en una administración aguda de etanol participa en el metabolismo de este entre un 3 y un 8\% (Thurman y Handler, 1989), sin embargo si la administración es crónica puede alcanzar valores de hasta el 22\% del metabolismo del etanol mediante el MEOS (Thurman y Handler, 1989).

Hay autores que señalan que la implicación de la catalasa en el metabolismo del etanol pudiera ser dudosa por el bajo nivel de peróxido de hidrógeno en el organismo, que es necesario para formar el complejo catalasa- peróxido de hidrógeno (compuesto I) (Ito y Lieber, 1993; Lieber y De Carli, 1970; Techske y cols., 1976). Pero existen pruebas indicando que los niveles de peróxido de hidrógeno presentes en algunas mediciones in vitro pudieran ser menores de los existentes in vivo, donde hay fuentes peroxidativas endógenas, lo que estaría reduciendo la importancia de la vía metabólica mediada por la catalasa. Así, la adición de ácidos grasos o albúmina (que elevan los niveles de $\mathrm{H}_{2} \mathrm{O}_{2}$ ) a estas preparaciones, hacen que el compuesto I se convierta en el principal responsable de la oxidación del etanol en ausencia de ADH (Handler y Thurman, 1985). 


\subsubsection{Metabolismo en el Sistema Nervioso Central}

Sin embargo, en el cerebro los otros dos sistemas que están involucrados en el metabolismo del etanol toman relevancia, dado que la $\mathrm{ADH}$ en presencia de concentraciones bajas o moderadas de etanol posee una limitada actuación (Raskin y Sokolov, 1972). Hasta 1998, se creía que no existía la isoforma I de la $\mathrm{ADH}$ en el cerebro (es la isoforma que tiene una mayor afinidad por el etanol) (Lands, 1998). Posteriormente se demostró la presencia de ADH I y ADH IV en ciertas estructuras del SCN como son el cerebelo, hipocampo y corteza cerebral del cerebro de rata (Martinez y cols., 2001), pese a ello no se ha podido implicar en el metabolismo del etanol. Tanto en humanos como en roedores la isoforma más abundante de la ADH es la III (Mori y cols., 2000; Rout, 1992). Sin embargo estas isoforma tiene una baja afinidad por el etanol y difícilmente es activada por este, ya que incluso en intoxicaciones etílicas severas no se alcanzan las concentraciones necesarias para que su contribución sea relevante (Gill y cols., 1992).

Por otro lado, el sistema MEOS y más concretamente el CYP450 2E1 esta presente en el SNC (Bhagwat y cols., 1995; Norris y cols., 1994). Se conoce que puede ser inducido por el etanol y que ante una administración aguda puede incrementar su porcentaje de participación en el metabolismo del etanol del 3 al $5 \%$ y que puede incrementarlo hasta 10 veces tras una administración crónica de etanol, aunque parece ser que el CYP450 2E1 supone menos del 1\% de los citocromos contenidos en el MEOS (Hunt, 1996). Actualmente se sabe que ante situaciones de consumo crónico o altas concentraciones de etanol, el sistema enzimático del CYP450 2E1 ejerce una contribución importante (Gill y cols., 1992; Montoliu y cols., 1994; Vasiliou y cols., 2006).

El sistema que ha sido propuesto como el mayor sistema enzimático implicado en el metabolismo del etanol en el SNC es el compuesto I. Así la catalasa utilizando como cosubstrato el peróxido de hidrógeno presente en el organismo forma el complejo enzimático conocido como compuesto I (catalasa- $\mathrm{H}_{2} \mathrm{O}_{2}$ ), que es capaz de oxidar el etanol transformándolo en acetaldehído. Hay muchos estudios que apoyan la existencia del metabolismo del etanol en el cerebro por el 
compuesto I (Aragón y cols., 1992b; Gill y cols., 1992). Estudios in vivo con inhibidores del compuesto I como el 3-amino-1,2,4-triazole (AT), la cianamida o el 4-hidroxipirazol demostraron que la inhibición del compuesto I puede prevenirse si administramos etanol con anterioridad (Cohen y cols., 1980, Aragon y cols., 1991). Dado que el AT es un inhibidor no competitivo del compuesto I, es decir que tras la reacción entre el AT y el compuesto I es necesaria una nueva síntesis de proteína para recuperar su actividad (Heim y cols.,1955). Puesto que el etanol constituye un substrato con gran afinidad para el compuesto I, su acción protectora sobre la inhibición de la catalasa in vivo supone una evidencia indirecta de que el alcohol es un substrato de la actividad peroxidativa de la catalasa y por tanto, de la oxidación de etanol a acetaldehído en el SNC.

Otra evidencia directa aparece en diversos estudios con homogenados de cerebro, astrocitos en cultivo y células embrionarias de rata (Aragón y cols., 1992b; Eysseric y cols., 1997; Gill y cols., 1992; Hamby-Mason y cols., 1997) que al ser incubados con etanol produjeron niveles significativos de acetaldehído. Y varios estudios han informado de que esta oxidación del etanol en el cerebro y la formación de acetaldehído consiguiente se relacionan con la actividad del compuesto I (Aragón y cols., 1992b; Gill y cols., 1992; Aragón y Amit, 1993). Por otra parte, está demostrado que el deterioro de la actividad del sistema catalasa$\mathrm{H}_{2} \mathrm{O}_{2}$ mediante manipulaciones farmacológicas AT y azida sódica (Aragón y cols., 1992b; Gill y cols., 1992) o genéticamente (Aragón y Amit, 1993), redujo significativamente la producción de acetaldehído en cerebros homogeneizados incubados con etanol. Aragón y cols. (1992b) y Gill y cols. (1992), también exploraron la adición de peróxido y de agentes generadores de $\mathrm{H}_{2} \mathrm{O}_{2}$ (glucosa oxidasa) en los homogenados de cerebro descubriendo un aumento en la formación de acetaldehído.

Una tercera evidencia viene por estudios que comparan la capacidad de producción de acetaldehído en ratas recién nacidas y adultas. La producción de acetaldehído es mayor en los homogeneizados cerebrales de las crías, los cuales demuestran tener una mayor actividad catalasémica (Gills y cols., 1992; HambyMason y cols., 1997). Del mismo modo, ratones acatalasémicos de la cepa C3HA 
producen una cantidad de acetaldehído significativamente menor que los ratones con niveles de catalasa normales (Aragon y cols., 1992a; Aragon y Amit, 1993).

En resumen, con todos estos estudios se puede concluir que el compuesto I es el sistema más fuertemente implicados en el metabolismo del etanol para formar acetaldehído en el sistema nervioso central. Parece posible que tanto la catalasa y $\mathrm{H}_{2} \mathrm{O}_{2}$ determinen la tasa de formación de acetaldehído en el cerebro, pero se desconoce cuáles son los productores de $\mathrm{H}_{2} \mathrm{O}_{2}$ que estarían involucrados en la formación del compuesto I.

\subsubsection{Farmacodinámica del etanol}

La mayoría de drogas ejercen su acción interaccionando con un receptor específico, siendo necesario para que esto ocurra una relativa complejidad molecular. El etanol es, sin embargo, una molécula con propiedades físico-químicas y estructurales muy simples, lo que limita su posible especificidad para interactuar con un tipo concreto de receptor neural (Fadda y Rosetti, 1998). Debido a su simplicidad estructural y a las carencias de un carbón asimétrico, el etanol sólo posee dos sitios lábilmente reactivos: un grupo $\mathrm{OH}$ y una cadena corta de dos átomos de carbono (Fadda y Rosetti, 1998; Lovinger y Crabbe, 2005). Como resultado de su escasa reactividad, no forma enlaces iónicos o covalentes con otras moléculas, por lo que desde un punto de vista farmacológico, el etanol es una droga que posee escasa potencia (Lovinger y Crabbe, 2005). De modo que, de existir un receptor para el alcohol, éste tiene una afinidad notablemente baja por su ligando si se compara con todos los receptores conocidos. La débil potencia del etanol impide la aplicación de ciertas técnicas farmacológicas para la detección de uniones estereoselectivas entre el etanol y dianas moleculares específicas. Estas dificultades experimentales han imposibilitado el esclarecimiento del mecanismo de acción de esta droga. Por otro lado, debido a que su coeficiente de partición es de 0.5 , el etanol es una sustancia tanto hidrofílica como lipofílica, lo que le permite atravesar las membranas celulares fácilmente y situarse en todos los compartimentos de la célula. A pesar de las limitaciones derivadas de la simplicidad molecular de este alcohol, se han observado algunas interacciones 
moleculares más o menos directas entre esta sustancia y algunos de los receptores de los sistemas de neurotransmisión.

\subsubsection{Mecanismos de acción moleculares}

Sabemos que el etanol administrado de forma aguda es capaz de incrementar la fluidez de la membrana celular, haciendo que cambie su morfología. Las proteínas y los lípidos de la membrana tienen una orientación específica. Esta configuración no es rígida sino que las proteínas están libres y difusamente unidas a la bicapa lipídica, contribuyendo a la fluidez de membrana. Las últimas teorías sugieren que el etanol no causa una alteración generalizada de la bicapa lipídica, sino que presenta una afinidad variable por los microdominios de la membrana celular (Wang y cols., 1993). De este modo, el etanol actúa selectivamente, dependiendo del grado de afinidad de esta molécula por ciertas estructuras y dominios de la membrana, y cambia el estado de determinadas enzimas, bombas y canales (Peoples y cols., 1996). Tras la administración crónica de etanol, este fenómeno desarrolla tolerancia (Hunt, 1985; Ollat y cols., 1988).

Existen datos más que suficientes que apoyan la idea de que el receptor $\mathrm{GABA}_{A}$ puede ser una de las dianas moleculares del etanol. El etanol comparte algunas de sus acciones farmacológicas con los barbitúricos y las benzodiacepinas, incluyendo las acciones sedativas y ansiolíticas, así como la tolerancia y la dependencia cruzada (Khanna y cols., 1991). Las similitudes entre algunas de las acciones del alcohol, los barbitúricos y las benzodiacepinas, fueron la base de teorías iniciales en las que se sugirió que estas tres drogas comparten un mecanismo de acción común ligado al receptor $\mathrm{GABA}_{\mathrm{A}}$. Las benzodiacepinas, como el alcohol y los barbitúricos, no compiten con el GABA, sino que tienen su propio sitio de unión específico en el receptor. El resultado, sin embargo, es común: incrementar el efecto del GABA en la apertura del canal de cloro permitiendo que los iones entren a través de la membrana plasmática (Boehm y cols., 2004; Goldstein, 1995). Concretamente, recientes estudios realizados en oocitos, neuronas aisladas y preparados de cortes cerebrales, apoyan la idea de que la coincidencia de determinadas subunidades del receptor $\operatorname{GABA}_{A}(\alpha 4, \alpha 6, \beta 2, \beta 3$ y $\delta)$ 
haría más probable que el etanol potenciara la respuesta al GABA (Lovinger y Crabbe, 2005).

Por otra parte, estudios en oocitos han mostrado una interacción directa entre el receptor NMDA y el etanol (Wright y cols., 1996). El etanol bloquea al receptor NMDA mediante dos posibles mecanismos: uno dependiente del sitio de la glicina (Buller y cols., 1995; Faingold y cols., 1998) y otro que está mediado por una unión alostérica independiente del sitio de unión del glutamato y la glicina (Faingold y cols., 1998; Wright y cols., 1996). El etanol también interacciona directamente con los dominios de transmembrana de las receptores ionotrópicos $5 \mathrm{HT}_{3}$ (Zhang y cols., 2002). Además de estas interacciones directas del alcohol con algunos receptores, sabemos que el etanol produce efectos complejos sobre los diferentes sistemas de neurotransmisión y neuromodulación.

\subsubsection{Efectos neurofisiológicos del etanol}

A nivel celular, se ha demostrado que el etanol, tanto in vivo como in vitro, reduce el transporte de los iones de calcio a través de la membrana en los canales iónicos dependientes de voltaje, al tiempo que facilita la exocitosis de $\mathrm{K}^{+}$dependiente del contenido de calcio en el medio intracelular (Hunt, 1985). Asimismo, administrado de forma crónica, el etanol provoca un aumento en la expresión de las subunidades $\alpha 1 C, \alpha 1 D$ y $\alpha 2 / \delta 1$ de los canales de calcio de tipo L (Hunt, 1993; Katsura y cols., 2005).

Respecto a los efectos del alcohol en la neurotransmisión GABAérgica, la administración aguda de etanol, aumenta la captación de $\mathrm{Cl}^{-}$en el interior de la célula, lo que sugiere que el etanol pudiera aumentar la inhibición neuronal mediada por el GABA (Carta y cols., 2004; Mihic y Harris, 1996). Se ha observado además, que la administración aguda de este alcohol aumenta la liberación de GABA en el hipocampo (Durand y cols., 1981) y la amígdala central (Roberto y cols., 2003, 2004), efecto que parece estar mediado por los receptores de CRF1 que se encuentran en dicha estructura (Nie y cols., 2004). Respecto al tratamiento crónico con etanol, estudios iniciales mostraron que se reduce la función del receptor GABA $_{A}$ (Buck y Harris, 1991; Morrow, 1995) y que predispone al 
desarrollo de tolerancia a ciertas acciones del etanol (Devaud, 2001; Hodge y cols., 1995). Sin embargo, estudios recientes señalan que en determinadas áreas cerebrales no se observan disminuciones en el número de receptores $\mathrm{GABA}_{\mathrm{A}}$ ni en su función (Weiner y Valenzuela, 2006). Así por ejemplo, en estudios in vitro realizados con cortes hipocampales se ha observado un aumento en las subunidades $\alpha 4$ y $\gamma 2$, así como una disminución en las subunidades $\alpha 1$ y $\delta$ del receptor (Cagetti y cols., 2003; Grobin y cols., 2000). Por otra parte, en cortes de amígdala central se ha observado un aumento de la señal GABAérgica (Roberto y cols., 2004).

Otro sistema de neurotransmisión estudiado como diana para las acciones del etanol ha sido el glutamatérgico. Estudios in vitro han demostrado que el alcohol, administrado de forma aguda, inhibe la función del receptor NMDA,

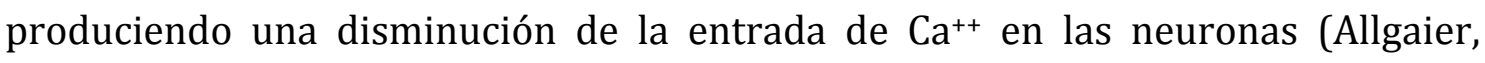
2002; Leslie y Weaver, 1993). Sin embargo, tras una administración crónica, se observa un incremento en el número de receptores NMDA en la amígdala central (Hunt, 1993; Lack y cols., 2005) y la corteza cerebral (Bao y cols., 2001), probablemente para compensar la inhibición inducida en la función del receptor. También se ha encontrado que el etanol, administrado crónicamente, incrementa el número de sitios de unión del glutamato en las membranas sinaptosomales de preparados de cerebro de rata (Chen y cols., 1997). Recientemente, ha sido observado que el tratamiento crónico con alcohol y su posterior abstinencia llevan a neuroadaptaciones en la transmisión glutamatérgica de la amígdala central (Alele y Devaud, 2005; Roberto y cols., 2004).

Otros efectos moleculares del etanol sobre la neurotransmisión son las ya conocidas consecuencias que provoca éste sobre los sinaptosomas, donde produce una reducción de la actividad de la $\mathrm{Na}^{+} \mathrm{K}^{+}$ATPasa, o sobre la $\mathrm{MAO}_{\mathrm{B}}$, a la que parece inhibir de un modo específico (Tabakoff y Hoffman, 1987).

Por otra parte, existen datos que confirman los efectos del etanol en otros sistemas de neurotransmisión. Así pues, estudios in vitro sugieren que el etanol es incapaz de alterar la liberación de la acetilcolina, así como de provocar el ligamiento de agonistas colinérgicos (Hunt, 1985; Lin y cols., 1993). In vivo, sin 
embargo, el etanol logra un incremento de la respuesta excitatoria de neuronas piramidales colinérgicas en el hipocampo (Mancillas y cols., 1986). También sabemos que a dosis bajas el etanol aumenta la liberación de acetilcolina, mientras que a dosis altas reduce dicha liberación en la corteza prefrontal (Stancampiano y cols., 2004). Por otra parte, crónicamente administrado, el etanol produce un aumento en la liberación de acetilcolina en el núcleo accumbens y en el caudadoputamen (Nestby y cols., 1997).

La noradrenalina es también un sistema de neurotransmisión sobre el que el etanol ejerce su efecto ya que es capaz de alterar los niveles de actividad noradrenérgica (Jamal y cols., 2003; Smith y cols., 1985). De este modo, el etanol administrado de forma aguda produce un decremento de los niveles de noradrenalina (Guaza y Borrell, 1985). Con la administración crónica, sin embargo, se ha observado un aumento de los niveles noradrenérgicos en la corteza cerebral (Sabria y cols., 2003).

Respecto a la serotonina (5HT), estudios in vivo han demostrado que la administración aguda de etanol produce un aumento en los niveles de serotonina en el cerebro (Le Marquand y cols., 1994; McBride y cols., 1993). Concretamente, se ha observado este efecto en el núcleo central de la amígdala (Yoshimoto y cols., 2000) y en el hipocampo (Thielen y cols., 2002). Tras una exposición crónica al etanol, se ha descrito también un incremento en la función de los receptores serotonérgicos $5 \mathrm{HT}_{2}$ y $5 \mathrm{HT}_{3}$ (McBride y cols., 2004). Es en el hipocampo y en el estriado donde fundamentalmente se ha observado un aumento de la actividad serotonérgica de estos receptores (Vasconcelos y cols., 2004). Los efectos del etanol en los receptores $5 \mathrm{HT}_{3}$, se traducen en una alteración de la actividad de otros dos sistemas de neurotransmisión como son el GABA (Klein y cols., 1994) y la dopamina (Brodie y cols., 1995).

La dopamina (DA) es uno de los neurotransmisores más estudiados debido a sus conocidas implicaciones como principal agente químico involucrado en las bases neurobiológicas de los cambios en la motivación que producen el alcohol y otras drogas de abuso (Di Chiara y cols., 2004; Hyman y Malenka, 2001; Wise, 2004). Tras una exposición aguda de etanol, se ha descrito un incremento en la 
liberación de dopamina en el núcleo accumbens (NAcb) (Di Chiara e Imperato, 1985). Esta estimulación dopaminérgica parece estar mediada por la actividad de otros sistemas de neuromodulación como los péptidos opioides endógenos, el sistema GABAérgico y el serotonérgico. De este modo, el etanol puede cambiar la señal dopaminérgica a través del receptor de serotonina $5 \mathrm{HT}_{1 \mathrm{~B}}$, que media la liberación de DA en el área tegmental ventral (ATV) (Yan y cols., 2005). En el ATV las neuronas dopaminérgicas se encuentran bajo el control inhibitorio de las interneuronas GABA. El alcohol inhibe este efecto, lo que se traduce en un aumento de la liberación de DA (Harris y cols., 1992). Sin embargo, algunos autores (Brodie y cols., 1999) han observado que el etanol es capaz de excitar las neuronas dopaminérgicas del ATV directamente sin la modulación de otros sistemas de neurotransmisión. Esta excitación es dependiente de la concentración, ya que $20 \mathrm{mM}$ es la mínima concentración de etanol con la que estos investigadores observan un incremento en la ratio de disparo de las neuronas dopaminérgicas del ATV. Con las concentraciones de $40 \mathrm{mM}$ y $80 \mathrm{mM}$ de etanol, se advierte una mayor activación, siendo 120 mM la concentración de máximo efecto.

El sistema endocannabinoide está siendo ampliamente estudiado en la actualidad debido a su estrecha relación con la neuropsicofarmacología de las drogas de abuso (Rodríguez de Fonseca y cols., 2005). En este sentido, se ha constatado que el etanol es capaz de incrementar los niveles de ligandos endógenos de los receptores cannabinoides en preparaciones celulares, como la anandamida. Además, la administración crónica de etanol induce una regulación a la baja de los receptores cannabinoides $\mathrm{CB}_{1}$ (Basavarajappa y cols., 1998), un efecto principalmente localizado a nivel hipotalámico, en el caudado-putamen e hipocampo (Ortiz y cols., 2004). Se sabe, además, que la presencia de receptores $\mathrm{CB}_{1}$ es necesaria para que el etanol ejerza algunos de sus efectos farmacológicos, como el incremento en la liberación de DA en el NAcb (Cohen y cols., 2002; Rodríguez de Fonseca y cols., 2005).

Los neuropéptidos, y en concreto los opioides endógenos, han sido desde hace dos décadas objeto de estudio en relación al etanol. Algunos autores (Miquel y cols., 2003; Sanchis-segura y cols., 2000) han sugerido que algunos de los efectos 
del etanol están mediados por las neuronas que sintetizan $\beta$-endorfinas en el núcleo arqueado hipotalámico. Así sabemos que in vivo una inyección aguda de alcohol produce liberación de $\beta$-endorfinas (Marinelli y cols., 2003), efecto que había sido previamente observado in vitro en cultivos celulares del hipotálamo (Reddy y Sarkar, 1993; Reddy y cols., 1995). Otro dato que apoya la idea de que el sistema de opioides endógeno media los efectos del etanol es que, en ratas genéticamente seleccionadas por su preferencia innata al etanol, la expresión genética de la propiomelanocortina (POMc) en el núcleo arqueado es mayor que en ratas que muestran baja preferencia por esta droga (Kinoshita y cols., 2004). El POMc es el precursor de las $\beta$-endorfinas, por lo que este estudio relaciona una mayor síntesis de $\beta$-endorfinas con la preferencia genética al consumo de alcohol.

La actividad de la adenosina está regulada por proteínas transportadoras que conducen a la adenosina dentro y fuera de la célula. Así, se ha constatado que tras la exposición aguda al etanol, disminuye la recaptación de la adenosina al interior de las células entre un 30 y un 40\%, produciendo la consiguiente acumulación extracelular de este neuromodulador (Dohrman y cols., 1997). A nivel crónico, esta acumulación extracelular de adenosina causada por el etanol, lleva a la activación del receptor A2 de este neuromodulador, al aumento de adenosina monofosfato cíclico (AMPc), a incrementos en la proteína quinasa A (PKA) y a una insensibilidad para la recaptación de adenosina (Diamond y Gordon, 1994), debido a la desensibilización de su receptor A1.

Existen también algunos segundos mensajeros que son afectados por la administración de etanol. Por ejemplo, el alcohol reduce la liberación de fosfolípidos que es estimulada por los receptores muscarínicos tipo 1. Asimismo, se ha demostrado una reducción de la concentración de guanosin monofosfato cíclico (GMPc) del encéfalo tras administraciones agudas de etanol (Ollat y cols., 1988). En cuanto al AMPc, las exposiciones agudas, provocan una inhibición de ese nucleótido seguida de regulaciones al alza en el ATV, si se cronifica la presencia del etanol (Nestler, 2001). Mención especial merece el descubrimiento de que tras la administración intermitente o continua de alcohol, las proteínas kinasas ERKs, que juegan un papel crucial en varias formas de plasticidad neural, muestran una 
disregulación en su función (Sanna y cols., 2002). Concretamente, parece que niveles moderados de alcohol reducen la activación de las ERKs, mientras que tras períodos de abstinencia se observa un incremento de estas proteínas. Dado que en esos períodos de abstinencia la activación de las ERKs es mayor ante una exposición intermitente al alcohol, se ha sugerido que este efecto es debido a una sensibilización de este parámetro observada en la abstinencia.

Como hemos revisado a lo largo de toda esta exposición, a pesar de la dificultad de encontrar una interacción específica ligando-receptor que explique todas las acciones del etanol, su administración aguda o crónica produce efectos diversos en los sistemas neuronales. Dichos efectos hacen del alcohol una sustancia oportunista que usurpa los mecanismos de control de algunos sistemas cerebrales. En concreto, el alcohol, a través de su acción más o menos directa en algunas dianas moleculares del sistema córtico-estriatal-pálido-límbico, el cual está relacionado con algunos de los circuitos cerebrales que median los trastornos adictivos, provoca cambios importantes relacionados con el aprendizaje y la motivación, que pueden derivar en última instancia en el desarrollo de alcoholismo.

En resumen, en este apartado hemos descrito como, a pesar de la dificultad para entender su mecanismo de acción molecular, el etanol es capaz de inducir numerosos efectos neurofisiológicos. Muchos de estos efectos parecen explicar el amplio rango de cambios conductuales que se observan tras la administración de esta sustancia. Así, se sabe que el alcohol posee propiedades tanto ansiolíticas como ansiogénicas, es capaz de alterar la conducta sexual, la conducta social, además de alterar los procesos de percepción, atención, memoria y aprendizaje, entre otros. En el siguiente apartado nos centraremos en describir los principales efectos psicofarmacológicos o conductuales, que convierten al etanol en una sustancia con propiedades adictivas.

\subsection{HIPÓTESIS DEL ACETALDEHÍDO}

El acetaldehído, primer metabolito de la oxidación del etanol, como mediador en los efectos psicofarmacológicos de este alcohol, tiene como hándicap que se 
necesitarían niveles relevantes del acetaldehído en el SNC tras la administración de etanol. Esta propuesta ha sido motivo de controversia entre los investigadores de este campo durante las últimas tres décadas (Deng y Deitrich, 2008; Hipólito y cols., 2007). Debido a la existencia de ALDH en la barrera hematoencefálica, que metaboliza la totalidad del acetaldehído que escapa del hígado y pasa al torrente sanguíneo tras la administración de etanol. Se sabe que serian necesarias concentraciones de acetaldehído en sangre superiores a $100 \mu \mathrm{M}$ para que el acetaldehído pasará dicha barrera metabólica (Tabakoff y cols., 1976). Además se dudó de la existencia de un metabolismo encefálico del etanol farmacológicamente relevante lo que llevó a descartar esta hipótesis, hasta la llegada de datos que demostraron la oxidación cerebral del etanol en acetaldehído a través de la enzima catalasa (Aragon y cols., 1992b; Gill y cols., 1992). Este descubrimiento supuso un giro en el estudio de la implicación del acetaldehído en las conductas inducidas por el etanol, al confirmarse su producción directamente en el SNC. Esto unido a que el acetaldehído posee efectos psicoactivos por sí mismo llevó a la postulación de "la hipótesis del acetaldehído".

Hace más de cuatro décadas que se realizaron los primeros estudios que pusieron de manifiesto la capacidad reforzadora del acetaldehído. En estos estudios se demostró que la administración de esta sustancia modula el consumo de etanol. Se observó que la administración crónica en los ventrículos cerebrales de acetaldehído incrementaba de forma significativa la preferencia por etanol en ratas a las que se les ofrecía agua y etanol (Myers y Veale, 1969). También se vio que la autoadministración intravenosa (IV) o intracerebroventricular (ICV) de acetaldehído facilitaba el consumo de alcohol (Brown y cols., 1980; Myers y cols., 1984). Ya en este siglo, se demostró que la administración IP de acetaldehído incrementa el consumo de etanol en ratas preferentes al alcohol (Quintanilla y Tampier, 2003; Tampier y Quintanilla, 2002). En resumen, podemos decir que numerosos datos ponen en relación el poder reforzador del acetaldehído con el consumo de etanol.

La hipótesis del acetaldehído está sustentada por dos fuentes de evidencia. Por una parte existe un gran corpus de datos que demuestran que el acetaldehído, 
administrado en roedores, ejerce multitud de efectos conductuales por sí mismo, mimetizando incluso al etanol en esos efectos. Por otra parte, están los estudios que señalan que manipulando el metabolismo oxidativo del alcohol se modifican sus consecuencias conductuales. El objetivo de esos trabajos es dilucidar en que medida estos cambios de conducta dependen del acetaldehído producido cerebralmente. Para ello, se han realizado diferentes tipos de aproximaciones en las que se manipula farmacológicamente tanto la síntesis como la degradación de acetaldehído en el cerebro.

\subsubsection{Efecto de la manipulación del metabolismo central del etanol en diferentes conductas}

\subsubsection{Estudios sobre la actividad locomotora}

La actividad locomotora, más concretamente la estimulación de esta por el etanol ha sido ampliamente estudiada debido a su similitud con otras drogas de abuso, la mayoría de las cuales ejercen una activación inespecífica de la conducta motora. En roedores la locomoción en un campo abierto es considerada como una conducta innata que lleva a un aumento como respuesta a una situación medioambiental novedosa. La aparición de estímulos relevantes para un organismo puede producir un incremento del arousal que se traduciría en un aumento de la locomoción (Kelley, 1993). La actividad locomotora puede ser inducida por un necesidades biológicas (búsqueda de agua o alimentos) o por la necesidad de información sobre el medio que les rodea (Kelley, 1993). Visto desde este punto de vista, la exploración es una conducta adaptativa que proporciona al individuo información sobre los posibles peligros del entorno en que se encuentra (Fowler, 1965).

En relación a los efectos estimulantes del etanol sobre la actividad locomotora existen numerosos trabajos que demuestran que una inhibición de la enzima catalasa provoca un efecto similar sobre la locomoción, independientemente del mecanismo de acción utilizado para la inhibición de la catalasa (Aragon y Amit, 1993; Correa y cols., 1999b; Escarabajal y cols., 2000; Sanchis-Segura y cols., 1999a, b). Los estudios que este equipo de investigación ha realizado con inhibidores de la catalasa incluyen tanto inhibidores competitivos 
como el 3-amino-1,2,4-triazol (AT) y la cianamida sódica, como con inhibidores no competitivos, azida sódica (AS), o con la administración crónica de plomo. En el caso del plomo una administración durante 60 días de acetato de plomo provoca una disminución en la actividad de la catalasa encefálica así como una disminución de la actividad locomotora inducida por etanol (Correa y cols., 1999b). La administración de una única dosis de AT, SA o de cianamida, provoca una reducción de la inducción locomotora que produce el etanol en el mismo sentido se produce una reducción de la actividad enzimática de la catalasa (Aragon y Amit, 1993; Escarabajal y cols., 2000; Sanchis-Segura y cols., 1999a, b). Todos estos trabajos coinciden en que los efectos de las manipulaciones efectuadas sobre la catalasa cerebral fueron paralelos a los efectos sobre la actividad locomotora inducida por el etanol.

Como se comento anteriormente, cuando veíamos el metabolismo cerebral del etanol, también se han utilizado estrategias genéticas para el estudio de la catalasa cerebral y la actividad locomotora. Así, se estudio una cepa de ratones acatalasémicos (C3HA) en comparación con ratones de la cepa "normal" (C3HN) dando como resultado que los que tienen una menor actividad basal de la catalasa (los C3HA) tenían una estimulación de la actividad locomotora inducida por etanol menor que los C3HN. Incluso se muestra un efecto aditivo cuando se combinan las estrategias genéticas y los inhibidores de la catalasa. En este sentido, se estudió el efecto de la administración de AT en los ratones C3HA observándose una mayor disminución de la actividad locomotora (Aragon y Amit, 1993). También se han estudiado diferentes estirpes de ratones con diferentes actividades basales de la catalasa encefálica observándose una correlación positiva entre la actividad de la catalasa y la actividad locomotora inducida por el etanol (Correa y cols., 2004).

Otra estrategia utilizada para el estudio de la implicación de la catalasa encefálica sobre el aumento en la actividad locomotora inducida por etanol ha sido, la utilización de inductores de la enzima catalasa. Estos trabajos ponen de manifiesto que una potenciación de la actividad de la catalasa encefálica correlaciona positivamente con un incremento de la actividad locomotora inducida por etanol. Para la realización de estos estudios se utilizaron como inductores de la 
catalasa un tratamiento crónico con cianamida sódica y una administración aguda de acetato de plomo siete días antes de la administración del etanol (Correa y cols., 1999b, 2000; Sanchis-Segura y cols., 1999c). Estos resultados corroboran la relación entre la modulación de la actividad del compuesto I (sistema catalasa$\mathrm{H}_{2} \mathrm{O}_{2}$ ) y el efecto activador del etanol sobre la actividad locomotora.

Cabe destacar que en todos los estudios que hemos estado viendo la administración del etanol era en ratones naive, lo que significa que no habían tenido ningún contacto previo con el alcohol, por lo que en caso de administraciones crónicas de etanol otros sistemas enzimáticos podrían inducirse y tener relevancia en el metabolismo del etanol. Este es el caso de CYP450 2E1 que tras la administración crónica de alcohol se encuentra inducido, como ya hemos visto, pudiendo llegar ejercer una contribución importante en el metabolismo del etanol (Gill y cols., 1992; Montoliu y cols., 1994; Vasiliou y cols., 2006), lo que implicaría una menor implicación del compuesto I en la oxidación del etanol a acetaldehído en el cerebro.

En este sentido, existen datos que corroboran una implicación del CYP450 2E1 en los efectos relacionados con el etanol, estos datos relacionan un aumento en los niveles y la actividad del CYP450 2E1 con un aumento en la actividad locomotora inducida por etanol (Miquel y cols., 2005; Ledesma y cols., 2014a) . Este sistema metabólico ha sido sugerido como especialmente importante en procesos crónicos (Anandatheerthavarada y cols., 1993; Upadhya y cols., 2000).

Para ahondar en el tema también se ha estudiado la implicación del primer metabolito resultante de la oxidación del etanol, es decir, el acetaldehído. Un estudio utilizó un inhibidor de la ALDH tanto hepática como cerebral, el dietildiocarbonato (DDTC) simultáneamente con la administración de un inhibidor de la ADH el 4-metilpirazol (4-MP). La inhibición de la ALDH tiene un efecto de acumulación del acetaldehído tras la administración de etanol, tanto a nivel central como periférico, por ello se utilizó simultáneamente el inhibidor de la ADH para no permitir la formación de acetaldehído en el hígado y evitar así los efectos que tiene el acetaldehído a nivel periférico (Chao, 1995; Erikson, 2001; Escrig y cols., 2012; Von Wartburg, 1987), pero no impide el metabolismo del etanol en el cerebro ya 
que el principal sistema metabólico para el alcohol en el SNC sería el compuesto I. Con esta estrategia el estudio demostró que la acumulación de acetaldehído en el cerebro mediante la inhibición de la ALDH produce un incremento de la actividad locomotora inducida por etanol en ratones (Escarabajal y Aragon, 2002).

En resumen podemos indicar que en ratones el etanol estimula la actividad locomotora y las manipulaciones al alza o la baja del metabolismo encefálico del etanol modifican los efectos conductuales de esta droga, también podemos indicar que las manipulaciones en la ALDH modifican los efectos conductuales del alcohol, lo que nos lleva a que el acetaldehído esta implicado en las conductas evocadas por el etanol.

\subsubsection{Estudios sobre el consumo voluntario de etanol}

Para el estudio de la participación del metabolismo cerebral del etanol en el consumo voluntario del etanol se han utilizado 3 estrategias distintas, por una parte estudios del llamado "efecto priming" (inyectando alcohol antes del consumo), hay estudios farmacológicos de inhibición de la catalasa y por último estrategias genéticas.

Estudios con ratas de la estirpe UchB (ratas con preferencia por el alcohol) han señalado que una única inyección de alcohol IP provocan un aumento en el consumo voluntario de etanol y este "efecto priming" se puede bloquear con la administración de AT (Tampier y Quintanilla, 2003).

Los estudios farmacológicos de inhibición de la catalasa han demostrado que una administración intraperitoneal (IP) de AT puede inhibir el consumo voluntario de etanol en roedores (Aragon y Amit, 1992; Koechling y Amit, 1994; Rotzinger y cols., 1994). Efecto que es dependiente de la dosis de AT y reversible con el tiempo (Aragon y Amit, 1992; Rotzinger y cols., 1994). Otro estudio relaciona la administración crónica de acetato de plomo con una disminución del consumo voluntario de etanol en ratones de la estirpe C57BL/6J (Correa y cols., 2004). Estos estudios permiten concluir que una reducción en la actividad de la enzima catalasa provoca una disminución en el consumo voluntario de alcohol en roedores. 
Estudios del consumo voluntario de etanol en las cepas de ratones C3HA y C3HN mostraron un patrón de consumo diferente entre ambas cepas, en concentraciones bajas o moderadas de etanol (hasta un $12 \% \mathrm{v} / \mathrm{v}$ ) el consumo fue el mismo en ambas cepas, pero en concentraciones mayores (entre el 13 y el 18\%) los ratones de la cepa C3HA bebían más etanol que los C3HN. Un dato destacable es que los ratones C3HA tienen una preferencia por el alcohol del 50\%, independientemente de la concentración y esto supone un aumento inespecífico en el consumo del alcohol conforme aumentamos la concentración del mismo. Los resultados obtenidos muestran que los ratones acatalasémicos no tienen una preferencia clara por ninguna de las dos sustancias (agua y alcohol), lo que les lleva a beber equitativamente ambas sustancias hasta llegar a concentraciones mayores del 20\%, que producen toxicidad, y hacen que se reduzca el consumo de etanol. Estos datos señalarían a la actividad de la catalasa como mediadora de la regulación del consumo voluntario de etanol (Aragon y Amit, 1993, Aragon y cols., 1992a).

Por otro lado, se han hallado evidencias de una correlación entre el consumo de alcohol y los niveles de catalasa cerebral en estirpes heterogéneas de ratón. Dato que unido a la observación de que la actividad de la catalasa no esta inducida por el consumo de etanol, parece indicar que los niveles de catalasa pudiesen ser un buen predictor del consumo de etanol y no a la inversa (Aragon y cols., 1985). Cabe resaltar otro estudio con ratas que no habían tenido contacto con el etanol que señala que el nivel de actividad peroxidativa de la catalasa sanguínea correlaciona significativamente con los niveles de etanol consumidos voluntariamente con posterioridad (Amit y Aragon, 1988).

Finalmente, los datos de un estudio más reciente en el que se redujo la expresión y la síntesis de catalasa en el cerebro (ShRNA) mediante un vector viral con el que fueron tratadas ratas, mostraron una reducción en la ingesta voluntaria de alcohol (Karahanian y cols., 2011). 


\subsubsection{Estudios sobre la preferencia de lugar condicionada inducida por etanol}

La preferencia de lugar condicionada se basa en nuestro caso en la asociación de un estimulo incondicionado, una droga (el etanol), con un tipo de suelo (por ejemplo un suelo con rejillas o con agujeros), emparejando otro estímulo incondicionado, salina, con un tipo de suelo diferente, para al final de la fase de adquisición (aprendizaje condicionado) realizar un test donde sin presentar el estímulo incondicionado, es decir sin administrar nada a los roedores, se les pone los 2 tipos de suelo a la vez, midiendo el tiempo que pasa en cada tipo de suelo, si pasa más tiempo en el suelo emparejado con etanol diremos que el estímulo incondicionado ha provocado un estimulo condicionado, al evocar las propiedades hedónicas del alcohol en el contexto en el que el etanol fue administrado, estímulo condicionado que provoca una respuesta de aproximación (Prust y cols., 2009). Esto es debido a la asociación de los efectos recompensantes que la droga generó, con el contexto en que se produjo este emparejamiento.

La evaluación de la influencia de la catalasa encefálica sobre la preferencia de lugar inducida por el etanol, experimentos realizados en nuestro laboratorio indican que la preferencia de lugar inducida por etanol puede ser bloqueada por la administración de AT previamente al emparejamiento del estímulo condicionado con etanol (Font y cols., 2008). Esto constataría de nuevo que las memorias emocionales, y los efectos reforzantes y recompensantes del etanol dependen de la actividad de la enzima catalasa en el SNC.

\subsubsection{Efecto de la administración de acetaldehído en diferentes conductas}

\subsubsection{Efectos del acetaldehído sobre la actividad locomotora}

En roedores, el acetaldehído produce estimulación o depresión motora dependiendo de las condiciones experimentales. De este modo, en los estudios en los que el acetaldehído se administra periféricamente se han hallado efectos de supresión de la locomoción (Durlach y cols., 1988; Quertemont y cols., 2004). Una cuestión destacable es que en todos estos estudios se observan los efectos 
depresores durante un periodo muy corto de tiempo, debido posiblemente a la rápida eliminación del acetaldehído por la $\mathrm{ADH}$ hepática. Así, Holtzman y Schneider (1974) observaron los efectos depresores del acetaldehído durante el primer minuto tras una infusión intravenosa de $3 \mathrm{mg} / \mathrm{kg}$ de este compuesto. En otras investigaciones se han encontrado resultados similares, ya que después de inyectar $50 \mathrm{mg} / \mathrm{kg}$ IP de acetaldehído, la depresión motora se puede evaluar durante los primeros minutos de medición (Quertemont y cols., 2004).

Resultados opuestos han sido aportados por estudios en los que el acetaldehído se administra intracerebroventricularmente. En este sentido, se ha demostrado que la administración de esta sustancia por esta vía, es capaz de estimular la locomoción en ratas de forma dosis-dependiente (Correa y cols., 2003). Este efecto estimulante no sólo se observa cuando el acetaldehído es infundido en los ventrículos cerebrales, sino que se produce también cuando se inyecta en la porción reticulada de la sustancia negra (SNr) (Arizzi-La France y cols., 2006). Por último, sabemos que dosis moderadas de acetaldehído incrementan la tasa de respuesta en un protocolo de reforzamiento diferencial de tasas bajas. En este protocolo, la administración intracerebroventricular de esta droga hizo que el número de veces que las ratas presionaban la palanca para obtener el reforzador (el acetaldehído) aumentara, replicando el efecto que la misma administración de etanol producía. Estos datos de nuevo confirman la capacidad del acetaldehído para reproducir el efecto activador que dosis moderadas de etanol producen (Arizzi y cols., 2003).

\subsubsection{Efectos sobre el consumo voluntario del acetaldehído}

La autoadministración de una droga, ya sea ingiriéndola directamente de un recipiente o mediante la ejecución de una respuesta operante, es la manera más directa de analizar los efectos motivadores de una droga. Se ha observado que las ratas aprenden a responder con una palanca si con ello obtienen una infusión intraventricular (Amit y cols., 1977; Brown y cols., 1979; Smith y Amit, 1985) o intravenosa de acetaldehído (Myers y cols., 1982). Además, estos estudios indican que en ratas es más fácil conseguir la autoadministración de acetaldehído que la de etanol, sugiriendo que el acetaldehído sería un reforzador más potente que el 
etanol (Brown y cols., 1979). En la misma línea, recientemente se ha demostrado que el acetaldehído es 1000 veces más potente que el etanol para producir autoinfusión en la parte posterior del ATV, estructura estrechamente relacionada con la capacidad reforzadora del etanol (Rodd-Henricks y cols., 2002).

También se ha observado que las ratas se autoadministran salsolinol en la corteza (shell) del núcleo accumbens (Rodd-Henricks y cols., 2002). Este dato sugiere que la posible acción reforzadora de las tetrahidroisoquinolinas puede estar mediada a través de la actividad del sistema mesolímbico dopaminérgico.

En definitiva, el acetaldehído, al igual que el etanol, también es autoadministrado por los animales, poniendo de manifiesto sus propiedades motivadoras como agente reforzador, capaz de suscitar conductas motivadas.

\subsubsection{Efectos sobre la preferencia de lugar condicionada inducida por acetaldehído}

Dado que el acetaldehído se ha propuesto como posible mediador de algunos de los efectos psicofarmacológicos del etanol, y entre ellos, de los efectos reforzadores, se ha planteado la posibilidad de que el acetaldehído sea capaz de producir preferencia de lugar condicionada.

Esta capacidad del acetaldehído se puso a prueba por primera vez en ratas, a las cuáles se les administraba acetaldehído $(1 \% \mathrm{v} / \mathrm{v})$ o salina en el ventrículo lateral izquierdo. Se registró el tiempo que los animales pasaban en cada lado de la caja de condicionamiento, antes y después de recibir varias infusiones de acetaldehído, comprobando que las infusiones de acetaldehído aumentaban el tiempo que los animales pasaban en el lado de la caja donde se les había infundido esta sustancia (Smith y cols., 1984). Estudios posteriores han replicado estos resultados, obteniendo que la administración intragástrica $(20 \mathrm{mg} / \mathrm{kg})$ de este compuesto es capaz de inducir CPP en ratas (Melis y cols., 2007; Peana y cols., 2008, 2009), sugiriendo así que esta molécula tiene propiedades recompensantes perse.

En otro estudio (Quertemont y De Witte, 2001) se ha demostrado también la capacidad del acetaldehído para producir CPP administrado incluso a dosis altas 
(20-50 mg/kg; IP). Este mismo efecto ha sido replicado es ratas genéticamente seleccionadas por su preferencia innata al alcohol (Quintanilla y Tampier, 2003). Es importante recordar que se ha observado que $20 \mathrm{mg} / \mathrm{kg}$ de acetaldehído IP, es la dosis mínima necesaria para saturar la ALDH de la barrera hematoencefálica y alcanzar el cerebro (Quertemont y cols., 2004).

Otro dato destacable, respecto a la capacidad de esta sustancia de inducir efectos apetitivos condicionados, es la demostración de que el salsolinol (producto derivado de la condensación de dopamina y acetaldehído) produce preferencia de lugar en ratas (Matsuzawa y cols., 2000).

De nuevo pues, volvemos a obtener un paralelismo, entre algunos de los efectos reforzantes que produce el etanol y los que produce el acetaldehído. Así, se ha propuesto que el acetaldehído es capaz de producir memorias emocionales positivas, al igual que ocurre con el alcohol.

En resumen, podemos decir que el acetaldehído es una sustancia reforzadora, independientemente de si su vía de administración es sistémica o central. Sin embargo, el escollo fundamental de los estudios en los que el acetaldehído se administra periféricamente es que, las concentraciones requeridas para que este metabolito alcance el cerebro, están en un rango que difícilmente se alcanzaría en condiciones normales tras la administración de etanol (Heap y cols., 1995; Quertemont y cols., 2005). Por ello, estos estudios, aunque poseen un valor heurístico indudable, son difícilmente generalizables a situaciones de consumo de alcohol. Teniendo en cuenta los datos expuestos hasta ahora, es necesario para la viabilidad de la hipótesis del acetaldehído, discutir los hallazgos experimentales derivados de las manipulaciones del metabolismo cerebral del alcohol. Analicemos pues, cuáles son estos descubrimientos y qué implicación tienen para la hipótesis del acetaldehído. 


\subsubsection{Consecuencias de las manipulaciones del acetaldehído derivado del metabolismo del etanol en los efectos psicofarmacológicos inducidos del etanol}

Como hemos visto hasta ahora, las únicas evidencias acerca de una posible implicación del acetaldehído cerebral derivado del metabolismo encefálico del etanol en las conductas que este evoca eran indirectas, es decir, venían de manipulaciones en las que se alteraba diferentes pasos del metabolismo del etanol y del acetaldehído, por diferentes métodos farmacológicos o bien por métodos genéticos. En los últimos años se han desarrollado nuevos fármacos que permiten secuestrar o desactivar el acetaldehído una vez esta ya ha sido formado, sin necesidad de alterar el metabolismo del etanol, lo que nos permite estudiar la implicación de este metabolito en las conductas inducidas por el etanol. Estas nuevas herramientas son la L-cysteina y la D-penicilamina, que forman productos de condensación con el acetaldehído disminuyendo de esta forma los niveles de este que circulan en sangre (Cohen y cols., 2000; Nagasawa y cols., 1987; Serrano y cols., 2007).

\subsubsection{Secuestro de acetaldehído y estimulación locomotora inducida por etanol}

Un estudio de Font y colaboradores (2005) demostró que la inducción de la locomoción producida por una administración IP de etanol se bloquea en ratones que fueron tratados con anterioridad con distintas dosis de D-penicilamina (37.5$75 \mathrm{mg} / \mathrm{kg}$ ), siendo este efecto reversible en el tiempo y selectivo para el etanol, lo cual descarta un efecto inespecífico de esta sustancia en la locomoción.

Otras investigaciones hallaron resultados parecidos, constatando que la estimulación locomotora que produce una infusión de etanol en el área tegmental ventral, es bloqueada por la administración sistémica de distintas dosis de Dpenicilamina, sugiriendo que esta sustancia puede actuar a nivel central (MartíPrats y cols., 2010)

Estos datos de desactivación del acetaldehído que se genera tras la administración de etanol están en concordancia con los datos de las manipulaciones que inhiben la catalasa encefálica, y como consecuencia los niveles 
de acetaldehído derivados del metabolismo oxidativo del etanol, tiene como consecuencia una disminución de la activación locomotora que produce el alcohol. Poniéndose de manifiesto, una vez más, la participación de este metabolito en los fenómenos conductuales y reforzadores que provoca el etanol.

\subsubsection{Secuestro de acetaldehído y consumo voluntario de etanol}

La D-penicilamina es capaz de reducir el consumo voluntario de etanol en ratas. Se ha encontrado que la administración ICV de D-penicilamina provoca una disminución de la autoadministración de etanol en un paradigma de acceso restringido a esta droga (Font y cols., 2006b). Resultados que han sido interpretados como que la desactivación del acetaldehído que se genera en el cerebro a partir del metabolismo del etanol, tiene como consecuencia un descenso en las propiedades motivadoras del alcohol que llevan a su consumo (Font y cols., 2006b).

Recientemente, en otro estudio se constató que ratas entrenadas en un paradigma "nose poke", en el cual los animales deben dar una respuesta operante para obtener acceso a una solución con etanol, diversas dosis de L-cysteina (20-40 $\mathrm{mg} / \mathrm{kg}$ ) produce un descenso significativo en el número de respuestas que los sujetos dan, y como consecuencia una disminución de la cantidad de etanol que ingieren (Peana y cols., 2010). Una vez más, se pone de manifiesto la relevancia del acetaldehído en los efectos reforzantes del etanol.

\subsubsection{Secuestro de acetaldehído y preferencia de lugar condicionada inducida por etanol}

La preferencia de lugar inducida por el etanol también ha sido testada con estas sustancias (D-penicilamina y L-cysteina) que son capaces de bloquear esta conducta inducida por alcohol. Existen datos de que la administración IP previa de D-penicilamina (50-75 mg/kg) durante los emparejamientos con etanol en la fase de adquisición de la preferencia de lugar condicionada elimina su posterior expresión el día del test (Font y cols., 2006a, 2008). Resultados parecidos se obtienen con dosis de L-cysteina (10-30 mg/kg) (Peana y cols., 2009). También existe un estudio en el que se administra AT y D-penicilamina en el que se 
demuestra que la inhibición de la catalasa unida al secuestro de acetaldehído provoca que no haya preferencia de lugar condicionada por el etanol (Ledesma y Aragon, 2013).El acetaldehído parece tener un papel importante en la formación de las memorias positivas evocadas por el etanol. Lo que confirmaría, una vez más, la hipótesis de que el acetaldehído pudiera ser el mediador de los efectos recompensantes del etanol, como mínimo en los paradigmas en los que ha sido evaluado.

\subsection{LA MODULACIÓN DE LOS NIVELES DE PERÓXIDO DE HIDRÓGENO ENCEFÁlICOS COMO ESTRATEGIA PARA EL ESTUDIO DEL PAPEL DEL COMPUESTO I EN LOS EFECTOS REFORZANTES DEL ETANOL}

Hasta ahora hemos discutido datos que apoyan de un modo convergente la idea de que el acetaldehído es mucho más que un metabolito activo del etanol. El acetaldehído, a través de sus acciones en diversos sistemas de neurotransmisión, produce efectos conductuales y fisiológicos. Además, tal y como hemos visto no sólo produce acciones y efectos por si mismo sino que puede explicar parte de los cambios de conducta inducidos por el etanol.

El descubrimiento del metabolismo central del etanol supuso una nueva puerta en el estudio de la implicación del acetaldehído en las conductas inducidas por etanol. Pero la dificultad existente para medir este compuesto tras el consumo de alcohol continua siendo un gran hándicap en la hipótesis del acetaldehído. Cabe destacar también que al no haber alternativas farmacológicas a las que ya se han usado clásicamente en este campo, han creado críticas debido a los posibles efectos secundarios que pueden producir la mayoría de las sustancias utilizadas o por su falta de selectividad en cuanto a la inhibición del metabolismo de etanol en el cerebro (Quertemont y cols., 2005). Por lo tanto se requiere el uso de nuevas herramientas y aproximaciones para poder continuar avanzando en su estudio, abordándolo desde diferentes perspectivas. Una última manipulación indirecta realizada hasta la fecha, ha consistido en alterar los niveles de producción de peróxido de hidrógeno y más recientemente el secuestro mediante sustancias de el $\mathrm{H}_{2} \mathrm{O}_{2}$. 
El estudio del papel de la actividad del compuesto I en diferentes conductas inducidas por etanol, mediante la modificación de la cantidad de peróxido de hidrógeno presentes en el medio, facilitando o dificultando así la formación del sistema catalasa- $\mathrm{H}_{2} \mathrm{O}_{2}$ (compuesto I) que se requiere para formar acetaldehído a nivel central.

En el organismo se forma peróxido de hidrógeno a partir principalmente de un proceso fisiológico conocido como estrés oxidativo que se caracteriza por la ruptura de la homeostasis oxidativa, en principio esto podría ser debido a las acciones de los radicales libres o especies reactivas de oxígeno, entre las que se encuentran el anión superoxido $\left(\mathrm{O}_{2}^{-}\right)$, el radical hidroxilo $(\mathrm{OH})$ y el propio peróxido de hidrógeno (Gonzalez-Fraguela, 2000). Estas moléculas son generadas por reacciones bioquímicas dentro del metabolismo celular normal. Por ejemplo, una de las fuentes principales de estos radicales libres es la propia respiración, dado que el oxígeno consumido se transforma en radicales libres con una tasa entre el 1 y el 3\%. Bajo condiciones particulares, como la inhalación de oxígeno en altas concentraciones o hiperoxia, se ha constatado un aumento en el porcentaje de radicales libres que se forman (Gonzalez-Fraguela, 2000). Uno de los efectos de la hiperoxia mejor estudiados es la producción de peróxido de hidrógeno.

Varios han sido los trabajos realizados con el fin de evaluar las consecuencias funcionales derivadas del aumento de los niveles de $\mathrm{H}_{2} \mathrm{O}_{2}$ disponibles en el SNC, sobre la actividad del compuesto I y la actividad locomotora inducida por etanol en ratones. Se han llevado a cabo básicamente 2 manipulaciones para ver el efecto de un aumento del peróxido de hidrógeno disponible en el encéfalo: por un lado la exposición a ambientes enriquecidos en oxígeno $\left(99.5 \% \mathrm{O}_{2}\right)$ durante periodos de tiempo superiores a los 30 minutos que aumentó la actividad de la catalasa encefálica en ratones (Pastor y cols., 2002) y que además como consecuencia de este aumento de la actividad de la enzima produce una potenciación de la estimulación de la locomoción inducida por el etanol. Los otros estudios se realizaron utilizando el ácido 3-nitropropionico (3-NPA), un compuesto que tiene la capacidad de aumentar la concentración de radicales libres, entre ellos el peróxido de hidrógeno (Alexi y cols., 2000) y la actividad de la catalasa (Binienda y 
cols., 1998), también se ha demostrado su capacidad para aumentar la actividad locomotora inducida por etanol en ratones (Manrique y cols., 2006). Esta estimulación locomotora puede ser prevenida mediante la administración de Lcarnitina, un potente antioxidante (Binienda y cols., 1998; Manrique y cols., 2006) que actuaría reduciendo la cantidad de especies reactivas de oxígeno en los organismos. Todo esto nos lleva a pensar que además de la actividad de la catalasa encefálica, la disponibilidad de peróxido de hidrógeno en el SNC también es un factor determinante como mínimo en la estimulación locomotora que induce una inyección aguda de etanol. Lo que llevaría a considerar al $\mathrm{H}_{2} \mathrm{O}_{2}$ como el factor limitante para la actividad peroxidátiva de la catalasa, que estaría determinando la producción de acetaldehído tras la administración de etanol, y como consecuencia directa, la estimulación de la actividad locomotora que provoca la administración de alcohol. Dicho de otra forma, teniendo en cuenta que el peróxido de hidrógeno es el cosubstrato indispensable para que la catalasa forme el compuesto I y este sea capaz de metabolizar el etanol en el sistema nervioso central, un aumento en la concentración de $\mathrm{H}_{2} \mathrm{O}_{2}$ disponible tendría como resultado un aumento en la producción de acetaldehído debido a un incremento de compuesto I que se formaría, cuya consecuencia, tal y como sucede con otras manipulaciones que aumentan la actividad del sistema catalasa- $\mathrm{H}_{2} \mathrm{O}_{2}$, potenciaría los efectos psicomotores del alcohol.

Hasta ahora sólo hemos observado el efecto que tiene el aumento en los niveles de peróxido de hidrógeno en la locomoción inducida por etanol, dejando un vacío acerca de las consecuencias funcionales que pueda tener el aumento del $\mathrm{H}_{2} \mathrm{O}_{2}$ endógeno en otras conductas evocadas por el alcohol, así como el posible efecto que pudiera tener una reducción de este.

Para reducir los niveles de peróxido de hidrógeno se han utilizado 2 herramientas farmacológicas: por una lado el ebselen, y por otro el ácido alpha lipoico (1,2-dithiolane-3-pentaoic acid; LA). El LA ha demostrado ser un cofactor esencial que esta presente en las mitocondrias y tiene la función de eliminar radicales libres procedentes del estrés oxidativo (Somani y cols., 2000). El uso de este compuesto en el estudio de las conductas inducidas por etanol se debe a que 
una inyección aguda de $50 \mathrm{mg} / \mathrm{kg}$ de ácido alpha lipoico es capaz de incrementar la tasa de eliminación de peróxido de hidrógeno, mediante el aumento de la actividad de la glutatión peroxidasa en varias regiones cerebrales en ratas, siendo además capaz de secuestrar $\mathrm{H}_{2} \mathrm{O}_{2}$ por si mismo (Bilska y cols., 2007). Los datos obtenidos en estudios realizados en el campo del etanol revelan que el LA mediante el secuestro y eliminación del $\mathrm{H}_{2} \mathrm{O}_{2}$ es capaz de reducir la estimulación motora inducida por etanol en ratones, no afectando a la estimulación motora inducida por otras drogas (Ledesma y Aragon, 2012). Esta sustancia también provoca una disminución de la ingesta voluntaria de etanol de manera dosisdependiente en ratones (Ledesma y cols., 2014b). El ácido alpha lipoico evita la adquisición y el recondicionamiento de la preferencia de lugar inducida por el etanol, pero no modifica la preferencia de lugar inducida por morfina o cocaína (Ledesma y Aragon, 2013). Así mismo, esta sustancia protege de la inhibición del compuesto I que ejercen el AT y la cianamida sobre la catalasa encefálica (Ledesma y cols., 2014b). Con todo esto podemos resumir que el LA mediante el secuestro y la eliminación del peróxido de hidrógeno disponible en el SNC provoca una disminución en la formación del compuesto I, disminuyendo de esta forma la producción de acetaldehído derivado del metabolismo del etanol.

Por su parte el ebselen aumenta la tasa de eliminación del peróxido de hidrógeno de manera similar a la glutiation peroxidasa, reduciendo los niveles de $\mathrm{H}_{2} \mathrm{O}_{2}$ que se generan en el sistema nervioso central (Mairiorino y cols., 1988, Parham y Sies, 2000). Partiendo de estas premisa se estudio los efectos de esta sustancia tanto en la locomoción inducida por etanol como en la ingesta voluntaria de alcohol. El ebselen disminuyo la actividad locomotora inducida por etanol sin afectar a la locomoción inducida por otras drogas (Ledesma y cols., 2012). La ingesta voluntaria de etanol se vio reducida tras la administración de ebselen (Ledesma y cols., 2014b). Y por último se demostró que el ebselen protegió al compuesto I de su inhibición por el AT y la cianamida (Ledesma y cols., 2014b).

En resumen hay muchos datos que señalan la implicación del sistema catalasa- $\mathrm{H}_{2} \mathrm{O}_{2}$ cerebral, así como la participación del acetaldehído formado centralmente en la modulación de las conductas inducidas por el etanol. 


\subsection{LA MONOAMINO OXIDASA}

La monoamino oxidasa (MAO) es una enzima de la familia de las flavoproteínas que cataliza la desaminación oxidativa de las monoaminas (neurotransmisores, neuro-moduladores e incluso hormonas) a su aldehído correspondiente. La reacción tipo la podemos ver en el Esquema 1. Esta reacción necesita que la MAO este unida mediante un enlace covalente al cofactor flavín adenín dinúcleotido (FAD) y sucede en tres pasos (Bortolato y Shih, 2011). Estos pasos son:

a. Tras la formación del aducto MAO-FAD, el cofactor se reduce a su forma hidroquinona $\left(\mathrm{FADH}_{2}\right)$, mientras que el sustrato (la amina) es convertida en su correspondiente imina (Esquema 2a).

b. La imina es espontáneamente hidrozilada formándose amonio y el correspondiente aldehído (Esquema 2b).

c. La forma hidroquinona del cofactor $\left(\mathrm{FADH}_{2}\right)$ es reoxidada con oxígeno molecular $\left(\mathrm{O}_{2}\right)$ formándose peróxido de hidrógeno $\left(\mathrm{H}_{2} \mathrm{O}_{2}\right)$, Esquema 2c. Esta es la reacción limitante de todo el proceso enzimático.

$$
\mathrm{RCH}_{2} \mathrm{NH}_{2}+\mathrm{H}_{3} \mathrm{O}^{+} \longrightarrow \mathrm{RCHO}+\mathrm{NH}_{4}^{+}+\mathrm{H}_{2} \mathrm{O}_{2}
$$

Esquema 1. Reacción de desaminación de aminas endógenas (tomado de Bortolato y Shih, 2011).

Los sustratos endógenos de la monoamino oxidasa son variados incluyendo importantes neurotransmisores como: la serotonina (5-hydroxitriptamina, 5-HT), la dopamina (DA), la noradrenalina (NA) y la adrenalina (A), así como numerosas aminas traza o rastro entre las que se encuentran la tiramina, triptamina, 2feniletilamina (PEA), octopamina y 3-yodotironamina. La función de la MAO en la homeostasis de estos compuestos es de vital importancia para modular la regulación neuroendocrina del sistema nervioso central y muchos de los órganos periféricos (Bortolato y Shih, 2011). 


\section{Enz-FAD $+\mathrm{RCH}_{2} \mathrm{NH}_{2} \longrightarrow$ Enz-FADH ${ }_{2}+\mathrm{RCH}=\mathrm{NH}$ $\mathrm{RCH}=\mathrm{NH}+\mathrm{H}_{3} \mathrm{O}^{+} \longrightarrow \mathrm{RCHO}+\mathrm{NH}_{4}^{+}$ Enz-FADH ${ }_{2}+\mathrm{O}_{2} \longrightarrow$ Enz-FAD $+\mathrm{H}_{2} \mathrm{O}_{2}$}

Esquema 2. Las tres fases en que se desarrolla la reacción de desaminación de las aminas endógenas (tomado de Bortolato y Shih, 2011).

Los aldehídos producidos por la monoamino oxidasa son productos tóxicos por lo que es necesario convertirlos en metabolitos menos dañinos, esto es realizado por medio de la $\mathrm{ALDH}$, por la aldehído reductasa e incluso por la ADH, produciendo distintos metabolitos dependiendo del enzima utilizado (Bortolato y Shih, 2011).

La función que la MAO desempeña en la regulación del estado redox intracelular en las neuronas y otras células es crítico. De hecho, uno de los subproductos de la reacción mediada por la MAO es el peróxido de hidrógeno que es un potente oxidante que puede desencadenar la formación de aniones superoxido $\left(\mathrm{O}_{2}^{-}\right)$, y otros reactivos oxigenados, los cuales pueden producir daños en la mitocondria y el citoplasma celular. En condiciones fisiológicas normales este potencial redox esta manteniendo un equilibrio gracias a las enzimas antioxidantes, como la superoxido dismutasa, catalasa y glutatión peroxidasa; sin embargo la presencia de grandes cantidades de amonio han demostrado ser responsables de la disminución de la actividad de estos sistemas enzimáticos provocando la formación de estos radicales superoxidativos (Kosenko y cols., 1997). Teóricamente, un exceso de especies oxidativas en el SNC provocaría daños que implicarían la muerte de neuronas y células glía. Estos mecanismos son la base de la teórica implicación de la MAO en ciertas enfermedades neurodegenerativas, como el Parkinson y las demencias (Danielczyk y cols., 1988). En esta línea se ha constatado un incremento en la actividad de la MAO-B en plaquetas en pacientes con la enfermedad de Alzehimer, proponiendo que este puede ser un biomarcador para el diagnostico precoz de esta enfermedad (Grünblatt y cols., 2005). 
Por último, la monoamino oxidasa cumple un rol principal en la degradación de aminas xenobioticas primarias, secundarias y algunas terciarias; lo que adquiere una importancia en la prevención de su neurotoxicidad en el corazón y el SNC. Un ejemplo bien descrito de esto sería la llamada "reacción del queso" que consiste en una crisis vasoconstrictiva, que puede llegar a ser mortal, causada por la absorción de aminas simpatomiméticas de la comida (queso, vino, etc.) tras la administración de inhibidores no selectivos de la MAO (Anderson y cols., 1993).

\subsubsection{Isoenzimas de la monoamino oxidasa}

Se han descrito dos isoenzimas de la MAO, nombrados como A y B (MAO-A, MAOB), los cuales a pesar de tener una estructura similar difieren en la preferencia por los sustratos, la selectividad de sus inhibidores, distribución anatómica y su función en la regulación conductual.

Los isoenzimas de la monoamino oxidasa se descubrieron a través de los datos experimentales de distintos inhibidores que poseían efectos neuroquímicos divergentes. De hecho, la MAO-A es inhibida selectivamente por dosis bajas de clorgilina (Johnston, 1968), mientras que la MAO-B se inhibe con concentraciones nanomolares de deprenil (Knoll y Magyar, 1972).

Estudios posteriores mostraron que la MAO-A tiene una gran afinidad por la 5-HT (unas 120 veces mayor que la MAO-B) y en menor medida por la noradrenalina; contrastando con la preferencia de la MAO-B por la 2-feniletilamina y la benzilamina. La metabolización de la dopamina, triptamina y tiramina están mediadas por ambos isoenzimas, aunque hay que tener en cuenta que la contribución relativa de cada isoenzima parece ser muy variable, dependiendo de las especies y los tejidos que se consideren. Como ejemplo de esto último, el metabolismo de la DA se realiza preferentemente por la MAO-A en roedores y por la MAO-B en humanos y otros primates (Garrik y Murphy, 1980; Fornai y cols., 1999). Los sustratos que metabolizan preferentemente cada uno de los isoenzimas no son excluyentes, de hecho, en ausencia de un isoenzima el otro puede metabolizar una cierta cantidad de sus sustratos no preferentes (Chen y cols., 2004). Este mecanismo de compensación parcial esta ampliamente estudiado 
mediante los cambios neuroquímicos que experimentan los ratones con deficiencia en cualquiera de los isoenzimas y señalan la significancia fisiológica de la presencia de ambos isoenzimas en los seres vivos. Con la clonación de los genes de la MAO-A y la MAO-B se obtuvo la prueba irrefutable de la existencia de ambos isoenzimas (Bach y cols., 1988). Cabe destacar que ambos genes comparten aproximadamente un $70 \%$ de secuencia y una organización intron-exon idénticas, con 14 exones y 15 intrones. Estos hallazgos han llevado a la hipótesis de que ambos genes provienen de la duplicación de un mismo gen (Grimsby y cols., 1991). Lo que estaría en concordancia con la existencia de una única isoforma de la monoamino oxidasa en células eucarióticas primarias (Schiling y Lerch, 1995), invertebrados (Boutet y cols., 2004) y peces teleósteos (Chen y cols., 1994; Setini y cols., 2005; Anichtchik y cols., 2006). Por otro lado, la presencia de dos isoenzimas puede constatarse en los anfibios anuros (Kobayashi y cols., 1981), en ranas la MAO-A es predominante en la fase larvaria mientras que hay un aumento de la expresión de la MAO-B a través de la metamorfosis (Nicotra y Senatori, 1988), lo que señalaría la posibilidad de que la duplicación del gen pudiera haber sido una selección natural para tratar de mantener la homeostasis redox en respuesta al desarrollo de la respiración pulmonar y la consecuente aparición de radicales libres altamente oxidantes. Cabe destacar que la MAO-B tiene una mayor $\mathrm{K}_{\mathrm{m}}$ (aproximadamente $250 \mu \mathrm{M}$ ) lo que implica una menor afinidad por el $\mathrm{O}_{2}$ que la MAO-A (aproximadamente 6 $\mu \mathrm{M}$ ) (Edmonson y cols., 2004). Teniendo en cuenta el papel que la monoamino oxidasa realiza en la regulación de la función cardiaca, el desarrollo de los isoenzimas con preferencia por diferentes sustratos pudo ser una forma de contrarrestar los nuevos problemas surgidos de la vida terrestre sobre la circulación sanguínea.

Por lo que se refiere a su localización, ambos isoenzimas se encuentran en la mayoría de los tejidos, tan sólo la MAO-A es característicamente abundante en la placenta y los fibroblastos, por el contrario la MAO-B es el único isoenzima presente en las plaquetas y los linfocitos (Bond y Cudall, 1977; Donnelly y Murphy, 1977). LA MAO-A y la MAO-B se encuentran presentes en la mayoría de las regiones cerebrales, aunque existen áreas que disponen de un único isoenzima. La MAO-A se encuentra principalmente en las neuronas dopaminérgicas y 
noradrinérgicas, mientras que la isoforma B de la monoamino oxidasa es el único isoenzima que hay en el cuerpo celular de las neuronas serotonérgicas (Konradi y cols., 1989). Esta localización esta cuestionada, ya que la 5-HT es metabolizada principalmente por la MAO-A en vivo. Para salvar esta aparente contradicción, esta la hipótesis de que la proteína de la MAO-A puede ser trasladada del interior del cuerpo celular y segregada en los axones terminales (bortolato y cols., 2010); hipótesis apoyada por el descubrimiento de que la MAO-B esta ausente de las mitocrondias de los axones terminales (Arai y cols., 2002), también esta constatada la presencia de ácido ribonucleico mensajero (ARNm) de la MAO-A en las células serotonérgicas (Luque y cols., 1995, 1996; Jahng y cols., 1997; Filipenko y cols., 2002; Whibley y cols., 2010). La compartimentación propuesta puede facilitar la degradación especifica de la 5-HT en los terminales sinápticos; Además, la expresión de la MAO-B en el cuerpo celular de las neuronas serotonérgicas tendría funciones protectoras para la serotonina.

\subsubsection{Inhibición de la monoamino oxidasa}

El desarrollo de los inhibidores de la monoamino oxidasa comenzó por el descubrimiento casual de efectos antidepresivos en pacientes que eran tratados con iproniazida (un agente anti tuberculosis) (Fox y Gibas, 1953). Este hallazgo junto a la constatación de que la iproniazida es un potente inhibidor de la MAO (Zeller y Barsky, 1952), condujo al desarrollo de otros inhibidores como la fenelzina, también basada en la hidracina. Tras comprobarse que los inhibidores de la MAO basados en la hidracina provocaban toxicidad en el hígado se establecieron nuevos tipos de inhibidores no selectivos: tranilcipromina, que inhibe ambas isoformas; selectivos e irreversibles (clorgilina, inhibe la isoforma A; deprenil, inhibe la $\mathrm{MAO}-\mathrm{B}, . .$. ); selectivos y reversibles (son todos inhibidores de la MAO-A, brofaromina, moclobemida,...); inhibidores de la MAO-colín esterasa (ladostigil, que inhibe la A y la B) (Bortolato y cols., 2008).

Otro efecto indeseable de los inhibidores no selectivos de la MAO, es la llamada "reacción del queso", tras el consumo de queso, vino u otros alimentos fermentados, ricos en tiramina y aminas simpatomiméticas (Brown y cols., 1989). 
La ausencia del metabolismo intestinal mediado por la MAO-B provoca que estos compuestos sean absorbidos y entren en el flujo sanguíneo, induce un aumento de la liberación de noeradrenalina en la medula, que activa el sistema simpático y en ausencia de metabolismo mediado por la MAO-A causa un repentino incremento de la presión sanguínea. Todo esto propulso la búsqueda de inhibidores selectivos de la MAO-A y la MAO-B. Como consecuencia del desarrollo de inhibidores de la MAO-B, como el deprenil, revelaron una eficacia de estos compuestos en terapias de la enfermedad de Parkinson (Bortolato y cols., 2008).

Los inhibidores de la MAO se han utilizado con distinto éxito en: depresión y desordenes del ánimo, desordenes de ansiedad, déficit de atención e hiperactividad, enfermedad de Parkinson, enfermedad de Alzheimer y otras enfermedades neurodegenerativas (esclerosis lateral amiotrofica y enfermedad de Huntington).

\subsubsection{Desactivación genética de la MAO}

A pesar de que se distinguieron las isoformas de la monoamino oxidasa por su afinidad para bajas dosis de inhibidores, hay estudios que muestran que ni los inhibidores de la A o la B son completamente selectivos en dosis altas, las cuales pueden ser necesarias para asegurar la total inactivación de cada isoenzima. Para obviar esto se han desarrollado numerosas líneas de ratones transgénicos con mutaciones "sin sentido" para cada isoforma de la MAO. La caracterización de los fenotipos de estos ratones han contribuido a conocer el rol de la monoamino oxidasa en la regulación de las conductas y funciones cerebrales (Bortolato y cols., 2008).

La primera cepa de ratones "Knock out (KO)" fueron creados para experimentar la función de la MAO-A en vivo se obtuvo mediante la inserción dirigida de un interferón en el exón 2 del gen de la MAO-A (Cases y cols., 1995). Debido a la que los genes de ambos isoenzimas están en el gen $\mathrm{X}$, los machos homicigoticos de esta cepa muestran un aumento significativo de los niveles cerebrales de 5-HT y NA y un menor incremento de la DA. La conducta característica que más llama la atención en estos ratones es un aumento de los 
rasgos agresivos, medido tanto en un paradigma residente-intruso (Cases y cols., 1995; Shih y cols, 1999), como en encuentros con sus compañeros de habitáculo. La neuroquímica subyacente en la agresividad de los ratones MAO-A KO no esta del todo esclarecida, aunque debe reflejar componentes del desarrollo. De hecho, la administración de clorgilina no provoca un aumento de la agresividad en adultos, mientras que inyecciones crónicas con clorgilina en estados perinatales provoca una disminución en la latencia de ataque en ratas adultas (Mejia y cols., 2002). Este efecto correlaciona con la observación de que los cachorros de los MAO-A KO muestran concentraciones de serotonina 9 veces mayores que los ratones de la cepa original (wild type, WT) de la misma edad (Cases y cols., 1995), mientras que esta diferencia es tan solo dos veces mayor en los animales adultos.

Los ratones MAO-A KO muestran una mayor memoria de los episodios aversivos relacionados con el miedo que los WT, incluyendo la respuesta de freezing (congelación) ante un shock eléctrico en las patas (Kim y cols., 1997) la memoria retentiva en el condicionamiento de evitación pasiva (Dubrovina y cols., 2006).

En general, se produce un aumento de la resistencia a los efectos de los estresores medioambientales inducido por la deficiencia de la MAO-A en el cerebro; por ejemplo, los ratones MAO-A KO muestran una típica reducción en el tiempo que pasan inmóviles en la prueba de natación forzada (Cases y cols., 1995), la cual es un modelo animal validado de la depresión (Cryan y cols., 2001). Los MAO-A KO difieren de los WT en la prueba de suspensión de la cola, aunque el tiempo total de inmovilidad no fue diferente entre los dos grupos de animales (Scott y cols., 2008), si que fue diferente en el tipo de modalidad de activación motora, los MAO-A KO tuvieron un número significativamente mayor de contorsiones e intentos de alcanzar el garfio del que están colgados que los WT. También muestran una reducción de la respuesta de sobresalto acústico (Cases y cols., 1995). Todo ello esta en concordancia con las evidencias halladas en las que los ratones MAO-A KO muestran respuestas endocrinas atenuadas frente a potentes estresores como la restricción de movimientos, baja temperatura, privación de agua prolongada y estrés crónico (Popova y cols., 2006). 
En general, estos resultados sugieren que los ratones MAO-A KO deben tener una discapacidad en la percepción de estresores externos y en la mediación de las respuestas adaptativas al estrés, lo que puede subyacer en el incremento de las conductas agresivas. La evaluación psicológica de los rasgos agresivos en el síndrome de Brunner, un desorden genético causado por una mutación sin sentido del gen de la MAO-A, revela que los sujetos afectados responden a estímulos relativamente triviales de duelo con agresiones impulsivas y actos violentos (Brunner y cols., 1993). Estas alteraciones pueden ser debidas auna desregulación sensorial, como sugiere la desorganización de la corteza somatosensora (Cases y cols., 1995). Cabe resaltar que esta alteración puede provocar el incremento de la agresión mostrado por los MAO-A KO. Es más, la administración del inhibidor de la síntesis de 5-HT p-clorofenilalanina a los ratones MAO-A KO revoca los efectos estructurales y las conductas agresivas en adultos (Cases y cols., 1996). Más indicios de la posible relación entre las alteraciones de la corteza somatosensora y la agresión viene de un trabajo de Chen y cols. (2007) que observaron que la alteración en la corteza somatosensora fue revocada por un "Knock in" de la MAOA, especifico en el cerebro anterior de los ratones MAO-A KO.

En el otro extremo, los ratones MAO-B KO (ratones con deficiencia en la MAO-B) muestran un incremento en los niveles cerebrales de PEA, pero no de 5HT, NA ni DA. Esta alteración no ha sido asociada con cambios significativos en los patrones de locomoción en el campo abierto ni el laberinto elevado en cruz, pero si que reducen el tiempo de inmovilidad en la prueba de natación forzada, en una o repetidas ocasiones (Grimsby y cols., 1997).

Mientras bajos niveles de MAO-B han sido repetidamente asociados con aumentos de las respuestas a la novedad, extraversión y conductas desinhibidas, los datos obtenidos con ratones MAO-B KO no confirmarían estos rasgos. A modo de ejemplo, los ratones MAO-B KO no presentan diferencias con los WT en el consumo o la preferencia por la nicotina (Lee y cols., 2004). Una de las razones subyacentes a estas discrepancias pudiera ser que mientras la MAO-B en humanos tiene un papel importante en la degradación de la DA, este papel en el metabolismo de la DA es llevado a cabo principalmente por la MAO-A en roedores (Garrick y 
Murphy, 1980). Es más, los ratones MAO-B KO no muestran alteraciones en la liberación ni en la recaptación de la DA (Chen y cols., 1999).

Los cambios fenotípicos que se observan en los ratones MAO-B KO son mucho más sutiles que los observados en los MAO-A KO, teniendo en cuenta que el PEA esta presente en el cerebro en muy bajas concentraciones (Bunzow y cols., 2001; Berry, 2004) y se piensa que realiza funciones similares a las anfetaminas en la modulación de la neurotransmisión y la señalización de la DA y la NA (Sabelli y cols.,1975; Risner y Jones, 1977). La PEA se sintetiza junto a la DA por medio de la L-DOPA descarboxilasa (Sabelli y cols.,1975; Risner y Jones, 1977).

Las ultimas líneas de investigación han indicado que la PEA es el principal activador de los receptores asociados a las amino trazas 1 (TAAR1, Xie y Miller, 2008; Wolinski y cols., 2007), el cual, a su vez, modula las señalizaciones catecolaminérgicas (Wolinski y cols., 2007). Curiosamente, los ratones MAO-B KO muestran varias diferencias que estarían unidas por los elevados niveles de PEA, por ejemplo, muestran una disminución de la hiperlocomotricidad inducida por anfetamina (Yin y cols., 2006), así como, alteraciones en la distribución del flujo sanguíneo cerebral (Scremin y cols., 1999). La PEA sería posiblemente causante de la reducción de los receptores de la dopaminérgicos D2 y la sensibilidad aumentada de los receptores D1 en el estriado de estos roedores (Chen y cols., 1999).

La esquizofrenia, obsesión, déficit de atención por hiperactividad y la dependencia a las metanfetaminas han atraído la atención ya que pudieran ser de alguna manera influenciadas por la PEA y TAAR1 (Wolinski y cols., 2007). Los ratones MAO-B KO serían el único modelo para el estudio de los efectos a largo plazo de las consecuencias de niveles altos de PEA tanto en las conductas como las funciones cerebrales.

\subsubsection{Efectos estudiados de la inhibición de la MAO en conductas inducidas por etanol}

Estudios con ratas mostraron que varios inhibidores de la MAO, que incluían tanto de la isoforma A como de la B y no selectivos, provocaron una disminución en la 
ingesta de etanol en al autoadministración de etanol al 10\% (v/v) con acceso libre a dos palancas en un paradigma operante, los animales debían pulsar la palanca para obtener el fluido (Cohen y cols., 1999). Otro estudio comparo los resultados de varios inhibidores irreversibles (clorgilina de la MAO-A, deprenil de la MAO-B y fenilzina de ambas isoformas) con un inhibidor reversible de la MAO-A (BW A616U), en todos los casos se redujo la cantidad de etanol ingerida excepto con el inhibidor irreversible de la MAO-B (deprenil) en esta caso el paradigma fue también de libre elección pero sin ser operante (Mega y cols., 2002). 



\section{OBJETIVOS e HIPÓTESIS}

El objetivo general de esta tesis doctoral consiste en evaluar las consecuencias de la reducción de peróxido de hidrógeno producido en el sistema nervioso central por la desaminización de las aminas biogénicas, realizado por la monoamino oxidasa, mediante la administración de inhibidores irreversibles de la MAO-A y la MAO-B (clorgilina y deprenil, respectivamente) sobre distintas conductas inducidas por el etanol. Para la consecución de este objetivo, llevamos a cabo tres fases experimentales diferentes en las que investigamos los efectos de la administración de clorgilina y deprenil en la estimulación locomotora inducida por etanol, la sensibilización motora inducida por el alcohol etílico y el consumo voluntario de etanol que evoca esta droga.

Para la primera fase experimental escogimos la estimulación locomotora inducida por el etanol como variable dependiente por diversos motivos. El principal motivo es que este paradigma tiene la ventaja de no depender de la voluntariedad del sujeto ya que la droga es administrada por el investigador, permitiéndonos fijar y determinar los parámetros de la eficacia farmacológica de las manipulaciones empleadas.

La hipótesis de trabajo a resolver dentro de este bloque experimental es que, la clorgilina y el deprenil, al reducir los niveles de $\mathrm{H}_{2} \mathrm{O}_{2}$ formados en el SNC, llevarán a una menor formación del compuesto I y, consecuentemente, se metabolizará menos etanol, lo cual llevará a una disminución en la producción de acetaldehído cerebral. Esto tendrá como resultado final un bloqueo de la estimulación locomotora inducida por etanol ya que se reducirá la propiedad activadora que posee esta sustancia como reforzador.

Los efectos que sobre la sensibilización motora inducida por etanol ejercen los inhibidores de la MAO (A clorgilina, B deprenil) fueron escogidos para evaluar la administración crónica de etanol. Este paradigma nos permite conocer si los efectos que ejercen la clorgilina y el deprenil sobre la estimulación motora dependen del número de veces que se administra el etanol. 
En este caso la hipótesis de trabajo sería básicamente la misma que la explicada para la primera fase. Esperando como resultado final que se bloquee la sensibilización motora inducida por etanol.

En la ultima fase elegimos el paradigma de consumo de etanol con acceso restringido ya que este nos permite evaluar la capacidad reforzadora del etanol a través del registro de la fase consumatoria de esta sustancia. Pudiendo investigar los aspectos motivadores de esta droga.

La hipótesis para esta tercera fase seria comprobar si, al igual que la estimulación locomotora inducida por etanol, la reducción de la producción de peróxido de hidrógeno, que provocan los inhibidores de la monoamino oxidasa (A y B), producen una disminución de la cantidad de etanol ingerido por los ratones. El mecanismo de acción sería el mismo que en las fases anteriores, una menor producción de $\mathrm{H}_{2} \mathrm{O}_{2}$ en el SNC reducirá la actividad de la catalasa, ya que no podrá formar el compuesto I, lo que reducirá la producción de acetaldehído disminuyendo el consumo de alcohol etílico.

Nuestra Hipótesis principal es que la catalasa necesita tener como cosubstrato al peróxido de hidrógeno para poder formar el compuesto I y ser capaz de metabolizar el etanol en acetaldehído en el sistema nervioso central. Se conocen varias fuentes de peróxido de hidrógeno en el SNC, pero ninguna ha sido estudiada como posible fuente principal de $\mathrm{H}_{2} \mathrm{O}_{2}$ implicada en la formación del compuesto I. Por ello proponemos que la monoamino oxidasa, ya que produce peróxido de hidrógeno como subproducto de la reacción de desaminizacion de las aminas biogénicas, pudiera ser la fuente principal del $\mathrm{H}_{2} \mathrm{O}_{2}$ en el SNC. Dado que muchos de los efectos conductuales que el etanol ejerce lo hace a través del acetaldehído formado centralmente por el sistema catalasa- $\mathrm{H}_{2} \mathrm{O}_{2}$, esperamos que una reducción de los niveles de peróxido de hidrógeno, como resultado de la inhibición de la MAO, formado en el SNC provoque una menor formación de acetaldehído, ya que se formará menos compuesto I, tras la administración de etanol. Lo que provocará un bloqueo de la estimulación locomotora inducida por el alcohol etílico, la sensibilización motora al mismo o la ingesta voluntaria de etanol. 
En resumen, proponemos que la reducción en la formación de peróxido de hidrógeno que provocaran los inhibidores de la MAO (A y B) en el SNC tendrá como consecuencia una menor formación de compuesto I, por lo tanto una menor formación de acetaldehído, que reducirá los efectos que el etanol produce sobre la locomoción y su consumo voluntario. 



\section{MATERIALES Y MÉTODOS}

\subsection{SUJETOS}

Dos estirpes diferentes de ratones fueron utilizadas para la realización de estos experimentos. Para los experimentos de actividad locomotora, sensibilización y los procedimientos bioquímicos se utilizaron ratones de la estirpe Swiss (IOPS Orl) albino mice, adquiridos de la empresa Janvier Spain S.A. (Barcelona, España) que llegaron al laboratorio con 4 semanas de edad. Esta estirpe fue elegida por su sensibilidad a los efectos estimuladores del etanol (Camarini y cols., 2000). Los animales fueron alojados en grupos de tres individuos en jaulas de material plástico y lechos de serrín con comida para roedores (Panlab S.L., España) y agua potable disponibles ad libitum.

Para los experimentos de ingesta voluntaria de fluidos la estirpe seleccionada fue la C57BL/6 J, por sus antecedentes genéticos que muestran una gran afinidad por la ingesta de etanol (kamdar y cols., 2007; Rhodes y cols., 2005), adquiridos a la empresa Charles River Laboratories España S.A. (Barcelona, España) y en este caso los animales fueron estabulados individualmente. Todos los animales fueron estabulados durante una semana para permitir su adaptación a la colonia antes de comenzar con los experimentos. La colonia estaba mantenida a $22^{\circ} \mathrm{C} \pm 1^{\circ} \mathrm{C}$, con una humedad media del 55\% e iluminación con ciclos de 12 horas de luz-oscuridad. Los experimentos se llevaron a cabo durante las horas de luz, y en todos ellos se cumplieron los procedimientos impuestos por la directiva del Consejo de la Comunidad Europea (86/609/ECC).

\subsection{DROGAS}

Todas las drogas fueron administradas de modo agudo mediante una inyección intraperitoneal (IP), utilizando como vehículo solución salina isotónica, realizada con cloruro sódico (Panreac Química S.A., España) disuelto en agua destilada a una concentración de $0.9 \% \mathrm{w} / \mathrm{v}$. Las drogas administradas fueron: 
- Etanol (Panreac Química S.A., España): Se obtuvo en disolución al 96\% v/v a partir de la cual se preparó una solución al 20\% v/v. Las dosis de etanol fueron administradas a partir de esta solución variando el volumen inyectado en función del peso del animal. El vehículo utilizado fue una solución salina isotónica.

- Clorgilina (Sigma-Aldrich Química S.A., España): Fue disuelto a concentraciones de 1.25, 2.5, 5 ó $10 \mathrm{mg}$ en $10 \mathrm{ml}$ de solución salina.

- L-Deprenil (Sigma-Aldrich Química S.A., España): Fue diluido a concentraciones de 1.25, 2.5, 5 ó $10 \mathrm{mg}$ en $10 \mathrm{ml}$ de solución salina.

- Amino-triazol (AZ) (Sigma-Aldrich Química S.A., España): Se disolvió a concentraciones de 500 ó 1000 mg en 10 ml de solución salina.

\subsection{PROCEDIMIENTOS CONDUCTUALES}

Los diversos procedimientos seguidos para la obtención de los datos fueron llevados a termino en salas de $8 \mathrm{~m}^{2}$ aisladas acusticamente con una tenue iluminación (20 W, luz blanca) para evitar el estress que producen los ambientes con iluminación intensa en los ratones. Los procedimientos seguidos son los siguientes:

\subsubsection{Actividad locomotora}

La actividad locomotora fue medida en el "campo abierto", consistente en un cilindro de cristal transparente cuyas medidas eran $25 \mathrm{~cm}$ de diámetro por $30 \mathrm{~cm}$ de altura. Toda la actividad locomotora se registró automaticamente utilizando un sistema computerizado con video cámara (SMART, Letica, S.A.). Este sistema registraba el desplazamiento del animal por el campo abierto contabilizando los centímetros totales recorridos. Los experimentos se llevaron a cabo en una sala de conducta (insonorizada) y con una luz tenue. En todos los experimentos de actividad locomotora el procedimiento fue identico, se administro las distintas dosis de pretratamiento y tras el intervalo de tiempo correspondiente a cada pretratamiento se administraron las dosis de tratamiento, introduciendo al ratón inmediatamente en el campo abierto en el cual se monitorizo su actividad 
locomotora durante 20 minutos. Para los análisis estadísticos se tomaron los últimos 15 minutos. Este intervalo de tiempo se eligió por cuatro motivos. Primero, con la intención de minimizar los efectos de activación locomotora inespecíficos producidos por la irritación peritoneal que conlleva la administración intraperitoneal de etanol en los ratones. Segundo, para reducir la activación locomotora producida por el manejo de los animales ó por la novedad del campo abierto que puede aparecer en los primeros minutos del test y que pueden enmascarar el efecto de nuestros tratamientos sobre la locomoción (Dudek y Tritto, 1994; Kelley, 1993). Trecero, para asegurar la absorción y distribución del etanol en el sistema nervioso central tras su administración intraperitoneal en el momento del test (Quetemont y cols., 2003; Yim y Gonzales, 2000). Cuarto, dado que hay un número considerable de informes en la literatura en los que se aplicaron los mismos criterios estadísticos con el mismo paradigma(Miquel y cols., 2003; Pastor y Aragon, 2006; Pastor y cols., 2002, 2005) con esta estrategia es más fácil poder comparar los resultados de estos estudios con los datos anteriores.

\subsubsection{Sensibilización}

En el paradigma de sensibilización se basa en estudios previos (Meyer y Phillips, 2003; Pastor y Aragon, 2006), y se realiza en dos fases, la fase de tratamiento y la fase del test. El protocolo seguido fue el siguiente:

- Fase de tratamiento: se les administro las dosis correspondientes durante dos semanas en días alternos, es decir se les administró el pretratamiento (dependiendo del experimento) y el tratamiento ( etanol en dosis de 0 ó $2,5 \mathrm{~g}$ ) el lunes, miercoles y viernes dos semanas seguidas, cada uno de esos días los animales fueron introducidos en el campo abierto para medir los centímetros recorridos durante 20 minutos, se les dejo descansar hasta el jueves de la tercera semana cuando se realizó la fase de test.

- Fase de test: en el test de etanol cada sujeto fue pretratado con el producto y la dosis que se le había dado cada día de la fase de sensibilización y todos los sujetos fueron tratados con una dosis de etanol de $2 \mathrm{~g} / \mathrm{kg}$ y situados en 
el campo abierto durante 20 minutos, al día siguiente se procedió como el test de etanol salvo que en esta ocasión la dosis de etanol fue de $0 \mathrm{~g} / \mathrm{kg}$.

\subsubsection{Consumo voluntario en acceso restringido}

Para estos experimentos se utilizaron ratones de la estirpe C57BL/6 J (Charles River Laboratorios España S.A., Barcelona, España) que fueron estabulados individualmente para poder medir individualmente la ingesta de líquido. El protocolo seguido es una variación del descrito por Rhodes y cols. (2005) y Kamdar y cols. (2007), conocido como "drinking in the dark" (DID) que representa un modelo animal de consumo excesivo de etanol. En dicho modelo, tras la semana de adaptación a la colonia, a los animales se les inyecto salina durante 5 días para habituarles a la presencia del investigador y de las inyecciones intraperitoneales (IP), se les dio dos días de descanso.

A la semana siguiente, se les inyecto salina durante 2 días (lunes y martes), el miercoles descansaron y durante los dos días siguientes (jueves y viernes), a la mitad de los animales se les administró el tratamiento y a la otra mitad salina, contrabalanceando los animales esos dos días (a los que se les administró tratamiento el jueves se les admistró salina el viernes y viceversa). La sustitución de los fluidos fue realizada a las 2 horas de comienzo del ciclo de oscuridad (es decir empezaban la tercera hora con el cambio de fluidos), y durante los primeros 2 días tuvieron la botella con etanol durante 2 horas para habituarles al nuevo fluido y el quinto día la tuvieron durante 4 horas para realizar el test en el cual administramos la dosis de tratamiento antes de poner las botellas de etanol (20\% v/v), teniendo dos días de descanso. La semana siguiente se procedio identicamente igual, el único cambio fue el fluido que fue agua, se dejo dos días sin administrar nada a los animales. La tercera semana se procedió como en las anteriores (semana 1 y 2 ) pero en esta ocasión el fluido elegido fue sacarina $(0,1 \%$ $\mathrm{p} / \mathrm{v})$. 


\subsection{PROCEDIMIENTOS BIOQUÍMICOS}

\subsubsection{Actividad enzimática de la catalasa cerebral}

Para medir la actividad enzimática de la catalasa cerebral se utilizaron los siguientes productos químicos:

- Potasio di-hidrógeno fosfato (Panreac Química S.A., España).

- Di-sodio fosfato (Sigma-Aldrich Química S.A., España).

- Digitonina (Sigma-Aldrich Química S.A., España).

- Heparina (Sigma-Aldrich Química S.A., España).

En cuanto a la medición de la actividad enzimática en cada muestra, se utilizó la solución Tampón fosfato. Se utilizaron dos soluciones para después unirlas en una disolución única que nos diera un pH de 7,0. Estas soluciones fueron: Potasio di-hidrógeno fosfato, 6,81 g en $1 \mathrm{l}$ de agua destilada. Di-sodio fosfato, 7,1 g en $1 \mathrm{l}$ de agua destilada. Para formar el tampón a pH 7,0 se mezclaron las dos soluciones anteriores en proporción 1 de potasio di-hidrogeno fosfato a 1,5 de di-sodio fosfato.

Con el fin de cuantificar la actividad enzimática de la catalasa se les administro a los ratones el tratamiento antes de la administración de AT $(0,0.5$ o 1 $\mathrm{g} / \mathrm{kg}$ ), dos horas despues los animales fueron perfundidos con heparina (1000 IU/I) en solución salina y se les extrajo el cerebro que fue inmediatamente congelado.

Para medir la actividad enzimática de la catalasa, el cerebro fue homogeneizado en un buffer de fosfato $(50 \mathrm{mM}, \mathrm{Ph} 7.0)$ y digitonina $(0,01 \%)$. Los homogenados de cerebro fueron centrifugados a 10000 revoluciones por minuto (rpm) durante 15 minutos en un eppendorf. Alicuotas del sobrenadante fueron utilizadas para medir los niveles de catalasa cerebral. La actividad de la catalasa cerebral fue medida espectrofotómetricamente midiendo el descenso de $\mathrm{H}_{2} \mathrm{O}_{2}$ en la absorvancia a $240 \mathrm{~nm}\left(\varepsilon_{240}=0.00394 \mathrm{mmol}^{-1} \mathrm{~mm}^{-1}\right)($ Aebi, 1974). 
En cuanto a la medición de la cantidad de proteínas, se utilizaron los siguientes productos químicos:

- Azul de coomassie G-250 (BIO-RAD Laboratorios Inc., Estados Unidos)

- Acido ortofosfórico (Panreac Química S.A., España).

- Suero de albúmina bovina (Sigma-Aldrich Química S.A., España).

- Potasio di-hidrógeno fosfato (Panreac Química S.A., España).

- Di-sodio fosfato (Sigma-Aldrich Química S.A., España).

Por lo que se refiere a la medición de la cantidad de proteínas en cada muestra, se utilizaron las siguientes soluciones:

- Bradford 5x: Azul de coomassie G-250, $100 \mathrm{mg}$ fue diluido en $50 \mathrm{ml}$ de etanol al 96\%. A esta solución se la añadieron $100 \mathrm{ml}$ de ácido ortofosfórico y agua destilada hasta completar $200 \mathrm{ml}$. Esta solución Bradford 5x fue filtrada y posteriormente diluida hasta $1 \mathrm{x}$ para su utilización en la medición de proteínas.

- Suero de albúmina bovina: Se diluyeron $15 \mathrm{mg}$ en $10 \mathrm{ml}$ de agua destilada.

- Tampón fosfato: Se utilizaron dos soluciones para después unirlas en una disolución única que nos diera un pH de 7,0. Estas soluciones fueron: Potasio di-hidrógeno fosfato, 6,81 g en $1 \mathrm{l}$ de agua destilada. Di-sodio fosfato, 7,1 g en 1 l de agua destilada. Para formar el tampón a pH 7,0 se mezclaron las dos soluciones anteriores en proporción 1 de potasio di-hidrogeno fosfato a 1,5 de di-sodio fosfato.

Para la cuantificación de la cantidad total de proteína de la muestra se utilizó un método colorimétrico (Bradford, 1976), medido con el mismo espectrofotómetro con lámpara visible a una longitud de onda de $595 \mathrm{~nm}$ en cubetas de vidrio de $3 \mathrm{ml}$ de capacidad.

\subsubsection{Niveles de etanol en sangre}

Para conocer si la clorgilina o el deprenil influian en los niveles de etanol, se utilizaron 6 ratones por grupo. Los animales fueron inyectados con el 
pretatamiento tras el cual les fue administrada una dosis de etanol 2,5 g/kg . Muestras de $20 \mathrm{ml}$ de sangre troncal fueron recogidas 10 y 20 minutos tras la administración del etanol. Cada muestra de sangre fue inmediatamente en un eppendorf que contenia $50 \mathrm{ml}$ de disolución en hielo del 5\% de sulfato de zinc ( $\mathrm{Zn}$ $\mathrm{SO}_{4}$ ) a siguiendo el procedimiento descrito en Boehm y cols. (2000). Se le añadió una alicuota de $50 \mathrm{ml}$ de 0,3 $\mathrm{mg}$ de di hidroxido de bario $\left(\mathrm{Ba}(\mathrm{OH})_{2}\right)$ y $300 \mathrm{ml}$ de agua desionizada. Tras centrifugar a 4 grados centigrados durante 5 minutos a 12.000 revoluciones por minuto (rpm), se recogió el sobrenadante y la concentración de etanol fue determinada mediante un cromatografo de gases con un detector de llama ionizada (CE instruments GC 8000, HS 850).

\subsection{FASE EXPERIMENTAL}

\subsubsection{Experimentos sobre actividad locomotora inducida por etanol}

Experimento 1: Efecto de diferentes dosis de clorgilina en la estimulación motora inducida por el etanol

Se midió la actividad locomotora de los ratones, a los cuales se les administró como pretratamiento la dosis correspondiente de clorgilina $(0,1.25,2.5,5$ ó $10 \mathrm{mg} / \mathrm{kg})$ y transcurridos 30 minutos se les inyecto etanol ( 0 ó $2.5 \mathrm{~g} / \mathrm{kg}$ ), introduciendo al animal inmediatamente en el campo abierto, donde estuvo durante 20 minutos.

Experimento 2: Efecto de la clorgilina tanto en la estimulación motora como en la depresión motora, ambas inducidas por el etanol

Se procedió de igual manera que en el experimento anterior con dosis de clorgilina de 0 ó 5 (mg/kg), con el mismo tiempo (30 minutos) y las dosis de etanol 0, 1.25, 2.5 ó $3.75(\mathrm{~g} / \mathrm{kg})$.

Experimento 3: Efecto de la clorgilina en la estimulación motora inducida por cafeína, cocaína o anfetamina

Se procedió como en el Experimento 2 (dosis de clorgilina de 0 ó $5 \mathrm{mg} / \mathrm{kg}$, con los 30 minutos entre pretratamiento y tratamiento) pero se cambiaron las dosis de tratamiento (etanol) por: 
a) cafeína (0 ó $15 \mathrm{mg} / \mathrm{kg}$ )

b) cocaína (0 ó $4 \mathrm{mg} / \mathrm{kg}$ )

c) anfetamína (0 ó $2 \mathrm{mg} / \mathrm{kg}$ )

Experimento 4: Efecto de diferentes dosis de deprenil en la estimulación motora inducida por el etanol

Se utilizaron las siguientes dosis de deprenil $(0,0.625,1.25,2.5$ ó $5 \mathrm{mg} / \mathrm{kg}$ ) y transcurridas 4 horas se les administró etanol (0 ó $2.5 \mathrm{~g} / \mathrm{kg}$ ).

Experimento 5: Efecto del deprenil en la estimulación y depresión motora inducida por etanol

Las dosis de deprenil fueron 0 ó $2.5(\mathrm{mg} / \mathrm{kg})$ y tras 4 horas las dosis de etanol que le administramos a los roedores fueron de 0,1.25, 2.5 ó 3.75 (g/kg).

Experimento 6: Efecto del deprenil en la estimulación motora inducida por cafeína, cocaína ó anfetamina

Se procedió como en el Experimento 5 pero se cambiaron las dosis de etanol por:
a) cafeína (0 ó $15 \mathrm{mg} / \mathrm{kg}$ )
b) cocaína (0 ó $4 \mathrm{mg} / \mathrm{kg}$ )
c) anfetamína (0 ó $2 \mathrm{mg} / \mathrm{kg}$ )

\subsubsection{Experimentos sobre la sensibilización motora inducido por etanol}

Experimento 7: Efecto de la clorgilina en un paradigma de sensibilización

Se utilizó el protocolo de sensibilización en el cual en la fase de tratamiento se utilizaron como pretratamiento dosis de clorgilina de 0 ó $5 \mathrm{mg} / \mathrm{kg}$ y transcurridos 30 minutos se les admistró el tratamiento (etanol en dosis de 0 ó 2,5g/kg). En la fase de test únicamente se les administro una sustancia, el primer día de test etanol å2,0 g/kg) y el segundo día se les administró una solución salina.

Experimento 8: Efecto del deprenil en un paradigma de sensibilización

Se procedió como en el Experimento 7 pero en esta ocasión en la fase de tratamiento se utilizó el deprenil como pretatamiento con dosis de 0 ó 2,5 mg/kg y 
tras 4 horas se les administró el tratamiento con etanol a dosis de 0 ó 2,5 g/ $\mathrm{kg}$. La fase de test fue exactamente igual que en el experimento anterior.

\subsubsection{Experimentos sobre el consumo voluntario de etanol}

\section{Experimento 9: Efecto de la clorgilina sobre la ingesta voluntaria de etanol}

Se procedió con el protocolo explicado en el apartado 3.3.3 de los materiales y métodos, durante los primeros 2 dias a los animales se les admistró una solución salina 30 minutos antes de cambiar la botella de agua por la de etanol y tras un día de descanso se procedió a administrar a los animales salina ó clorgilina (5mg/kg) 30 minutos antes del cambio de botellas, contrabalanceando esos dos días los animales que recibian salina ó clorgilina, se midió la cantidad de etanol consumida por cada animal a las dos horas y a las cuatro horas de tener el etanol a su disposición.

Experimento 10: Efecto de la clorgilina sobre la ingesta voluntaria de agua

Se siguio exactamente el mismo procedimiento que en el experimento anterior, cambiando tan sólo el fluido de la botella (que en este caso fue agua) y se tomaron medidas a las $2 \mathrm{y}$ a las 4 horas.

Experimento 11: Efecto de la clorgilina sobre la ingesta voluntaria de sacarina $(0,1 \%)$

El fluido utilizado en este experimento fue una solución de sacarina en agua al $0,1 \%$.

Experimento 12: Efecto del deprenil en la ingesta voluntaria de etanol

En este caso la manipulación (administración IP de salina o de l-deprenil 2,5 $\mathrm{mg} / \mathrm{kg}$ ) de los animales tanto la semana anterior como las semanas de test fue 4 horas antes del cambio de fluidos, en este caso durante el ciclo de luz, realizandose el cambio de fluidos (etanol 20\%) dos horas después del cambio de ciclo (oscuridad), midiendo cada 2 y 4 horas. También hubo contrabalanceo de los animales el jueves y viernes. 
Experimento 13: Efecto del deprenil sobre la ingesta voluntaria de agua

Se siguió el mismo procedimiento que en el Experimento 12 pero el fluido utilizado fue agua.

Experimento 14: Efecto del deprenil sobre la ingesta voluntaria de sacarina

En este experimento el fluido utilizado fue la sacarina diluida al 0,1\%.

\subsubsection{Experimentos sobre la actividad enzimática de la catalasa}

Experimento 15: Actividad enzimática de la catalasa tras la administración de clorgilina y deprenil

Se administró a los animales el tratamiento 30 minutos antes en el caso de clorgilina $5 \mathrm{mg} / \mathrm{kg}$ y 4 horas antes para el l-deprenil 2,5 mg/kg, en ambos casos había un grupo control al que se le administró salina (30 minutos ó 4 horas antes) que la administración de AT (0, 0.5 ó $1 \mathrm{~g} / \mathrm{kg})$ y a las dos horas se les extrajo el cerebro, realizando el procedimiento bioquímico descrito para obtener la actividad encimática de la catalasa.

\subsubsection{Experimentos sobre los niveles de etanol en sangre}

Experimento 16: Niveles de etanol en sangre

A los animales se les administró clorgilina (0 ó $5 \mathrm{mg} / \mathrm{kg}$ ) y 30 minutos después se les inyectó etanol 2,5 g/ $\mathrm{kg}$, ó deprenil (0 ó 2,5 mg/kg) y 4 horas después etanol $2,5 \mathrm{~g} / \mathrm{kg}$, en ambos casos se tomarón muestras de sangre troncal a los 10 y los 20 minutos de la administración del etanol. 


\section{RESULTADOS}

\subsection{EXPERIMENTOS SOBRE ACTIVIDAD LOCOMOTORA INDUCIDA POR ETANOL}

Experimento 1: Efecto de diferentes dosis de clorgilina en la estimulación motora inducida por el etanol

La Figura 1 muestra el efecto sobre la actividad locomotora inducida por etanol $(2,5 \mathrm{~g} / \mathrm{kg})$ de diferentes dosis de clorgilina $(0,1.25,2.5,5$ o $10 \mathrm{mg} / \mathrm{kg})$, un inhibidor de la MAO-A. Un ANOVA de dos factores [Tratamiento de clorgilina $\mathrm{x}$ dosis de etanol] reveló una diferencia significativa para las dosis de clorgilina $[F(4,94)=4.88, p<0.01]$, un efecto significativo del etanol $[F(1,94)=4.54, p<0.05]$ y un efecto sobre la interacción entre la clorgilina y el etanol $[F(4,94)=3.17$, $\mathrm{p}<0.05]$. Un test de Newman-Keuls mostró que el grupo clorgilina $(0 \mathrm{mg} / \mathrm{kg})$ y etanol $(2.5 \mathrm{~g} / \mathrm{kg})$ tenían un incremento significativo de la actividad locomotora ( $\mathrm{p}<0.05$ ) comparado con el grupo control (clorgilina $0 \mathrm{mg} / \mathrm{kg}$ y etanol $0 \mathrm{~g} / \mathrm{kg}$ ), los grupos clorgilina ( 5 and $10 \mathrm{mg} / \mathrm{kg}$ ) y etanol $(2.5 \mathrm{~g} / \mathrm{kg}$ ) mostraron un bloqueo en el aumento de la locomoción comparado con el grupo clorgilina $0 \mathrm{mg} / \mathrm{kg}$ y etanol 2.5 $\mathrm{g} / \mathrm{kg}(\mathrm{p}<0.01$, en ambos grupos). No hubo diferencias entre el grupo control y los grupos de clorgilina $(1.25,2.5,5$ o $10 \mathrm{mg} / \mathrm{kg}$ ) y etanol $0 \mathrm{~g} / \mathrm{kg}$. La dosis de clorgilina de $5 \mathrm{mg} / \mathrm{kg}$ bloqueó el efecto del etanol sobre la locomoción, mientras que la dosis de $10 \mathrm{mg} / \mathrm{kg}$ de clorgilina no sólo bloqueó el aumento de la actividad locomotora provocado por el etanol 2,5 g/kg sino que produjo un ligero descenso en la actividad locomotora.

Esto nos indica que la clorgilina en la dosis de $5 \mathrm{mg} / \mathrm{kg}$ administrada 30 minutos antes de la administración de etanol 2,5 g/kg bloquea el efecto del etanol sobre la actividad locomotora. 


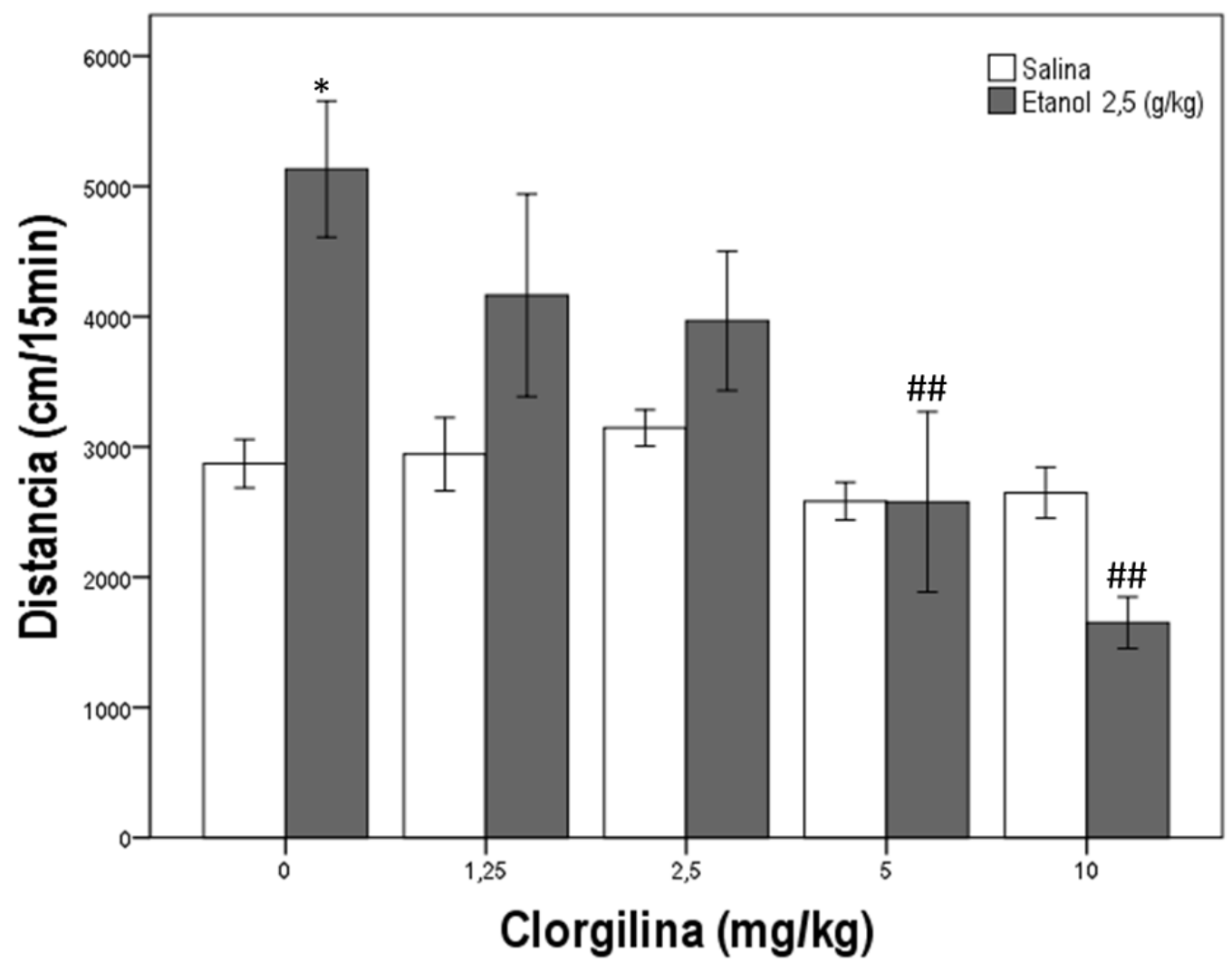

Figura 1: Efecto de diferentes dosis de clorgilina $(0,1.25,2.50,5$ o $10 \mathrm{mg} / \mathrm{kg}$ ) sobre la estimulación motora producida por etanol $(0$ o $2.5 \mathrm{~g} / \mathrm{kg}$ ). * $p<0.05$ respecto al grupo clorgilina $0 \mathrm{mg} / \mathrm{kg}$ y etanol $0 \mathrm{~g} / \mathrm{kg}$. \#\# $p<0.01$ respecto al grupo clorgilina $0 \mathrm{mg} / \mathrm{kg}$ y etanol $2.5 \mathrm{~g} / \mathrm{kg}$.

Experimento 2: Efecto de la clorgilina (0 o $5 \mathrm{mg} / \mathrm{kg}$ ) tanto en la estimulación motora como en la depresión motora, ambas inducidas por el etanol

Como se puede ver en la Figura 2, hay un efecto de las dosis de clorgilina (0 o 5 $\mathrm{mg} / \mathrm{kg}$ ) en distintas dosis de etanol $(0,1.25,2.5$ y $3.75 \mathrm{~g} / \mathrm{kg})$. Un ANOVA de dos factores [Tratamiento de clorgilina $\mathrm{x}$ dosis de etanol] mostró diferencias significativas tanto para la clorgilina $(\mathrm{F}(1,68)=13.27, \mathrm{p}<0.01)$, el etanol $(F(3,68)=26.68, p<0.01)$ y la interacción entre los dos $(F(3,68)=4.28, p<0.01)$. Un test de Newman-Keuls reveló un aumento significativo en la actividad locomotora en el grupo tratado con clorgilina $0 \mathrm{mg} / \mathrm{kg}$ y etanol $2.5 \mathrm{~g} / \mathrm{kg}(\mathrm{p}<0.01)$ al compararlo con el grupo tratado con clorgilina $0 \mathrm{mg} / \mathrm{kg}$ y etanol $0 \mathrm{~g} / \mathrm{kg}$, y en comparación del grupo clorgilina $5 \mathrm{mg} / \mathrm{kg}$ y etanol $2.5 \mathrm{~g} / \mathrm{kg}(\mathrm{p}<0.01)$. Los grupos tratados con clorgilina ( 0 o $5 \mathrm{mg} / \mathrm{kg}$ ) y etanol $3.75 \mathrm{~g} / \mathrm{kg}$ presentaron un descenso significativo en la actividad locomotora $(p<0.01)$ en comparación con el grupo clorgilina $0 \mathrm{mg} / \mathrm{kg}$ y etanol $0 \mathrm{~g} / \mathrm{kg}$ ). Por lo que podemos decir que la dosis de 
clorgilina de $5 \mathrm{mg} / \mathrm{kg}$ bloquea los efectos estimulantes que el etanol tiene sobre la actividad locomotora en ratones.

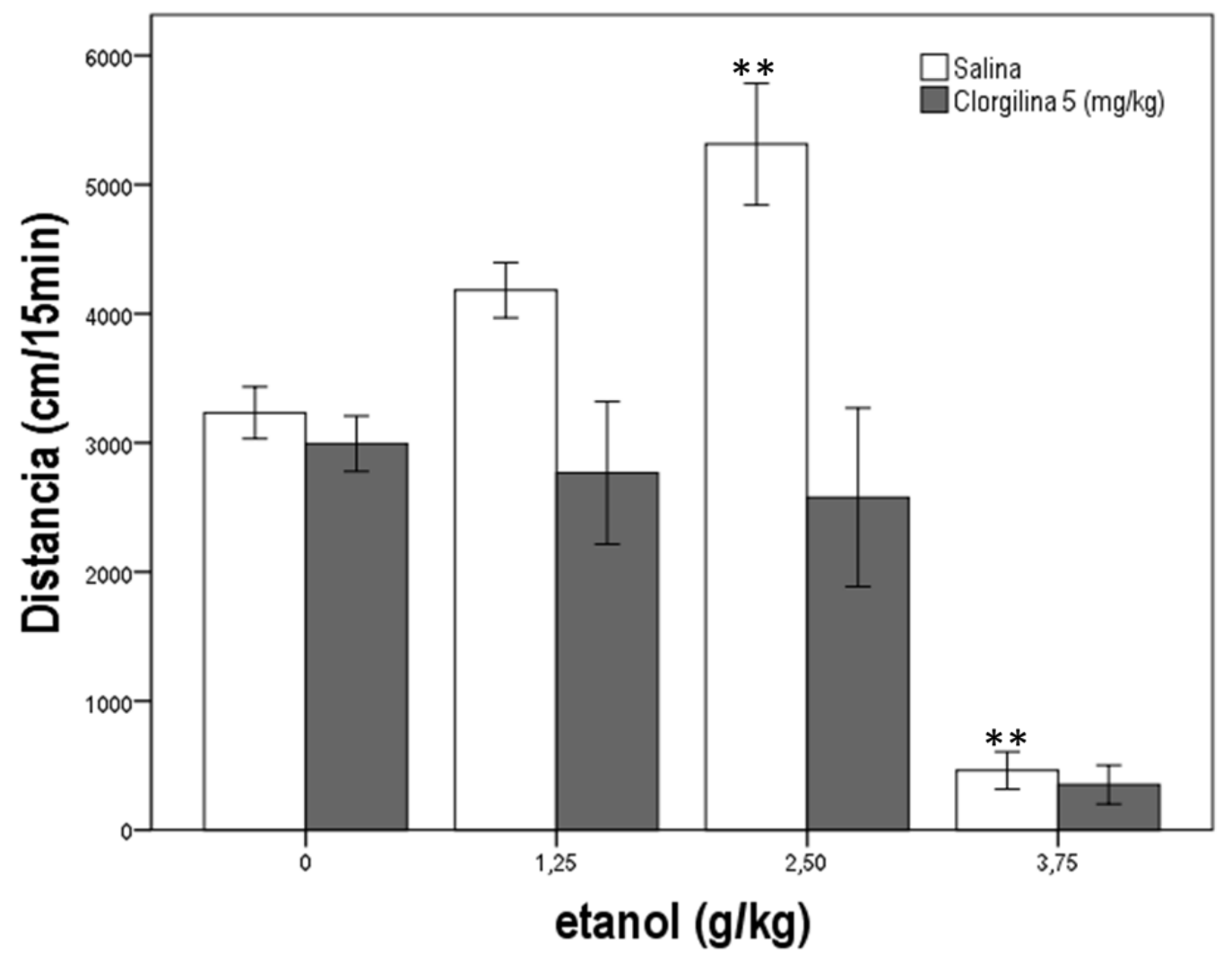

Figura 2: Efecto de la clorgilina (0 o $5 \mathrm{mg} / \mathrm{kg}$ ) sobre la estimulación/depresión motora producida por diferentes dosis de etanol $(0,1.25,2.5$ o $3.75 \mathrm{~g} / \mathrm{kg}) .{ }^{* *} p<0.01$ respecto al grupo clorgilina $0 \mathrm{mg} / \mathrm{kg}$ y etanol $0 \mathrm{~g} / \mathrm{kg}$.

Experimento 3: Efecto de la clorgilina (0 o $5 \mathrm{mg} / \mathrm{kg})$ en la estimulación motora inducida por cafeína (0 o $15 \mathrm{mg} / \mathrm{kg}$ ), cocaína (0 o $4 \mathrm{mg} / \mathrm{kg}$ ) o anfetamina (0 o $2 \mathrm{mg} / \mathrm{kg}$ )

La Figura 3 (a, b y c) representa el efecto de la clorgilina ( 0 o 5 r mg/kg) sobre diferentes drogas estimuladoras de la actividad locomotora:

a) Cafeína (0 o $15 \mathrm{mg} / \mathrm{kg}$ ), Un ANOVA de dos factores [Tratamiento de clorgilina $\mathrm{x}$ dosis de cafeína] mostró diferencias significativas únicamente para la cafeína $(F(1,32)=11.50, p<0.01)$, pero no para la clorgilina ni la interaccion entre ambas. Un test de Newman-Keuls reveló un aumento significativo en la actividad locomotora en los animales que recibieron cafeína $(15 \mathrm{mg} / \mathrm{kg})$ frente a los que no habían recibido cafeína, sin diferenciar si habían recibido clorgilina o no. Por lo tanto, la clorgilina no 
produjo ningún efecto sobre la estimulación motora inducida por la cafeína.

b) Cocaína ( $\left.\begin{array}{llll}0 & \text { o } & 4 \mathrm{mg} / \mathrm{kg}\end{array}\right)$, Un ANOVA de dos factores [Tratamiento de clorgilina $\mathrm{x}$ dosis de cocaína] mostró diferencias significativas sólo para la cocaína $(F(1,31)=57.23, p<0.01)$, pero no para la clorgilina ni la interaccion entre ambas. Un test de Newman-Keuls reveló un aumento significativo en la actividad locomotora en los animales que recibieron cocaína (4 mg/kg) frente a los que no habían recibido cocaína, sin diferenciar si habían recibido clorgilina o no. Es decir, la clorgilina tampoco causa efecto sobre el incremento en la locomoción que provoca la cocaína.

c) Anfetamina (0 o $2 \mathrm{mg} / \mathrm{kg}$ ), Un ANOVA de dos factores [Tratamiento de clorgilina $\mathrm{x}$ dosis de anfetamina] mostró diferencias significativas tan solo para la anfetamina $(F(1,30)=16.90, p<0.01)$, pero no para la clorgilina ni la interaccion entre ambas. Un test de Newman-Keuls reveló un aumento significativo en la actividad locomotora en los animales que recibieron anfetamina (2 $\mathrm{mg} / \mathrm{kg}$ ) frente a los que no habían recibido anfetamina, sin diferenciar si habían recibido clorgilina o no. Por lo tanto, la clorgilina no tiene ningún efecto sobre el aumento de la distancia recorrida por los ratones ante una dosis de anfetamina.

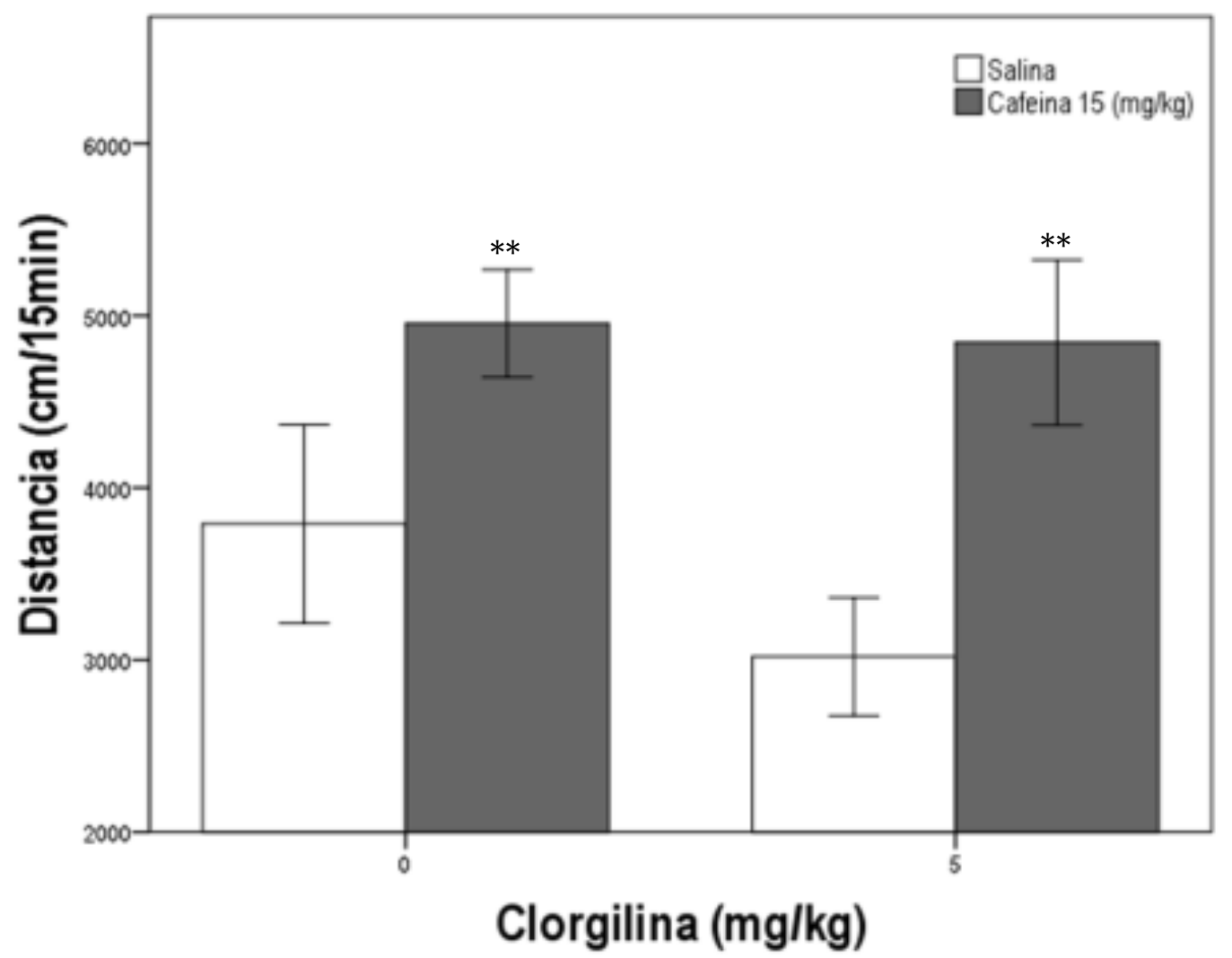

Figura 3: a) Efecto de la clorgilina (0 o $5 \mathrm{mg} / \mathrm{kg}$ ) sobre la estimulación motora producida por cafeína (0 ó $15 \mathrm{mg} / \mathrm{kg}$ ). ${ }^{* *} p<0.01$, respecto a su mismo grupo con salina. 


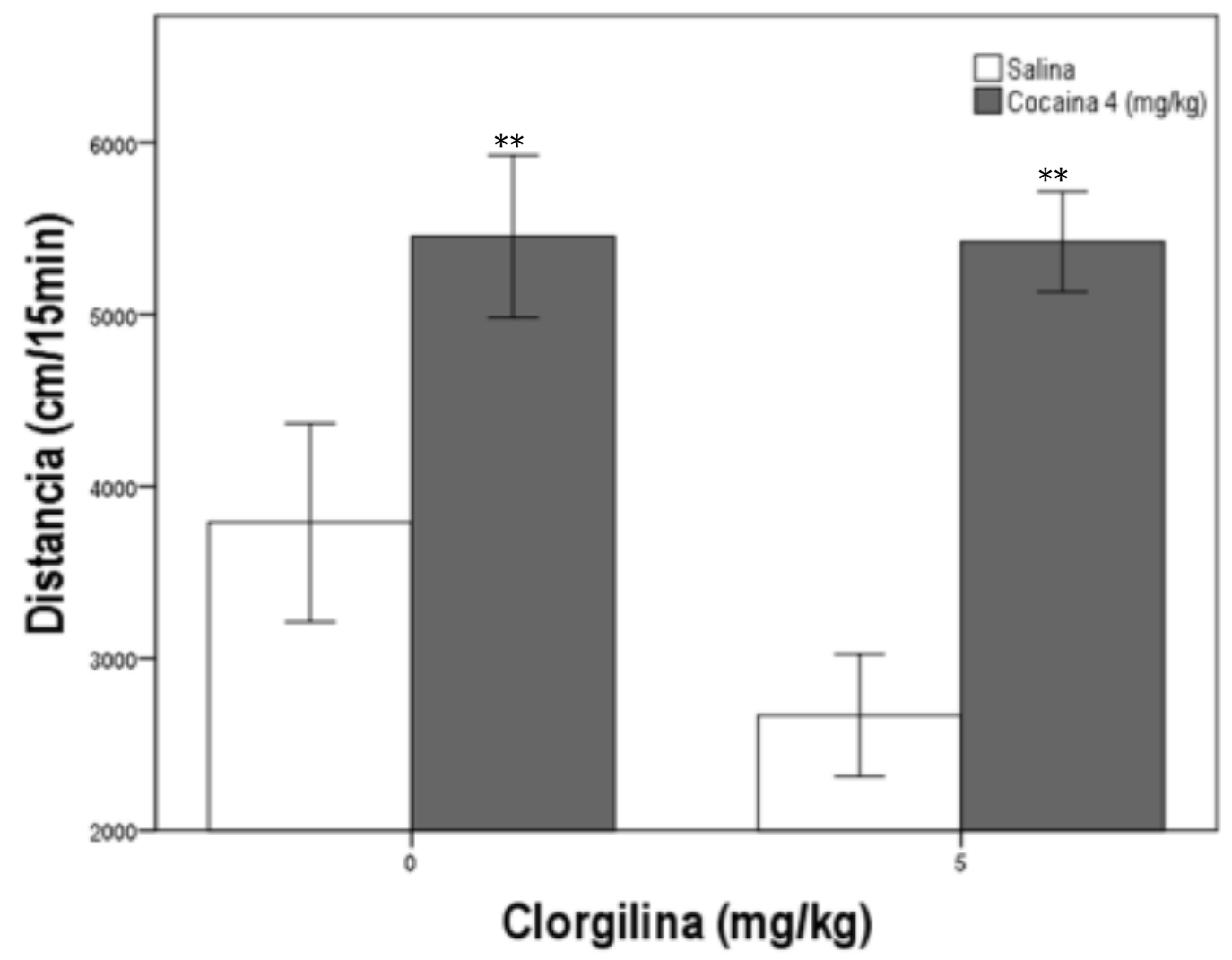

Figura 3: b) Efecto de la clorgilina (0 o $5 \mathrm{mg} / \mathrm{kg}$ ) sobre la estimulación motora producida por cocaína (0 ó $4 \mathrm{mg} / \mathrm{kg}$ ). ${ }^{* *} p<0.01$, respecto a los grupos salina.

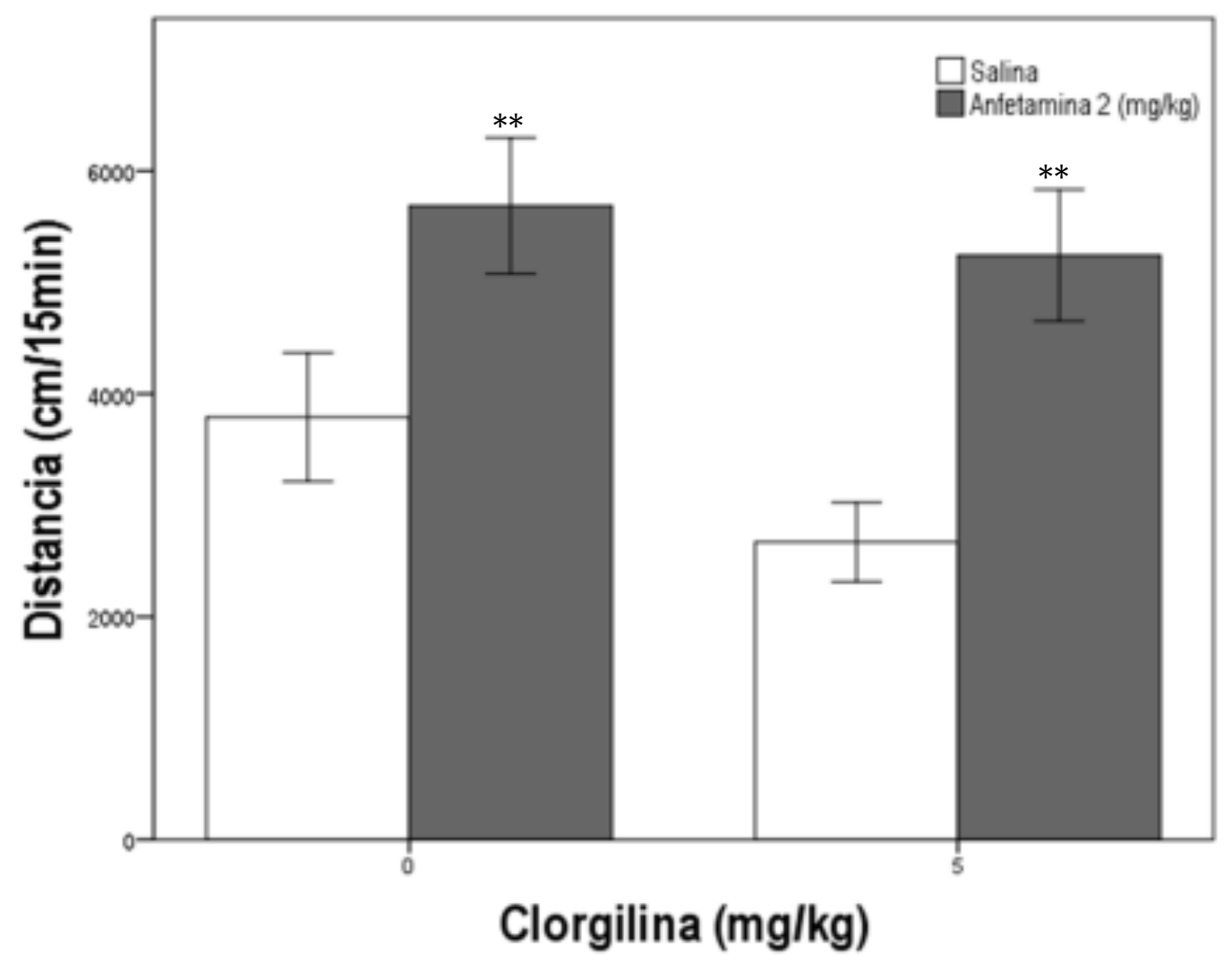

Figura 3: c) Efecto de la clorgilina (0 o $5 \mathrm{mg} / \mathrm{kg}$ ) sobre la estimulación motora producida por anfetamina (0 ó $2 \mathrm{mg} / \mathrm{kg}$ ). ). ** $p<0.01$, respecto a los grupos salina. 
Como se puede observar en las Figuras 3a, 3b y 3c, la clorgilina no tiene ningún efecto sobre el incremento de la actividad locomotora que provocan la cafeína $15 \mathrm{mg} / \mathrm{kg}$, la cocaína $4 \mathrm{mg} / \mathrm{kg}$ ni la anfetamina $2 \mathrm{mg} / \mathrm{kg}$.

Experimento 4: Efecto de diferentes dosis de deprenil en la estimulación motora inducida por el etanol

En la Figura 4 vemos el efecto del deprenil (0, 0.625, 1.25, 2.5 o $5 \mathrm{mg} / \mathrm{kg}$ ), administrado (IP) 4 horas antes que la inyección de etanol (0 o $2.5 \mathrm{~g} / \mathrm{kg}$ ), sobre la estimulación locomotora inducida por el etanol. Un ANOVA de dos factores [Tratamiento de deprenil $(0,0.625,1.25,2.5$ o $5 \mathrm{mg} / \mathrm{kg}$ ) x dosis de etanol (0 o 2.5 $\mathrm{g} / \mathrm{kg})]$ reveló un efecto significativo del deprenil $[\mathrm{F}(4,82)=2.76, \mathrm{p}<0.05]$, un efecto significativo del etanol $[\mathrm{F}(1,82)=14.30, \mathrm{p}<0.01]$ y un efecto significativo sobre la interacción entre el deprenil y el etanol $[\mathrm{F}(4,82)=2.54, \mathrm{p}<0.05]$. Un test de Newman-Keuls muestra que el grupo deprenil $(0 \mathrm{mg} / \mathrm{kg})$ y etanol $(2.5 \mathrm{~g} / \mathrm{kg})$ tuvo un aumento significativo de la locomoción $(\mathrm{p}<0.01)$ al compararlo con el grupo control (deprenil $0 \mathrm{mg} / \mathrm{kg}$ y etanol $0 \mathrm{~g} / \mathrm{kg}$ ), los grupos deprenil (2.5 and $5 \mathrm{mg} / \mathrm{kg}$ ) y etanol $(2.5 \mathrm{~g} / \mathrm{kg})$ muestran un bloqueo del aumento en la actividad locomotora al compararlos con el grupo deprenil $0 \mathrm{mg} / \mathrm{kg}$ y etanol $2.5 \mathrm{~g} / \mathrm{kg}(\mathrm{p}<0.05 \mathrm{y} \mathrm{p}<0.01$, respectivamente). No hubo diferencias entre el grupo control (deprenil $0 \mathrm{mg} / \mathrm{kg}$ y etanol $0 \mathrm{~g} / \mathrm{kg}$ ) con los grupos de deprenil $(0.625,1.25,2.5$ y $5 \mathrm{mg} / \mathrm{kg}$ ) y etanol 0 $\mathrm{g} / \mathrm{kg}$. Lo que nos indica que las dosis de deprenil de $2,5 \mathrm{mg} / \mathrm{kg}$ y la de $5 \mathrm{mg} / \mathrm{kg}$ administradas 4 horas antes que la administración de etanol 2,5 g/kg bloquean el efecto que este último tiene sobre la actividad locomotora. 


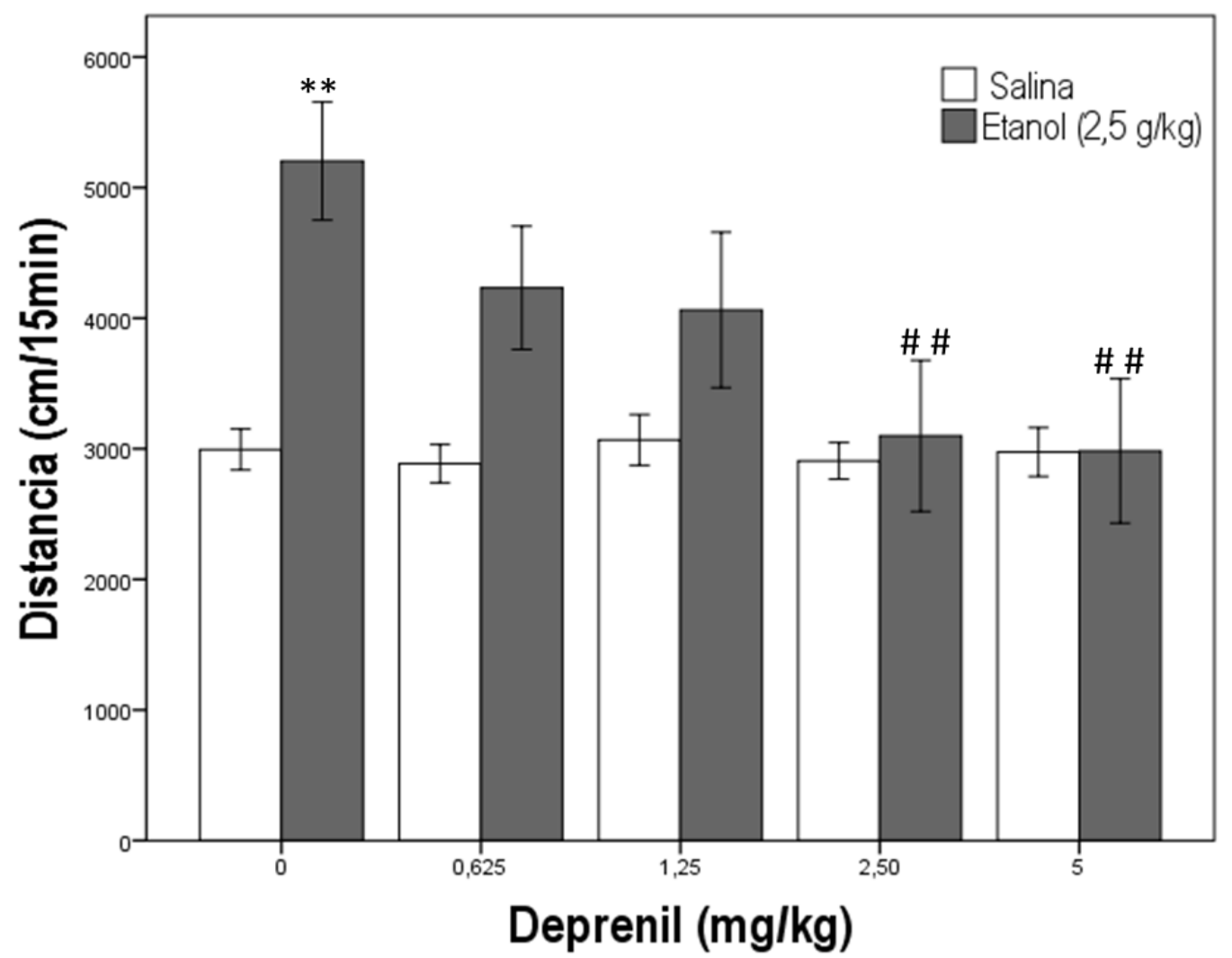

Figura 4: Efecto de diferentes dosis de deprenil $(0,0.625,1.25,2.50$ o $5 \mathrm{mg} / \mathrm{kg}$ ) sobre la estimulación motora producida por etanol $\left(0 \circ 2.5 \mathrm{~g} / \mathrm{kg}\right.$ ). ${ }^{* *} p<0.01$ respecto al grupo deprenil $0 \mathrm{mg} / \mathrm{kg}$ y etanol $0 \mathrm{~g} / \mathrm{kg}$. \#\# $p<0.01$ respecto al grupo deprenil $0 \mathrm{mg} / \mathrm{kg}$ y etanol $2.5 \mathrm{~g} / \mathrm{kg}$.

Experimento 5: Efecto del deprenil ( 0 o $2.5 \mathrm{mg} / \mathrm{kg}$ ) en la estimulación y depresión motora inducida por etanol

La Figura 5 presenta el efecto del deprenil ( 0 o $2.5 \mathrm{mg} / \mathrm{kg}$ ) sobre diferentes dosis de etanol (0, 1.25, 2.5 o $3.75 \mathrm{~g} / \mathrm{kg})$. Un ANOVA de dos factores [dosis de deprenil (0 o $2.5 \mathrm{mg} / \mathrm{kg})$ x etanol $(0,1.25,2.5$ o $3.75 \mathrm{~g} / \mathrm{kg})]$ reveló un efecto significativo del deprenil $(\mathrm{F}(1,62)=4.90, \mathrm{p}<0.05)$, etanol $(\mathrm{F}(3,62)=11.95, \mathrm{p}<0.01)$, así como de la interacción entre ambos $(F(3,67)=3.98, p<0.05)$. Un test de Newman-Keuls mostró un incremento significativo de la actividad locomotora para el grupo tratado con deprenil $0 \mathrm{mg} / \mathrm{kg}$ y etanol $2.5 \mathrm{~g} / \mathrm{kg}(\mathrm{p}<0.01)$ comparado con el grupo tratado con deprenil $0 \mathrm{mg} / \mathrm{kg}$ y etanol $0 \mathrm{~g} / \mathrm{kg}$, y comparado con el grupo deprenil $2.5 \mathrm{mg} / \mathrm{kg}$ and etanol $2.5 \mathrm{~g} / \mathrm{kg}$ ( $\mathrm{p}<0.01$, en ambos casos). El grupo tratado con deprenil $(0 \mathrm{mg} / \mathrm{kg})$ y etanol $3.75 \mathrm{~g} / \mathrm{kg}$ presentan una disminución significativa en la actividad locomotora $(\mathrm{p}<0.01)$ comparado con el grupo deprenil $0 \mathrm{mg} / \mathrm{kg}$ and etanol $2.5 \mathrm{~g} / \mathrm{kg}$ ). Lo cual nos indica que el deprenil (2,5 mg/kg) administrado 4 
horas antes que el etanol (2,5 g/ $\mathrm{kg})$ bloquea la activación de la actividad locomotora pero no el efecto depresor de dosis más altas de etanol (3,75 g/kg).

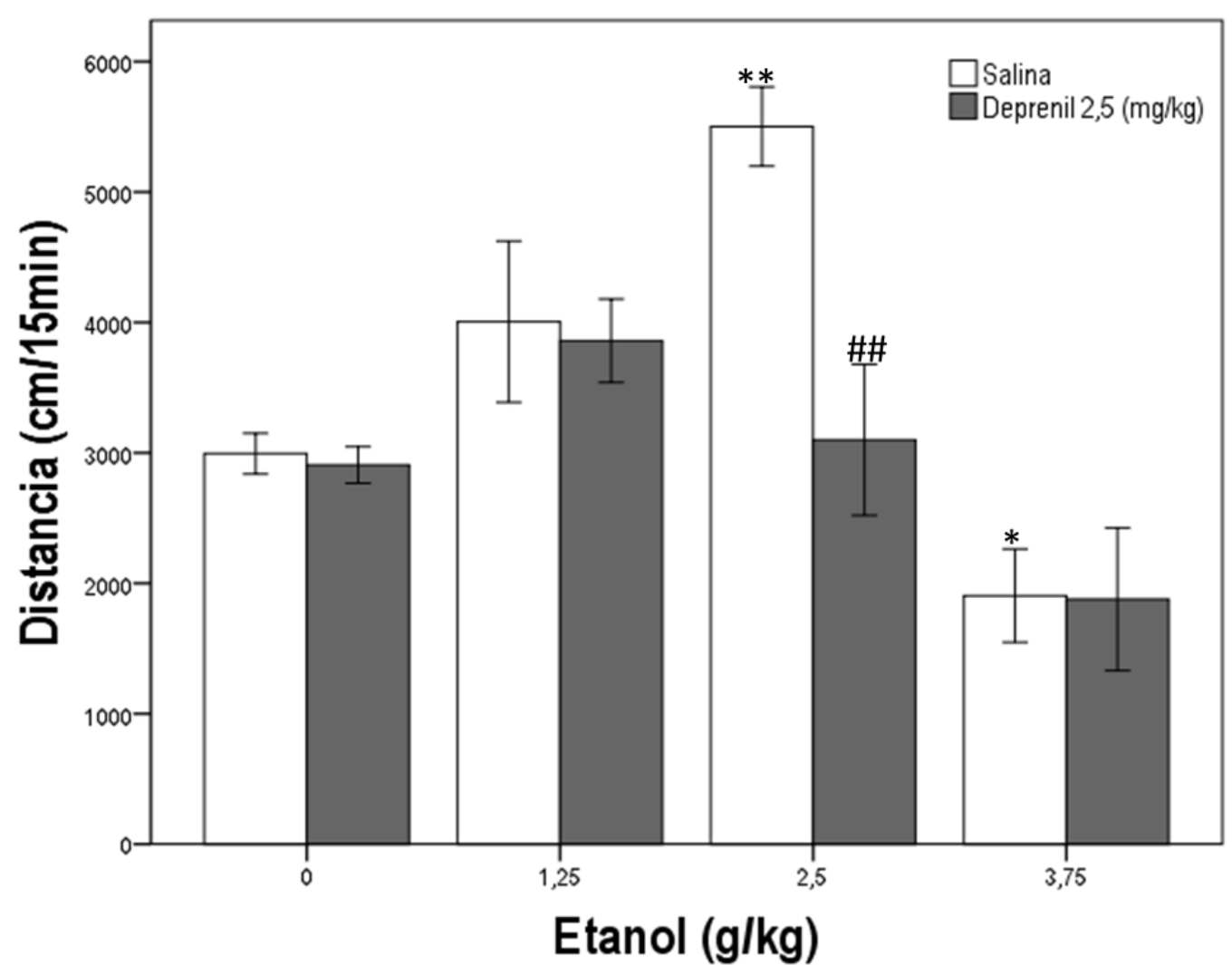

Figura 5: Efecto del deprenil ( 0 o $2.5 \mathrm{mg} / \mathrm{kg}$ ) sobre la estimulación/depresión motora producida por diferentes dosis de etanol $(0,1.25,2.5$ o $3.75 \mathrm{~g} / \mathrm{kg}) .{ }^{* *} p<0.01,{ }^{*} p<0.05$ respecto al grupo deprenil $0 \mathrm{mg} / \mathrm{kg}$ y etanol $0 \mathrm{~g} / \mathrm{kg}$. \#\# $p<0.01$ respecto al grupo deprenil $0 \mathrm{mg} / \mathrm{kg} \mathrm{y}$ etanol $2.5 \mathrm{~g} / \mathrm{kg}$.

Experimento 6: Efecto del deprenil ( 0 o $2.5 \mathrm{mg} / \mathrm{kg}$ ) en la estimulación motora inducida por cafeína (0 o $15 \mathrm{mg} / \mathrm{kg}$ ), cocaína (0 o $4 \mathrm{mg} / \mathrm{kg}$ ) o anfetamina (0 o $2 \mathrm{mg} / \mathrm{kg}$ )

La Figura 6 (a, b y c) representa el efecto del deprenil ( 0 o $2.5 \mathrm{mg} / \mathrm{kg}$ ) sobre diferentes drogas estimuladoras de la actividad locomotora:

a) Cafeína (0 o $15 \mathrm{mg} / \mathrm{kg}$ ), Un ANOVA de dos factores [Tratamiento de deprenil $\mathrm{x}$ dosis de cafeína] mostró diferencias significativas únicamente para la cafeína $(F(1,32)=75.21, p<0.01)$, pero no para el deprenil ni la interaccion entre ambas. Un test de Newman-Keuls reveló un aumento significativo en la actividad locomotora en los animales que recibieron cafeína $(15 \mathrm{mg} / \mathrm{kg})$ frente a los que no habían recibido cafeína, sin 
diferenciar si habían recibido deprenil o no. El deprenil no produce ningún efecto sobre la estimulación motora inducida por la cafeína.

b) Cocaína (0 o $4 \mathrm{mg} / \mathrm{kg}$ ), Un ANOVA de dos factores [Tratamiento de deprenil $\mathrm{x}$ dosis de cocaína] mostró diferencias significativas únicamente para la cocaína $(\mathrm{F}(1,28)=122.24$, $\mathrm{p}<0.01)$, pero no para el deprenil ni la interaccion entre ambas. Un test de Newman-Keuls reveló un aumento significativo en la actividad locomotora en los animales que recibieron cocaína (4 mg/kg) frente a los que no habían recibido cocaína, sin diferenciar si habían recibido deprenil o no. Es decir, el deprenil tampoco causa efecto sobre el incremento en la locomoción que provoca la cocaína.

c) Anfetamina (0 o $2 \mathrm{mg} / \mathrm{kg}$ ), Un ANOVA de dos factores [Tratamiento de clorgilina $\mathrm{x}$ dosis de cafeína] mostró diferencias significativas únicamente para la anfetamina $(F(1,32)=39.37, \mathrm{p}<0.01)$, pero no para el deprenil ni la interaccion entre ambas. Un test de Newman-Keuls reveló un aumento significativo en la actividad locomotora en los animales que recibieron anfetamina $(2 \mathrm{mg} / \mathrm{kg}$ ) frente a los que no habían recibido anfetamina, sin diferenciar si habían recibido deprenil o no. El deprenil no tiene ningún efecto sobre el aumento de la distancia recorrida por los ratones ante una dosis de anfetamina.

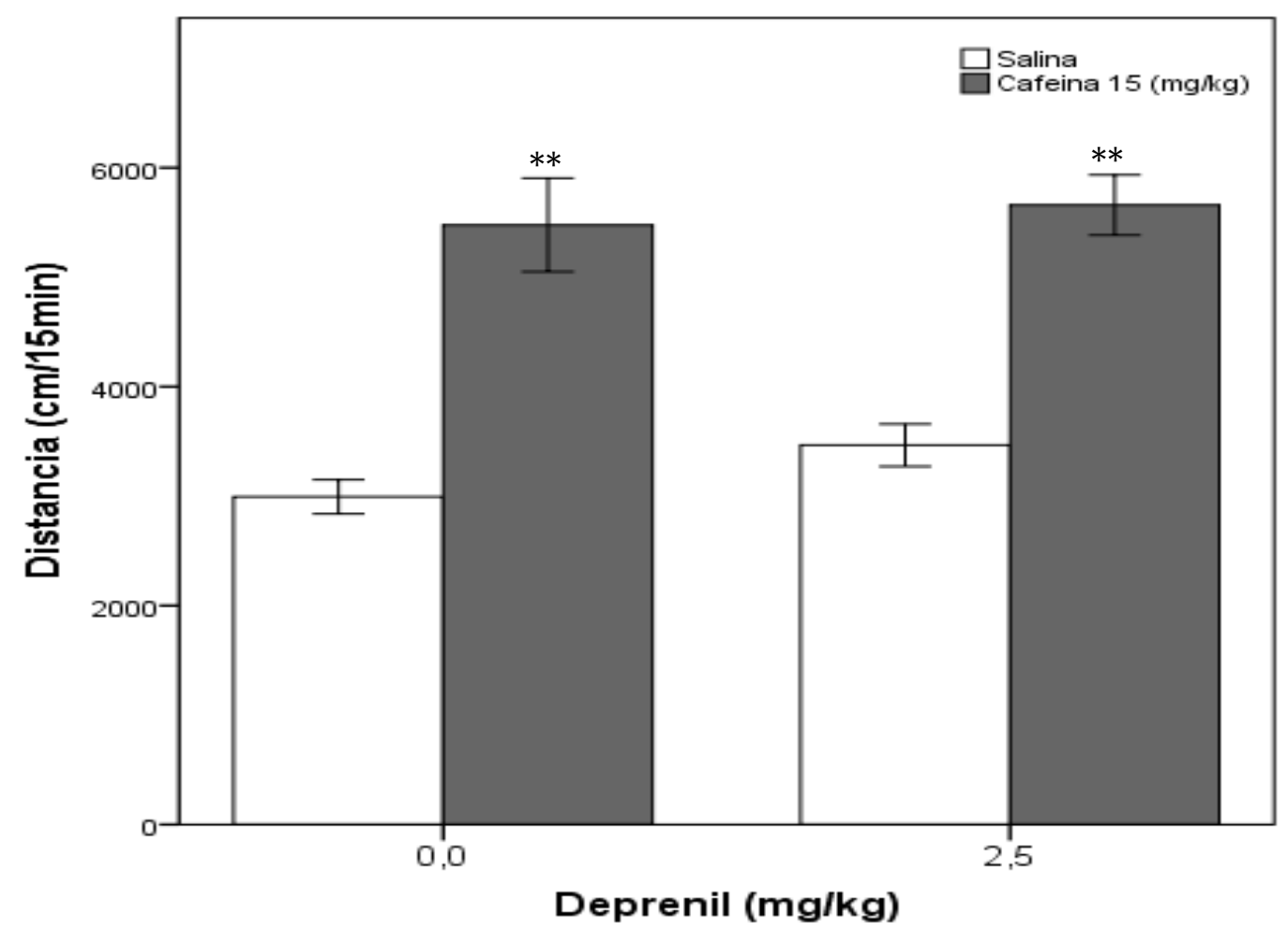

Figura 6: a) Efecto del deprenil ( 0 o $2.5 \mathrm{mg} / \mathrm{kg}$ ) sobre la estimulación motora producida por cafeína (0 ó $15 \mathrm{mg} / \mathrm{kg}$ ). ). ${ }^{* *} p<0.01$, respecto a los grupos salina. 




Figura 6: b) Efecto del deprenil (0 o $2.5 \mathrm{mg} / \mathrm{kg}$ ) sobre la estimulación motora producida por cocaína (0 ó $4 \mathrm{mg} / \mathrm{kg}$ ). ). ${ }^{* *} p<0.01$, respecto a los grupos salina.

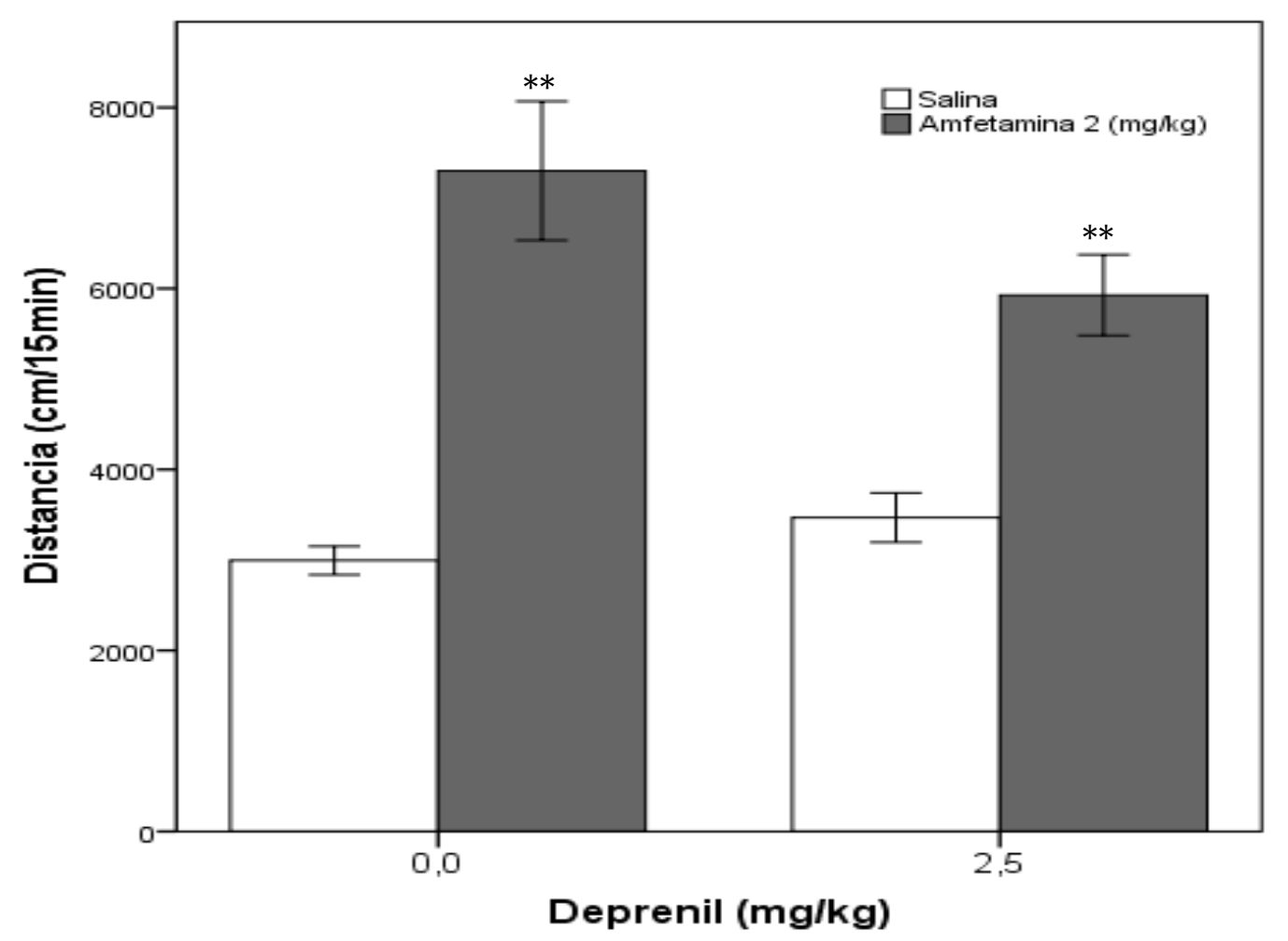

Figura 6: c) Efecto del deprenil (0 o $2.5 \mathrm{mg} / \mathrm{kg}$ ) sobre la estimulación motora producida por anfetamina (0 ó $2 \mathrm{mg} / \mathrm{kg}$ ). ). ** $p<0.01$, respecto a los grupos salina. 


\subsection{EXPERIMENTOS SOBRE LA SENSIBILIZACIÓN MOTORA INDUCIDA POR ETANOL}

Experimento 7: Efecto de la administración de clorgilina (0 o $5 \mathrm{mg} / \mathrm{kg}$ ) en la sensibilización motora inducida por el etanol

Como se ve en la Figura 7, la clorgilina ( 0 o $5 \mathrm{mg} / \mathrm{kg}$ ) no produce ningún efecto sobre la sensibilización motora inducida por el etanol. En la fase de tratamiento únicamente resultó significativo el factor etanol $[F(2,94)=159,03, p<0.01]$ pero no el tratamiento con clorgilina ni la interacción de ambos. Se puede decir que los animales a los que se les administró etanol tienen sensibilización motora inducida por etanol, como demuestra que el día del test de etanol ambos grupos tienen diferencias significativas con los grupos que no habían recibido etanol durante la fase de tratamiento $(\mathrm{p}<0,05)$.

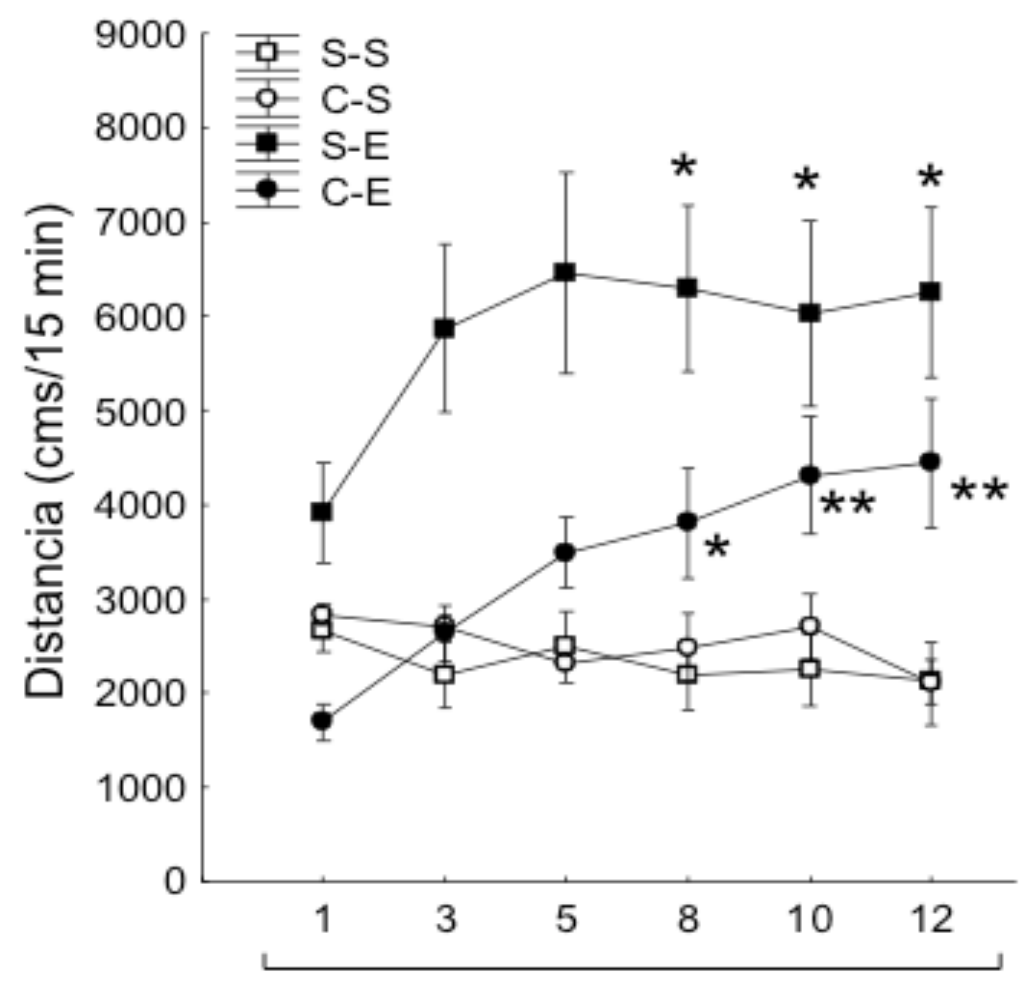

Fase de tratamiento

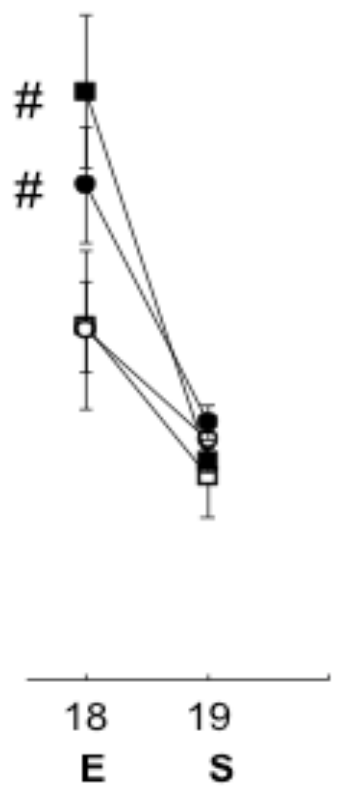

tests

Figura 7: Efecto de la clorgilina (5 $\mathrm{mg} / \mathrm{kg}$ ) o salina sobre la sensibilización motora producida por etanol (0 o $2.5 \mathrm{~g} / \mathrm{kg}$ ).C-E clorgilina $5 \mathrm{mg} / \mathrm{kg}$ - etanol 2,5 g/ $\mathrm{kg}$. $S$-E clorgilina $0 \mathrm{mg} / \mathrm{kg}$ etanol 2,5 g/kg. C-S clorgilina $5 \mathrm{mg} / \mathrm{kg}$ - etanol $0 \mathrm{~g} / \mathrm{kg}$. $S$-S clorgilina $0 \mathrm{mg} / \mathrm{kg}$ - etanol $0 \mathrm{~g} / \mathrm{kg}$. * $p<0.05$ respecto al primer día de su grupo.** $p<0.01$ respecto al primer día de su grupo. \# $p<0.05$ respecto a los grupos que no habían tenido etanol en la fase de tratamiento. 
Experimento 8: Efecto de la administración de deprenil (0 o $2.5 \mathrm{mg} / \mathrm{kg}$ ) en la sensibilización motora inducida por el etanol

La Figura 8 nos muestra la no interacción del deprenil ( $\left.\begin{array}{lll}0 & \text { o } 2.5 \mathrm{mg} / \mathrm{kg}\end{array}\right)$ con la sensibilización motora inducida por el etanol. Un ANOVA de medidas repetidas dio que en la fase de tratamiento el factor significativo fue el etanol $[F(1,26)=47.46$, $\mathrm{p}<0.01]$ pero no hubo efecto por la administración de deprenil. El día del test los animales que habían recibido etanol mostraron la adquisición de la sensibilización inducida por esta droga al resultar diferencias significativas con los grupos a los que se les administró salina, en ambos casos $\mathrm{p}<0.05$.

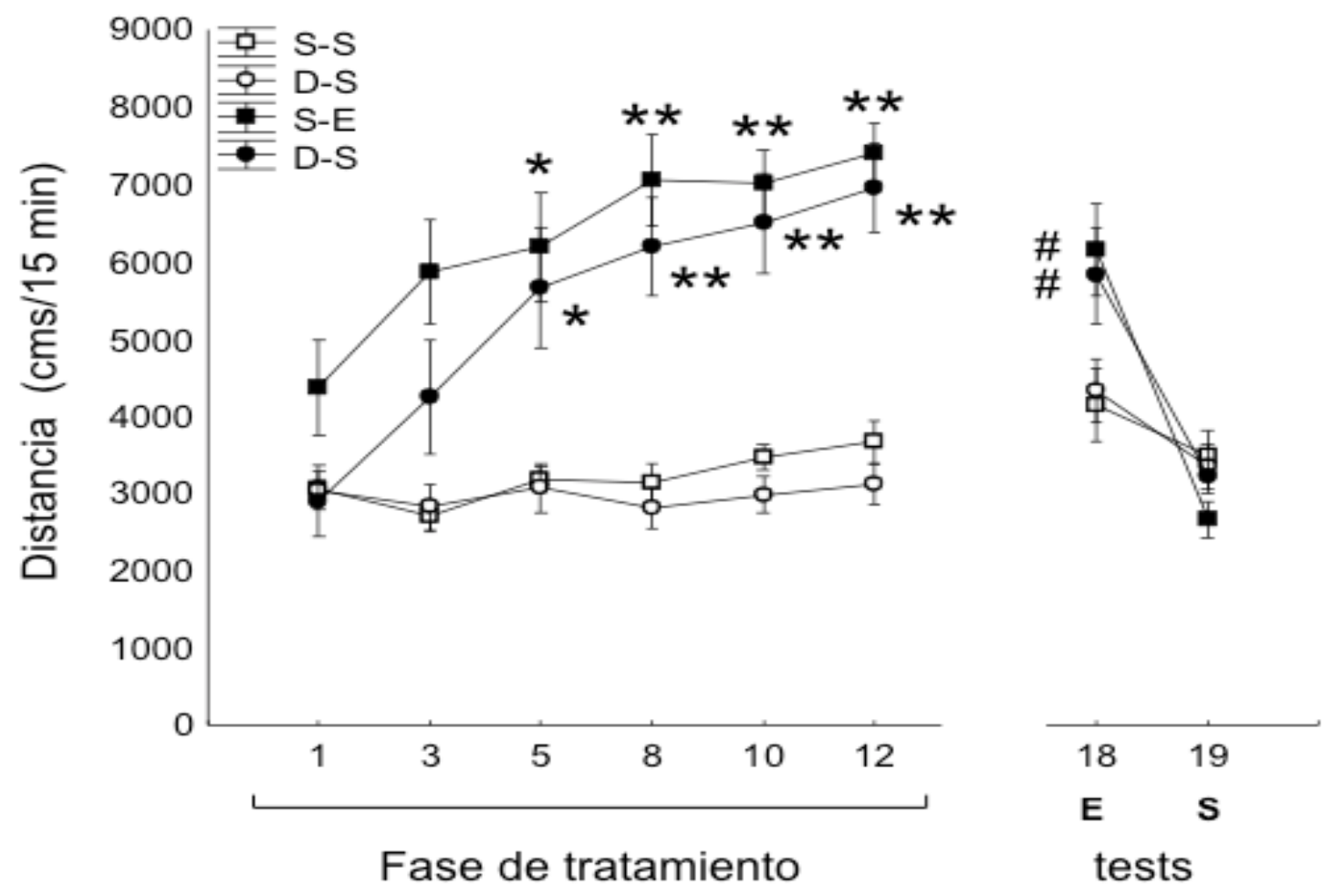

Figura 8: Efecto del deprenil $(2,5 \mathrm{mg} / \mathrm{kg})$ o salina sobre la sensibilización motora producida por etanol ( 0 o $2.5 \mathrm{~g} / \mathrm{kg}$ ). ${ }^{*} p<0.05$ respecto al primer día de su grupo.** $p<0.01$ respecto al primer día de su grupo. \# $p<0.05$ respecto a los grupos que no habían tenido etanol en la fase de tratamiento. 


\subsection{EXPERIMENTOS SOBRE EL CONSUMO VOLUNTARIO DE ETANOL}

Experimento 9: Efecto de la clorgilina (0 o $5 \mathrm{mg} / \mathrm{kg}$ ) sobre la ingesta voluntaria de etanol

Las Figuras 9 (a y b) muestran el efecto de la clorgilina (0 o $5 \mathrm{mg} / \mathrm{kg}$ ) en la ingesta voluntaria de etanol durante 120 o 240 minutos, en un paradigma de acceso restringido al etanol $(20 \% \mathrm{v} / \mathrm{v})$. Un ANOVA con el factor clorgilina (0 o $5 \mathrm{mg} / \mathrm{kg}$ ) mostró un efecto significativo de la clorgilina sobre la cantidad de etanol ingerida por los animales $(\mathrm{g} / \mathrm{kg})$ tanto en los primeros $120 \mathrm{~min}[\mathrm{~F}(1,28)=12.94, \mathrm{p}<0.01]$ cómo en 240 minutos $[\mathrm{F}(1,28)=9.05, \mathrm{p}<0.01]$. En ambos casos la administración de $10 \mathrm{mg} / \mathrm{kg}$ de clorgilina 30 minutos antes de ponerles las botellas de etanol supuso una disminución en la cantidad de etanol ingerida. Estos resultados sugieren que la clorgilina reduce el consumo de etanol en estas condiciones.

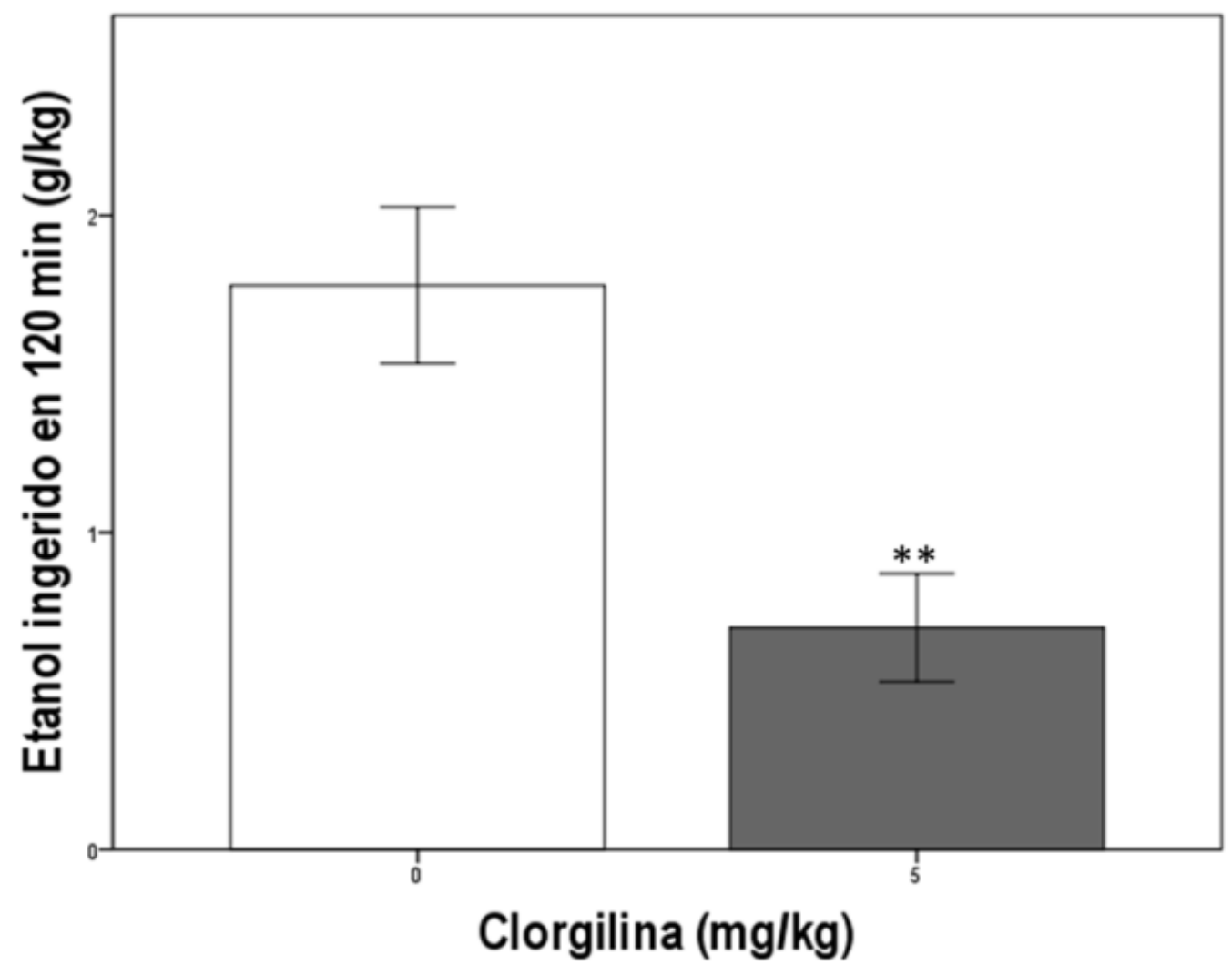

Figura 9a: Efecto de la clorgilina (0 o $5 \mathrm{mg} / \mathrm{kg}$ ) sobre la ingesta voluntaria de etanol al $20 \%(\mathrm{v} / \mathrm{v})$ en 120 minutos. ${ }^{* *} p<0.01$ respecto al grupo clorgilina $0 \mathrm{mg} / \mathrm{kg}$. 




Figura 9b: Efecto de la clorgilina (0 o $5 \mathrm{mg} / \mathrm{kg}$ ) sobre la ingesta voluntaria de etanol al $20 \%(\mathrm{v} / \mathrm{v})$ en 240 minutos. ${ }^{* *} \mathrm{p}<0.01$ respecto al grupo clorgilina $0 \mathrm{mg} / \mathrm{kg}$.

Experimento 10: Efecto de la clorgilina (0 o $5 \mathrm{mg} / \mathrm{kg}$ ) sobre la ingesta voluntaria de agua

En la Figura 10 (a y b) se pueden ver los efectos de la administración de clorgilina (0 o $5 \mathrm{mg} / \mathrm{kg}$ ) sobre la ingesta voluntaria de agua. Como se puede comprobar no hubo ningún efecto sobre la ingesta de agua. 


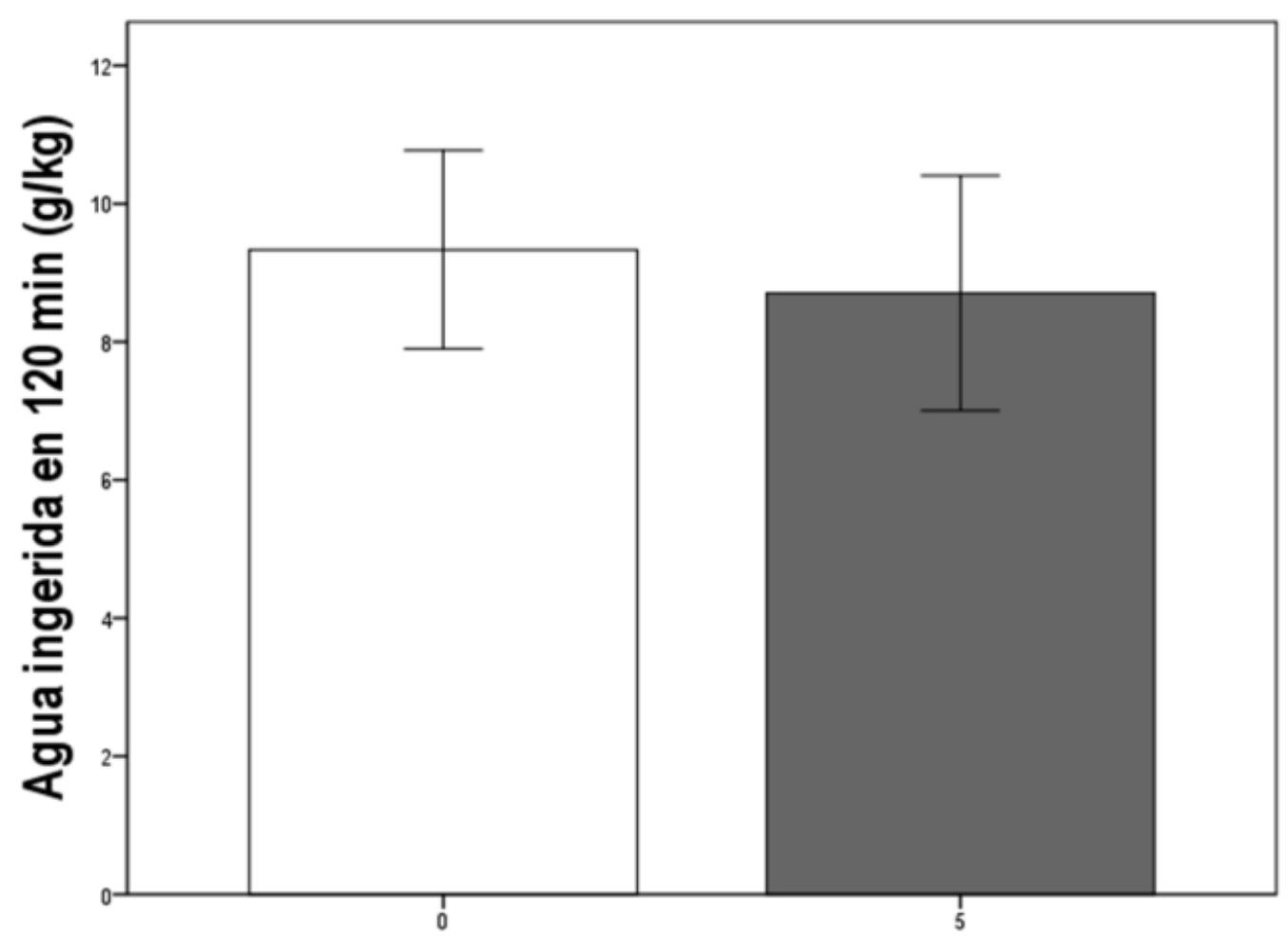

Clorgilina (mg/kg)

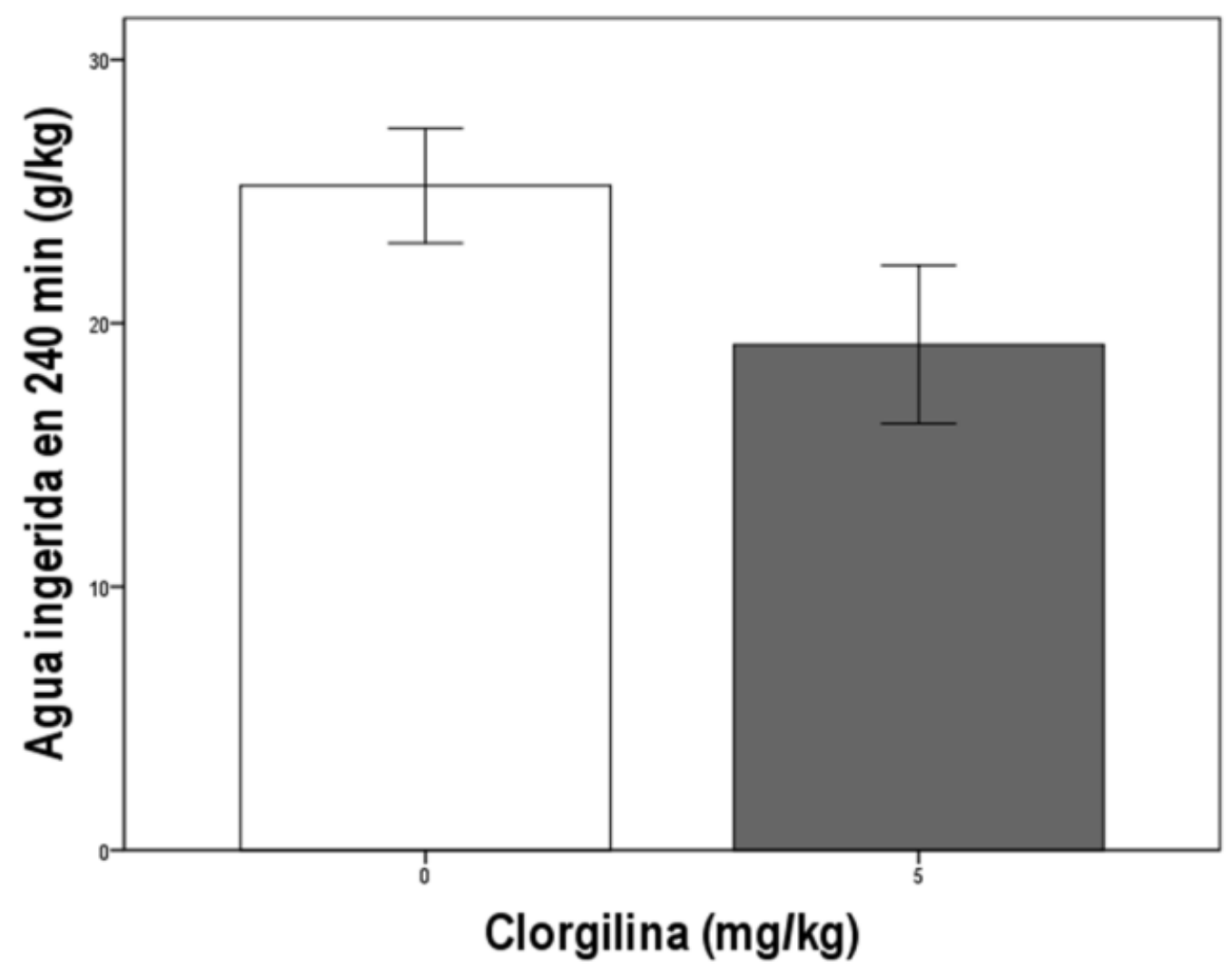

Figura 10: Efecto de la clorgilina (0 o $5 \mathrm{mg} / \mathrm{kg}$ ) sobre la ingesta voluntaria de agua: a) en 120 minutos, b) en 240 minutos. 
Experimento 11: Efecto de la clorgilina (0 o $5 \mathrm{mg} / \mathrm{kg}$ ) sobre la ingesta voluntaria de sacarina

En la Figura 11 (a y b) se puede apreciar que no hubo ningún efecto de la administración de clorgilina (0 o $5 \mathrm{mg} / \mathrm{kg}$ ) sobre la ingesta voluntaria de sacarina, ni en 120 minutos ni tampoco en 240 minutos.

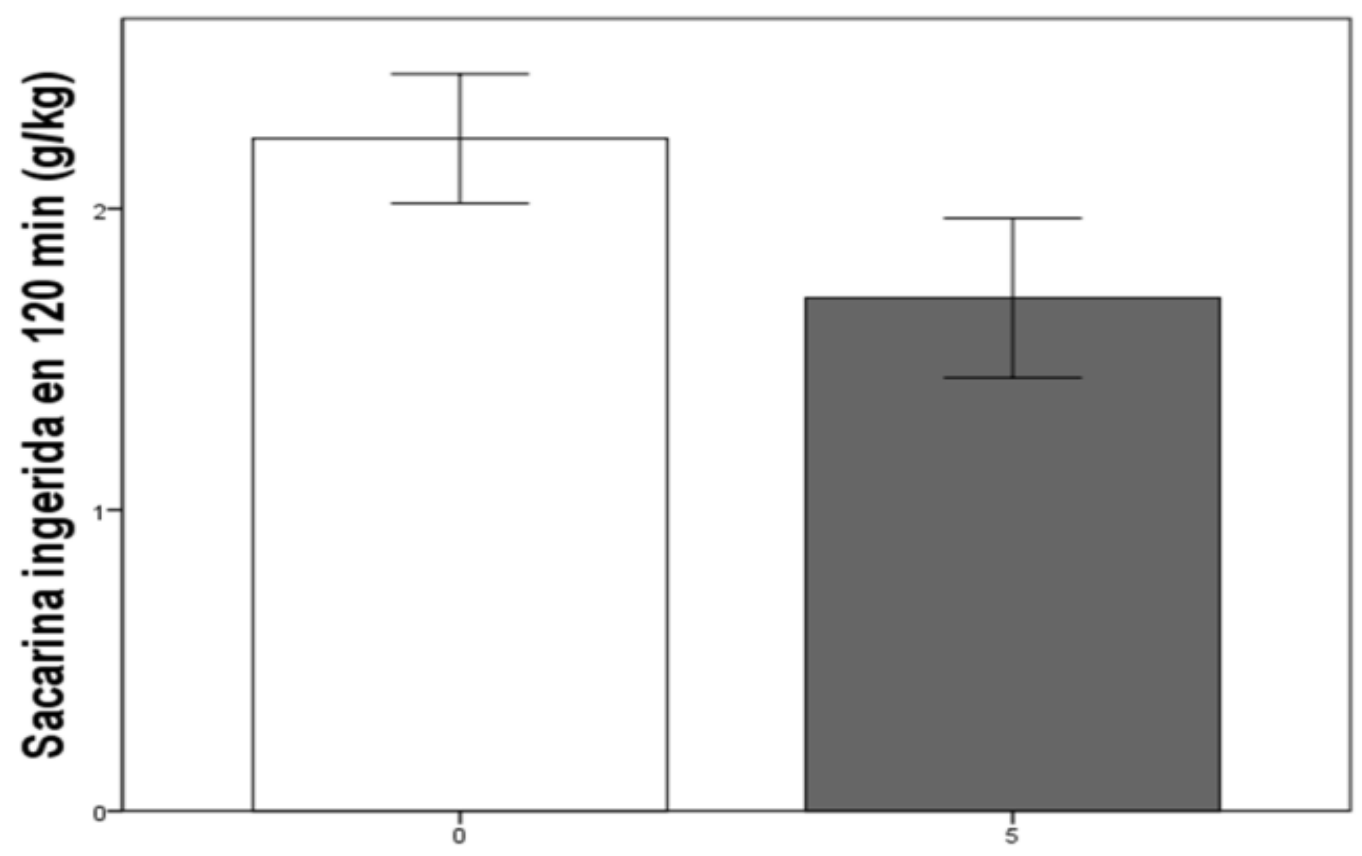

Clorgilina (mg/kg)

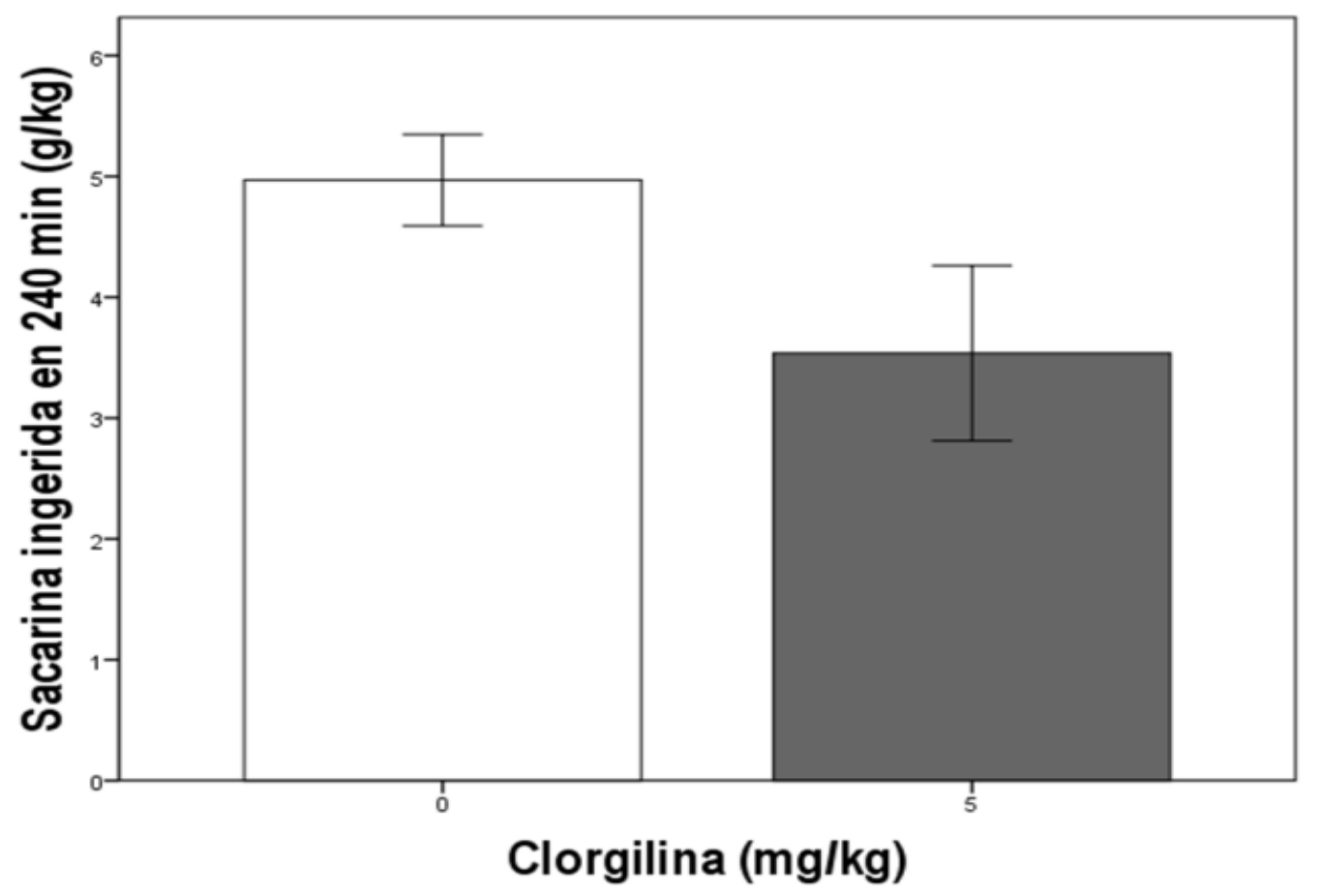

Figura 11: Efecto de la clorgilina (0 o $5 \mathrm{mg} / \mathrm{kg}$ ) sobre la ingesta voluntaria de sacarina): a) en 120 minutos, b) en 240 minutos. 
Experimento 12: Efecto del deprenil (lo o $2.5 \mathrm{mg} / \mathrm{kg}$ ) sobre la ingesta voluntaria de etanol

La Figura 12 (a y b) muestra el efecto de la administración de deprenil ( 0 o 2.5 $\mathrm{mg} / \mathrm{kg}$ ) en la ingesta voluntaria de etanol ( $20 \% \mathrm{v} / \mathrm{v}, \mathrm{g} / \mathrm{kg})$. Un ANOVA con el factor deprenil ( 0 o $2.5 \mathrm{mg} / \mathrm{kg}$ ) y la variable dependiente la cantidad de etanol ingerida $(\mathrm{g} / \mathrm{kg})$ en 120 minutos no hubieron diferencias significativas, pero si las hubieron en 240 minuto $[F(1,25)=9.74, p<0.01]$.
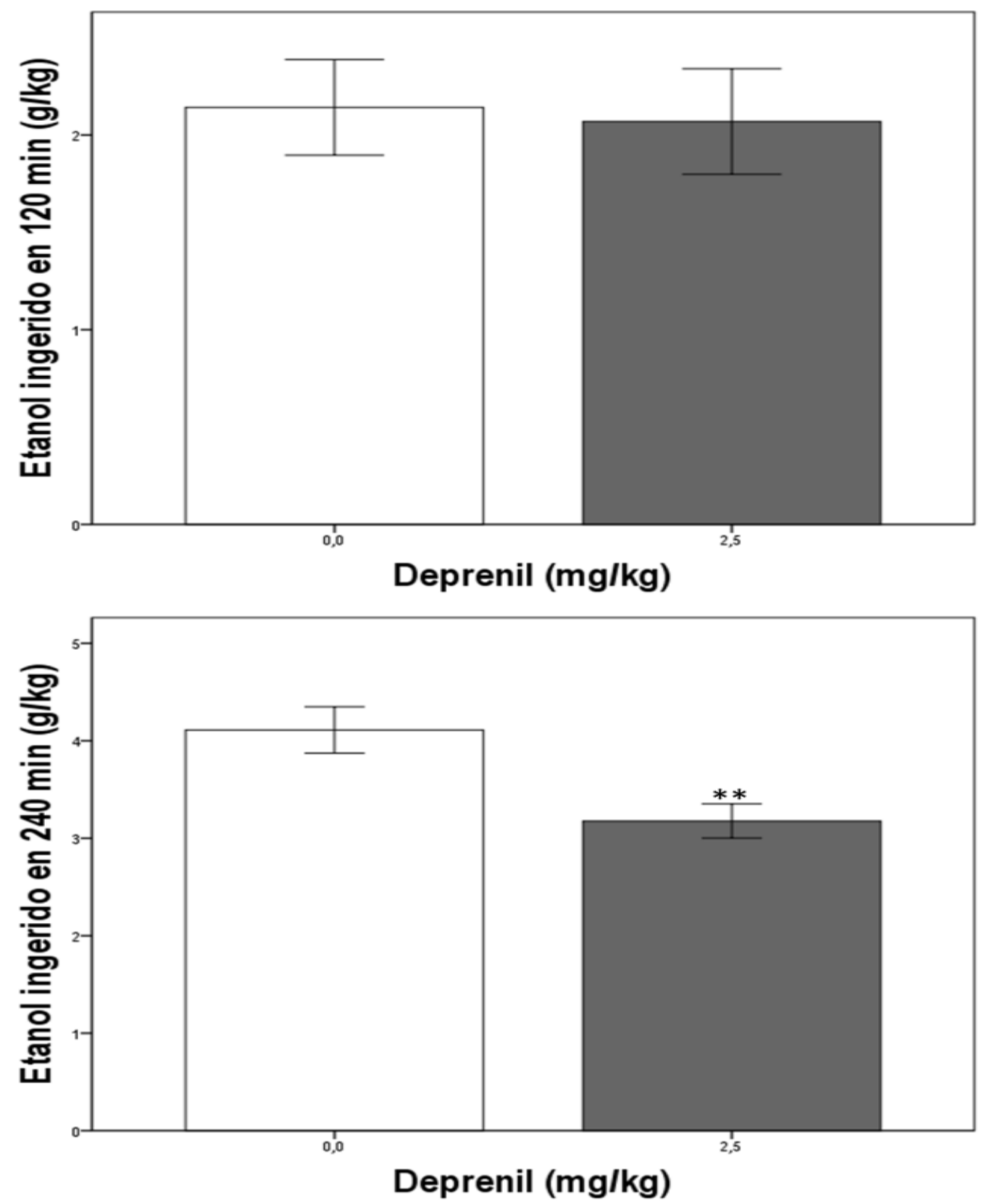

Figura 12: Efecto del deprenil (0 o $2.5 \mathrm{mg} / \mathrm{kg}$ ) sobre la ingesta voluntaria de etanol al 20\%(v/v): a) en 120 minutos, b) en 240 minutos. ${ }^{* *} p<0.01$ respecto al grupo clorgilina 0 $\mathrm{mg} / \mathrm{kg}$. 
Experimento 13: Efecto del deprenil (0 o $2.5 \mathrm{mg} / \mathrm{kg}$ ) sobre la ingesta voluntaria de agua

La Figura 13 (a y b) muestra que no hubo efecto del deprenil ( 0 o $2.5 \mathrm{mg} / \mathrm{kg}$ ) sobre la ingesta voluntaria de agua ni en 120 ni en 240 minutos.
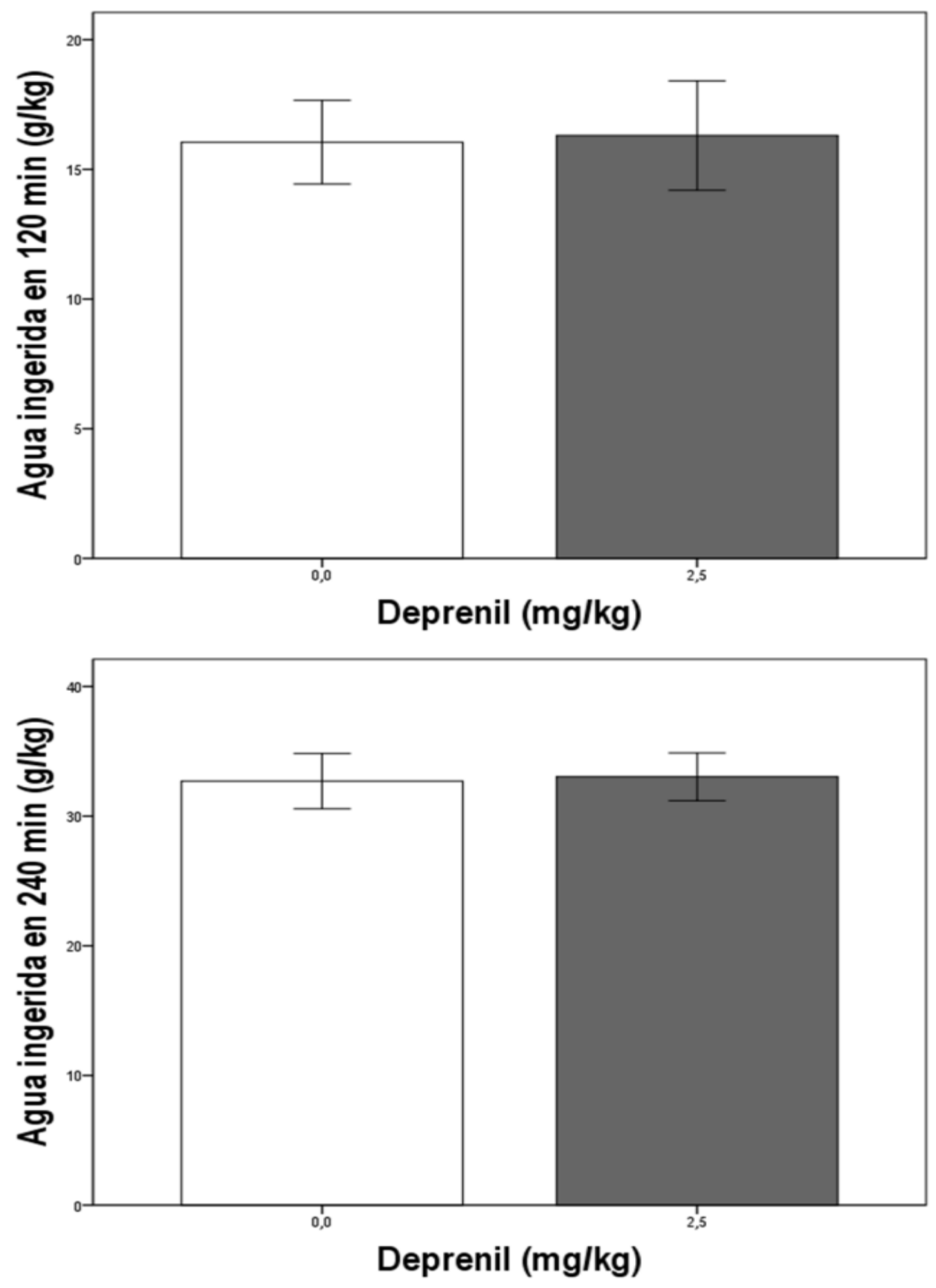

Figura 13: Efecto del deprenil (0 o $2.5 \mathrm{mg} / \mathrm{kg}$ ) sobre la ingesta voluntaria de agua: a) en 120 minutos, b) en 240 minutos. 
Experimento 14: Efecto del deprenil (lo o $2.5 \mathrm{mg} / \mathrm{kg}$ ) sobre la ingesta voluntaria de sacarina

Como se puede ver en la Figura 14 (a y b) no hubo ningún efecto de la administración de deprenil ( $\left.\begin{array}{lll}0 & \text { o } & 2.5 \mathrm{mg} / \mathrm{kg}\end{array}\right)$ sobre la ingesta de sacarina en un paradigma de acceso restringido.
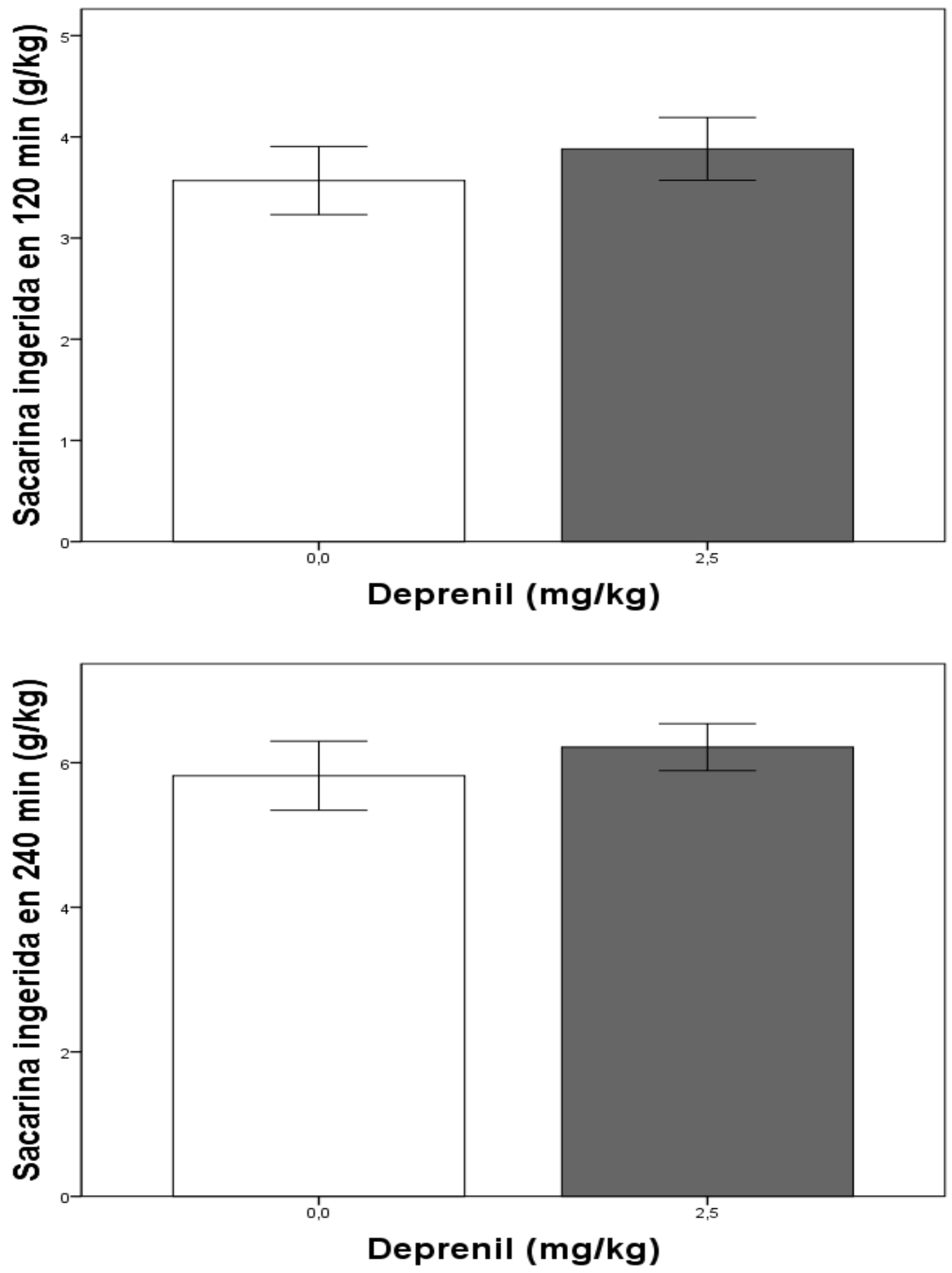

Figura 14: Efecto del deprenil (0 o $2.5 \mathrm{mg} / \mathrm{kg}$ ) sobre la ingesta voluntaria de sacarina: a) en 120 minutos, b) en 240 minutos. 


\subsection{EXPERIMENTOS SOBRE LA ACTIVIDAD ENZIMÁTICA DE LA CATALASA}

Experimento 15: Efecto de la clorgilina y el deprenil sobre la actividad enzimática de la catalasa

En la Tabla 1 se puede apreciar la acción de la clorgilina ( 0 o $10 \mathrm{mg} / \mathrm{kg}$ ) y del amino triazol (AT, 0, $0.5 \circ 1 \mathrm{~g} / \mathrm{kg}$ ) sobre la actividad enzimática de la catalasa. Un ANOVA de dos factores [dosis de clorgilina (0 o $10 \mathrm{mg} / \mathrm{kg}$ ) x dosis de AT $(0,0.5$ o 1 $\mathrm{g} / \mathrm{kg})]$ reveló un efecto de la clorgilina $[\mathrm{F}(1,28)=23.65, \mathrm{p}<0.01]$ así como el efecto del AT $[F(2,28)=22.24, p<0.01]$, pero no mostró efecto significativo de la interacción de ambos ( $\mathrm{p}>0.3$ ). Como se puede ver en la Tabla 1, el deprenil (0 o 5 $\mathrm{mg} / \mathrm{kg}$ ) y el AT (0, 0.5 o $1 \mathrm{~g} / \mathrm{kg})$ también afectaron la actividad enzimática de la catalasa. El ANOVA [dosis de deprenil ( 0 o $10 \mathrm{mg} / \mathrm{kg}$ ) x dosis de AT (0, 0.5 o 1 $\mathrm{g} / \mathrm{kg})]$ reveló un efecto significativo del deprenil $[\mathrm{F}(1,30)=4.60, \mathrm{p}<0.05]$, del AT $[F(2,30)=61.52, p<0.01]$ y también de la interacción entre ambos $[F(2,30)=7.30, p$ $<0.01]$. Estos resultados indican que tanto la clorgilina como el deprenil al inhibir la MAO disminuyen el peróxido de hidrogeno presente haciendo que se forme menos compuesto I (catalasa- $\mathrm{H}_{2} \mathrm{O}_{2}$ ), por lo que el AT no puede disminuir la actividad enzimática de la catalasa. Únicamente el deprenil con la dosis más alta de AT no pudo bloquear la inhibición de la actividad de la enzima catalasa.

Tabla 1: Efecto de la clorgilina (0 o $10 \mathrm{mg} / \mathrm{kg}$ ) y el deprenil (0 o $10 \mathrm{mg} / \mathrm{kg}$ ) sobre la inhibición de la actividad enzimática de la catalasa producida por el AT $(0,0.5$ o $1 \mathrm{~g} / \mathrm{kg}) .{ }^{* *} p<0.01$ con respecto al grupo clorgilina o deprenil $0 \mathrm{mg} / \mathrm{kg}$ y AT $0 \mathrm{~g} / \mathrm{kg}$. \#\# $p<0.01$ con respecto al grupo deprenil 10 $\mathrm{mg} / \mathrm{kg}$ y $A T$ O $\mathrm{g} / \mathrm{kg}$.

\begin{tabular}{ccc} 
Clorgilina $(\mathrm{mg} / \mathrm{kg})$ & AT $(\mathrm{g} / \mathrm{kg})$ & $\begin{array}{c}\text { Actividad de la catalasa } \\
\text { (nmol/mg/min) }\end{array}$ \\
\hline 0 & 0,0 & $1,13 \pm 0,19$ \\
0 & 0,5 & $0,86 \pm 0,07^{* *}$ \\
0 & 1,0 & $0,66 \pm 0,07^{* *}$ \\
10 & 0,0 & $1,15 \pm 0,12$ \\
10 & 0,5 & $1,09 \pm 0,12$ \\
10 & 1,0 & $0,95 \pm 0,12$ \\
& & \\
Deprenil $(\mathrm{mg} / \mathrm{kg})$ & AT (g/kg) & Actividad de la catalasa \\
& & (nmol $/ \mathrm{mg} / \mathrm{min})$ \\
\hline 0 & 0,0 & $1,36 \pm 0,06$ \\
0 & 0,5 & $0,90 \pm 0,22^{* *}$ \\
10 & 1,0 & $0,68 \pm 0,11^{* *}$ \\
10 & 0,0 & $1,26 \pm 0,04$ \\
& 0,5 & $1,16 \pm 0,13$
\end{tabular}




\subsection{EXPERIMENTOS SOBRE LOS NIVELES DE ETANOL EN SANGRE}

Experimento 16: Efecto de la clorgilina y el deprenil sobre la actividad metabólica y la absorción periférica del etanol

En la Tabla 2 se observa como ni la clorgilina (5 mg/kg) ni el deprenil (2,5 mg/kg) tienen efecto sobre la absorción y/o el metabolismo periférico del etanol. Lo cual indica que estas sustancias no modifican la absorción ni el metabolismo periférico del etanol.

Tabla 2: Concentración de etanol en sangre (media \pm error estándar). Efecto de la clorgilina (0 o 5 $\mathrm{mg} / \mathrm{kg}$ ) y el deprenil ( 0 o 2,5 mg/kg) sobre la absorción y/o el metabolismo periférico del etanol.

Time (minutes)

\begin{tabular}{ccc} 
Clorgilina $(\mathrm{mg} / \mathrm{kg})$ & 10 & 20 \\
\hline 0 & $2,80 \pm 0,20$ & $3,01 \pm 0,14$ \\
5 & $2,54 \pm 0,26$ & $2,59 \pm 0,32$ \\
Deprenil (mg/kg) & \multicolumn{2}{c}{ Time (minutes) } \\
\hline 0 & $3,19 \pm 0,27$ & $3,25 \pm 0,19$ \\
2,5 & $3,51 \pm 0,14$ & $3,13 \pm 0,16$
\end{tabular}





\section{DISCUSIÓN}

En los experimentos de actividad locomotora (Experimentos del 1 al 6) que hemos llevado a cabo hemos demostrado que tanto la clorgilina como el deprenil son capaces de bloquear los efectos estimuladores que el etanol induce sobre la actividad motora de manera dosis dependiente. Es decir, la actividad locomotora de los ratones tratados con una dosis de clorgilina de 5 o $10 \mathrm{mg} / \mathrm{kg}$ (30 minutos antes) o deprenil 2,5 o $5 \mathrm{mg} / \mathrm{kg}$ (4 horas antes) no se vio aumentada por la administración de una dosis de etanol de $2,5 \mathrm{~g} / \mathrm{kg}$, la cual estimula la actividad locomotora en ratones tratados con salina, en lugar de clorgilina o deprenil. Es interesante resaltar que estas dosis y tiempos de clorgilina y deprenil no provocan cambios en los patrones de actividad locomotora en el campo abierto como se puede observar con los grupos clorgilina $0 \mathrm{mg} / \mathrm{kg}$ - etanol $0 \mathrm{~g} / \mathrm{kg}$ que no difiere del grupo clorgilina $5 \mathrm{mg} / \mathrm{kg}$ - etanol $0 \mathrm{~g} / \mathrm{kg}$ y los grupos del deprenil que tampoco muestran diferencias entre deprenil $0 \mathrm{mg} / \mathrm{kg}$ - etanol $0 \mathrm{~g} / \mathrm{kg}$ con el grupo deprenil $2,5 \mathrm{mg} / \mathrm{kg}$ - etanol $0 \mathrm{~g} / \mathrm{kg}$.

Tampoco se produjeron cambios en la depresión motora inducida por dosis elevadas de etanol $(3,75 \mathrm{~g} / \mathrm{kg})$ como se desprende de los resultados de los grupos clorgilina $0 \mathrm{mg} / \mathrm{kg}$ - etanol 3,75 g/kg que no se diferencia del grupo clorgilina 5 $\mathrm{mg} / \mathrm{kg}$ - etanol 3,75 g/kg y de los grupos tratados con deprenil, es decir el grupo deprenil $0 \mathrm{mg} / \mathrm{kg}$ - etanol 3,75 g/kg no difiere del grupo deprenil 2,5 mg/kg- etanol $3,75 \mathrm{~g} / \mathrm{kg}$, lo que demostraría que no se trata de un efecto inespecífico de estos tratamiento sobre la locomoción. Además la actividad locomotora inducida por otras drogas como la anfetamina, cocaína o cafeína no fueron alteradas ni por el tratamiento con clorgilina $5 \mathrm{mg} / \mathrm{kg}$ ni por el deprenil 2,5 mg/kg, en nuestras condiciones experimentales, lo que indicaría que estas estrategias farmacológicas serían especificas para la inducción de la locomoción que produce el etanol.

En relación a los Experimentos de sensibilización (7 y 8), cabe destacar que ni la clorgilina ni el deprenil fueron capaces al menos a las dosis utilizadas de bloquear la sensibilización al etanol, esto nos podría indicar que además de la influencia del compuesto I sobre la actividad locomotora inducida por etanol 
podría haber otros sistemas enzimáticos, como pudiese ser le MEOS (sistema microsomal de oxidativo) y, como vimos en la introducción, el CYP450 2E1 que tomaría un papel más importante con cada administración de etanol que reciben los animales.

Además como se puede apreciar con los experimentos de ingesta voluntaria de diversas soluciones en un paradigma de acceso restringido como el que se utilizó en los Experimentos del 9 al 14, los inhibidores irreversibles de la monoamino oxidasa A (clorgilina) y de la MAO-B (deprenil), se desprende que estos compuestos no afectan a la ingesta voluntaria ni del agua ni de la sacarina, mientras que la clorgilina provoca una disminución significativa de la cantidad de etanol ingerida tanto en 120 minutos como en 240 minutos y el deprenil provoca la disminución significativa del consumo de alcohol únicamente a los 240 minutos, no resultando significativa la diferencia a los 120 minutos. Estos resultados estarían en concordancia con artículos anteriores que utilizaron estos compuestos, en los que se halló una reducción en la cantidad de etanol ingerida por ratas que fueron expuestas a diferentes paradigmas de ingesta voluntaria de etanol (Cohen y cols., 1999; Mega y cols., 2002). Para Mega y cols. (2002) el deprenil no tuvo efecto sobre el consumo de alcohol de las ratas lo que podría ser debido a varias cuestiones, entre ellas el hecho de que las ratas tuvieran un acceso libre al etanol y al agua al mismo tiempo o a que para sus experimentos se utilizaron ratas seleccionadas genéticamente como consumidoras de etanol o sufrieron una inducción química, mediante cianamida administrada diariamente, al consumo del etanol.

Un primer estudio bioquímico (Experimento 15) tuvo como fin demostrar que estos compuestos son capaces de reducir los niveles de peróxido de hidrógeno en homogenados cerebrales y como consecuencia bloquear la inhibición del compuesto I que ejerce el AT, como se puede ver en la Tabla 1 de los resultados, los homogenados cerebrales de ratones que recibieron clorgilina o deprenil (10 $\mathrm{mg} / \mathrm{kg}$ en ambos casos) y después se les administro AT $(0,5$ o $1 \mathrm{~g} / \mathrm{kg})$ tuvieron una actividad de la catalasa significativamente mayor que los ratones que recibieron salina y AT (0,5 o $1 \mathrm{~g} / \mathrm{kg})$. Lo cual es indicativo de que los inhibidores de la 
monoamino oxidasa reducen los niveles de peróxido de hidrógeno presentes en los homogenados cerebrales ya que impiden que el AT inhiba a la catalasa ya que el AT necesita $\mathrm{H}_{2} \mathrm{O}_{2}$ para poder inhibir esta enzima.

Un segundo estudio bioquímico (Experimento 16) que hemos realizado ha tenido como fin comprobar que estos compuestos no modifican la absorción o el metabolismo periférico del etanol como queda demostrado con los datos obtenidos (Tabla 2 de los resultados). Como se ha comentado con anterioridad la desaminación de las aminas biogénicas mediante las monoamino oxidasas (A y B) provocan la aparición de peróxido de hidrógeno en el sistema nervioso central, como subproducto de la reacción. Este $\mathrm{H}_{2} \mathrm{O}_{2}$ en el SNC ha sido señalado por diversos autores como mediador en varias conductas inducidas por el etanol, como puede ser la estimulación de la actividad locomotora inducida por el alcohol en ratones (Ledesma y Aragon, 2012; Ledesma y cols., 2012; Manrique y cols., 2006; Pastor y cols., 2002). Más concretamente, la exposición de los roedores a tratamientos que aumentan los niveles de peróxido de hidrógeno en el sistema nervioso central ejerce un aumento de la actividad locomotora inducida por el etanol (Manrique y cols., 2006; Pastor y cols., 2002). Por el contrario, si reducimos los niveles de $\mathrm{H}_{2} \mathrm{O}_{2}$ mediante ácido lipoico o ebselen la actividad locomotora inducida por etanol disminuye de manera dosis dependiente (Ledesma y Aragon, 2012; Ledesma y cols., 2012). Además, tanto el LA como el ebselen, compuestos que son secuestradores del peróxido de hidrógeno, han demostrado que su administración disminuye el consumo voluntario de alcohol en ratones (Ledesma y cols., 2014a). Teniendo en cuenta todos estos datos, es posible considerar que la reducción en la actividad locomotora inducida por etanol y el consumo voluntario de alcohol tras la administración de clorgilina o deprenil, que hemos constatado en los experimentos de esta tesis doctoral, pudiese ser debida a la reducción de los niveles de $\mathrm{H}_{2} \mathrm{O}_{2}$ en el sistema nervioso central. Los hallazgos de estos experimentos están en concordancia con resultados anteriores en los que la cantidad de peróxido de hidrógeno presente en el SNC pueden tener un papel principal en la mediación de los efectos psicofarmacológicos del etanol, y representan una prolongación de los estudios previos. Nuestra hipótesis es que la producción de $\mathrm{H}_{2} \mathrm{O}_{2}$ que proviene de la desaminacion de las aminas biogénicas 
metabolizadas por la monoamino oxidasa pudiera ser una fuente importante de peróxido de hidrógeno a través del cual el etanol ejerce sus acciones neuroconductuales.

Como hemos visto con anterioridad, el etanol es metabolizado a acetaldehído en el cerebro principalmente por la actividad del sistema catalasa- $\mathrm{H}_{2} \mathrm{O}_{2}$ (compuesto I) (Aragon y cols., 1992; Gill y cols., 1992; Hamby-Mason y cols., 1997, Zimatkin y Buben, 2007). Se ha demostrado que los homogenados de cerebro y cultivos de tejidos cerebrales pueden producir acetaldehído si son incubados con etanol, y que homogenados cerebrales de rata que habían sido tratadas con AT, cianamida sódica o azida sódica mostraron una reducción en la formación del acetaldehído que las ratas que no fueron tratadas con estos compuestos (Aragon y cols., 1992; Gill y cols., 1992; Hamby-Mason y cols., 1997). Además, la adición de compuestos capaces de aumentar los niveles de peróxido de hidrógeno en estas preparaciones in vitro produjeron un aumento de la producción de acetaldehído (Aragon y cols., 1992; Gill y cols., 1992). También ha sido demostrado que la administración de AT, cianamida sódica o azida sódica reduce la cantidad de acetaldehído detectado por medio de microdiálisis en el estriado de ratas, que podían moverse libremente, a las que se les administro etanol intraperitonealmente (Jamal y cols., 2007). Igualmente, parece que tanto la actividad de la catalasa como la disponibilidad de peróxido de hidrógeno en el cerebro determinan la capacidad del compuesto I para metabolizar el etanol e en acetaldehído en el SNC. Como se ha visto con anterioridad el AT únicamente es capaz de inhibir la actividad de la catalasa cuando la enzima ha reaccionado con el $\mathrm{H}_{2} \mathrm{O}_{2}$ para formar el compuesto I (Aragon y cols., 1992; Margoliash y cols., 1960; Tephly y cols., 1961; Yusa y cols., 1987). Es decir, el efecto que sobre la actividad de la enzima catalasa ejerce el AT puede ser utilizado como medida indirecta de la capacidad de esta enzima para formar el compuesto I. Como hemos visto en el Experimento 15, tanto la clorgilina como el deprenil han sido capaces de bloquear la reducción de la actividad de la catalasa que provoca el AT. Lo cual, indicaría que la clorgilina y el deprenil provocan un descenso en los niveles de peróxido de hidrógeno produciendo una reducción en la formación del compuesto I. Y como consecuencia, cuando los animales son expuestos al etanol, la cantidad de 
acetaldehído derivado del metabolismo encefálico del alcohol será inferior en los ratones tratados con clorgilina o deprenil.

Por lo que respecta a la sensibilización producida por etanol nuestros resultados muestran que ninguno de los 2 inhibidores de la monoamino oxidasa bloquean la sensibilización. El estudio de Ledesma y cols. (2014b) nos demuestran que ratones a los que se les indujo la actividad del CYP450 2E1 mediante la administración crónica de acetona tuvieron un incremento de la actividad locomotora inducida por etanol, pero no por otras sustancias psicoestimulantes como la anfetamina o el ter-butanol, además estas manipulaciones en los ratones tampoco provocaron alteraciones motoras evaluadas mediante el rota-rod. Como se ha visto, la administración crónica de etanol induce la actividad del CYP450 2E1 pudiendo llegar a tener un papel importante en el metabolismo del etanol a acetaldehído (Gill y cols., 1992; Montoliu y cols., 1994; Vasiliou y cols., 2006). Por lo tanto nuestros resultados de los Experimentos 7 y 8 pudieran ser debidos a la inducción de la actividad del CYP450 2E1 por la administración crónica del etanol.

Los resultados obtenidos tanto para la actividad locomotora inducida por etanol como para el consumo voluntario de alcohol, en este trabajo, son coincidentes con estudios previos, lo que nos indicaría que la producción de acetaldehído en el SNC mediada por el compuesto I esta implicada en la estimulación motora inducida por etanol y su consumo voluntario (Escarabajal y cols., 2000; Font y cols., 2005, 2006b; Koechling y Amit, 1994; Martí-Prats y cols., 2010; Peana y cols., 2010). Cabe destacar que lo más interesante es que parece que la formación de acetaldehído dentro de las neuronas del sistema catelocolaminérgico podrían tener una relevante implicación en las conductas inducidas por etanol. Dado que se conoce que la catalasa cerebral se expresa selectivamente en las neuronas del sistema aminérgico en roedores (Diana y cols., 2008; Moreno y cols., 1995; Schad y cols., 2003; Zimatkin y Lindros, 1996), y teniendo en cuenta que la desaminización de las aminas biogénicas metabolizadas por la monoamino oxidasa producen como subproducto peróxido de hidrógeno (Bortolato y cols., 2008, 2011; Fitzgerald y cols., 2007; Hermida-Ameijeiras y cols., 2004; Pizzinat y cols., 1999; Spina y Cohen, 1989). Lo que proponemos es que 
tanto la clorgilina como el deprenil reducen significativamente los niveles de peróxido de hidrógeno en este circuito neuronal mediante la inhibición de la MAO. Igualmente, proponemos que como resultado del acetaldehído derivado del metabolismo encefálico del etanol poducido por el compuesto I en esta región neuroanatómica pudiera ser un posible mediador de algunas de las conductas que hemos probado en este trabajo.

Hay diferentes explicaciones a estos resultados que deberían ser tenidas en cuenta. Esta bien documentado que el etanol en el sistema nervioso central interacciona con la DA, 5-HT, A y NA (Nutt, 1999; Sari, 2013; Sirca y cols., 2011). La inhibición de la monoamino oxidasa elevaría los niveles de estos neurotransmisores disponibles en las uniones sinápticas (Kitanaka y cols., 2005, 2006, 2010; Volz y Gleiter, 1998). Debido a esto se podría especular con la posibilidad de que esta inhibición de la MAO bloqueara la actividad locomotora inducida por etanol mediante la reducción de la actividad enzimática de la monoamino oxidasa, y por consiguiente mediante una alteración en la captación de A, NA, 5-HT y DA.

Sin embargo, nuestros estudios de selectividad muestran que los resultados obtenidos para la actividad locomotora inducida por etanol no son reproducidos cuando cambiamos el etanol por otras drogas psicoestimulantes como la cafeína, cocaína o anfetamina, que esta demostrado que ejerce su acción activadora de la locomoción mediante la interacción con estas aminas biogénicas (Caine y cols., 2012; Chiu y Schenk, 2012; Craige y Unterwald, 2012; Ferré, 2008; Filip y cols., 2010; Otis y Muller, 2011; Pockros y cols., 2012; Sulzer y cols., 2005). Además, si la modulación de la actividad locomotora inducida por etanol que observamos en este trabajo se debiese únicamente a la reducción en la recaptación de DA, NA, A y 5-HT, por la administración de clorgilina o deprenil, deberíamos observar un descenso similar en la actividad locomotora con la cafeína, anfetamina y cocaína. Los resultados obtenidos muestran que la clorgilina y el deprenil, al menos en las dosis que hemos usado, no afectan a la estimulación motora que ejercen la cocaína, cafeína y anfetamina, invalidando la hipótesis de que el descenso de la locomoción 
inducida por el etanol fuera debida a la alteración en la captación de estos neurotransmisores.

Otra posibilidad que se podría valorar a la vista de los resultados de consumo voluntario de etanol en el paradigma de bebida de alcohol, sería que tanto la clorgilina como el deprenil pudieran afectar de manera inespecífica al sentido del sabor o del gusto, o a una alteración de alguna área cerebral o circuito de neurotransmisión implicados en el refuerzo y la motivación. Pero como demuestran los experimentos en los que se les da agua o sacarina para beber ninguno de las dos soluciones muestran diferencias entre los ratones que recibieron sal o clorgilina o deprenil, por lo que esta hipótesis quedaría invalidada.

Más posibilidades a tener en cuenta sería que estos compuestos, clorgilina y deprenil, tuvieran un efecto en la absorción o en el metabolismo periférico del etanol pero como vimos en el Experimento 16, estos compuestos no variaron las concentraciones de etanol en la sangre de los ratones.

En definitiva, proponemos que la reducción de la actividad del sistema catalasa- $\mathrm{H}_{2} \mathrm{O}_{2}$ es el principal mecanismo responsable de la interacción de los inhibidores de la monoamino oxidasa (tanto A como B) y los efectos sobre la actividad locomotora inducida por etanol así como de los efectos sobre la ingesta voluntaria del etanol. Los resultados obtenidos son la continuación de estudios previos en los que se ha demostrado que la modificación de los niveles de peróxido de hidrógeno disponibles en el cerebro pueden alterar algunas de las conductas inducidas por el etanol (Ledesma y Aragon, 2012, 2013; Ledesma y cols., 2012, 2014a; Manrique y cols., 2006; Pastor y cols., 2002). Hay que subrayar que estos son los primeros estudios en los que se modifica la posible fuente principal de producción de $\mathrm{H}_{2} \mathrm{O}_{2}$, que sería la desaminización de las aminas biogénicas por medio de la monoamino oxidasa A y B, necesaria para la formación del compuesto I y por consiguiente para producir acetaldehído a partir del etanol en el sistema nervioso central. Este acetaldehído formado centralmente podría ser el responsable de los efectos psicoactivos del etanol. 



\section{CONCLUSIONES}

1. La clorgilina disminuye la actividad locomotora inducida por etanol, pero no la depresión motora inducida por este.

2. El deprenil reduce la locomoción inducida por el alcohol, pero no la supresión motora.

3. La clorgilina no afecta a la estimulación motora que provocan otras drogas psicoestimulante como cafeína, cocaína o anfetamina.

4. El deprenil no afecta a la inducción de la actividad motora producida por la administración de diferentes drogas psicoestimulantes como cafeína, cocaína o anfetamina.

5. La clorgilina no afecta a la sensibilización locomotora inducida por etanol.

6. El deprenil no modifica la sensibilización motora al etanol.

7. La clorgilina disminuye la cantidad de etanol que ingieren voluntariamente los ratones.

8. El deprenil disminuye el consumo de alcohol en 4 horas pero no en 2 horas.

9. La clorgilina no modifica los patrones de consumo de agua ni de sacarina.

10. El deprenil no altera el consumo de agua ni de sacarina.

11. La clorgilina bloquea la inhibición del compuesto I por el AT.

12. El deprenil bloquea la inhibición que el AT produce en el compuesto I.

13. La clorgilina no afecta ni a la absorción ni al metabolismo periférico del etanol.

14. El deprenil no modifica la absorción ni el metabolismo periférico del alcohol 
15. La MAO (A y B) pudiera ser la fuente principal de peróxido de hidrógeno necesario para la formación del compuesto I y, a través de este, la formación central de acetaldehído derivado del etanol, que producirá las conductas inducidas por el etanol. 


\section{REFERENCIAS}

Aebi H (1974) Catalase. In: Bergmeyer, H.U. (Ed.), Methods of Enzimatics Analysis, vol. III. Verlag Chemie, pp. 273-286.

Alele PE, Devaud LL (2005) Differential adaptations in GABAergic and glutamatergic systems during ethanol withdrawal in male and female rats. Alcohol clin Expe Res. 29: 1027-1034.

Alexi T, Borlongan CV, Faull RL, Williams CE, Clark RG, Gluckman PD, Hughes PE (2000) Neuroprotective strategies for basal ganglia degeneration: Parkinson's and Huntington's diseases. Prog Neurobiol. 60: 409-470.

Allgaier C (2002) Ethanol sensitivity of NMDA receptors. Neurochem Int. 41: 377-382.

Amit Z, Aragon CMG (1988) Catalase activity measured in rats naive to ethanol correlates with later voluntary ethanolconsumption: possible evidence for a biological marker system of ethanol intake. Psychopharmacology (Berl). 95: 512-515.

Amit Z, Brown ZW, Rockman GE (1977) Possible involvement of acetaldehyde, norepinephrine and their tetrahydroisoquinoline derivatives in the regulation of ethanol self-administration. Druf Alcohol Depend. 2: 495-500.

Anandatheerthavarada HK, Shankar SK, Bhamre S, Boyd MR, Song BJ, Ravindranath V (1993) Induction of brain cytochrome P-450IIE1 by chronic ethanol treatment. Brain Res. 601: 279-285.

Anderson MC, Hasan F, McCrodden JM, Tipton KF (1993) Monoamine oxidase inhibitors and the cheese effect. Neurochem Res. 18: 1145-1149.

Anichtchik O, Sallinen V, Peitsaro N, Panula P (2006) Distinct structure and activity of monoamine oxidase in the brain of zebrafish (Danio rerio). J Comp Neurol. 498: 593610.

Aragon CMG, Amit Z (1992) The effect of 3-amino-1,2,4-triazole on voluntary ethanol consumption: evidence for brain catalase involvement in the mechanism of action. Neuropharmacology. 31: 709-712.

Aragon CMG, Amit Z (1993) Differences in ethanol-induced behaviors in normal and acatalasemic mice: systematic examination using a biobehavioral approach. Pharmacol Biochem Behav. 44: 547-554.

Aragon CMG, Pesold CN, Amit Z (1992a) Ethanol-induced motor activity in normal and acatalasemic mice. Alcohol. 9: 207-211.

Aragon CMG, Rogan F, Amit Z (1992b) Ethanol metabolism in rat brain homogenates by a catalase- $\mathrm{H}_{2} \mathrm{O}_{2}$ system. Biochem Pharmacol. 44: 93-98.

Aragon CMG, Sternklar, Amit Z (1985) A correlation between voluntary ethanol consumption and brain catalase activity in the rat. Alcohol 2: 353-356. 
Aragon CMG, Stotland LM, Amit Z (1991) Studies on ethanol-brain catalase interaction: evidence for central ethanol oxidation. Alcohol Clin Exp Res. 15: 165-169.

Arai R, Karasawa N, Kurokawa K, Kanai H, Horiike K, Ito A (2002) Differential subcellular location of mitochondria in rat serotonergic neurons depends on the presence and the absence of monoamine oxidase type B. Neuroscience. 114: 825-835.

Arizzi MN, Correa M, Betz AJ, Wisniecki A, Salamone JD (2003) Behavioral effects of intraventricular injections of low doses of ethanol, acetaldehyde, and acetate in rats: studies with low and high rate operant schedules. Behav Brain Res. 147: 203-210.

Arizzi-LaFrance MN, Correa M, Aragon CMG, Salamone JD (2006) Motor stimulant effects of ethanol injected into the substantia nigra pars reticulata: importance of catalasemediated metabolism and the role of acetaldehyde. Neuropsychopharmacology. 31: 997-1008.

Bach AW, Lan NC, Johnson DL, Abell CW, Bembenek ME, Kwan SW, Seeburg PH, Shih JC (1988) cDNA cloning of human liver monoamine oxidase A and B: molecular basis of differences in enzymatic properties. Proc Natl Acad Sci USA. 85: 4934-4938.

Bao X, Hui D, Naassila M, Michaelis EK (2001) Chronic ethanol exposure increases gene transcription of subunits of an N-methyl-D-asparpate receptor-like complex in cortical neurons in culture. Neurosci Lett. 315: 5-8.

Basavarajappa BS, Cooper TB, Hungund BL (1998) Chronic ethanol administration downregulates cannabinoid receptors in mouse brain synaptic plasma membrane. Brain Res. 793: 212-218.

Berry MD (2004) Mammalian central nervous system trace amines: pharmacologic amphetamines, physiologic neuromodulators. J Neurochem. 90: 257-271.

Bhagwat SV, Leelavathi BC, Shankar SK, Boyd MR, Ravindranath V (1995) Cytochrome P450 and associated monooxygenase activities in the rat an human spinal cord: induction, immunological characterization and immunocytochemical localization. Neuroscience. 68: 593-601.

Bilska A, Dubiel M, Sokolowska-Jezewicz M, Lorenc-Koci E, Wlodek L (2007) Alpha-lipoic acid differently affects the reserpine-induced oxidative stress in the striatum and prefrontal cortex of rat brain. Neuroscience. 146: 1758-71.

Binienda Z, Simmons C, Hussain S, Slikker W, Ali SF (1998) Effect of acute exposure to 3nitropropionic acid on activities of endogenous antioxidants in the rat brain. Neurosci Lett. 251: 173-176.

Boehm SL 2nd, Ponomarev I, Jennings AW, Whiting PJ, Rosahl TW, Garret EM, Blednov YA, Harris RA (2004) Gamma-Aminobutiric acid A receptor subunit mutant mice: new perspectives on alcohol actions. Biochem Pharmacol. 68: 1581-1602.

Boehm SL 2nd, Schafer GL, Phillips TJ, Browman KE, Crabbe JC (2000) Sensitivity to ethanol-induced motor incoordination in 5-HT(1B) receptor null mutant mice is taskdependent: implications for behavioral assessment of genetically altered mice. Behav Neurosci 114: 401-409. 
Bond PA, Cundall RL (1977) Properties of monoamine oxidase (MAO) in human blood platelets, plasma. Clin Chim Acta. 80: 317-326.

Bortolato M, Chen K, Shih JC (2008) Monoamine oxidase inactivation: from pathophysiology to therapeutics. Adv Drug Deliv Rev. 60: 1527-1533.

Bortolato M, Shih JC (2011) Behavioral outcomes of monoamine oxidase deficiency: Preclinical and clinical evidence. Int Rev Neurobiol. 2011 ; 100: 13-42.

Bortolato, M.; Chen, K.; Shih, JC (2010) The degradation of serotonin: role of MAO. In: Müller, CP.; Jacobs, BL., editors. Handbook of the Behavioral Neurobiology of Serotonin. Elsevier; Amsterdam: p. 203-218.

Boutet I, Tanguy A, Moraga D (2004) Molecular identification and expression of two nonP450 enzymes, monoamine oxidase $\mathrm{A}$ and flavin-containing monooxygenase 2, involved in phase I of xenobiòtic biotransformation in the Pacific oyster, Crassostrea gigas. Biochim Biophys Acta. 1679: 29-36.

Bradford MM (1976) Rapid and sensitive method for the quantification of microgram quantities of protein utilizing the principle of protein-dye binding. Analytical Biochemistry 72, 248-254.

Brodie MS, Pesold C, Appel SB (1999) Ethanol directly excites dopaminergic ventral tegmental area reward neurons. Alcohol Clin Exp Res. 23: 18 23: 1848-1852.

Brodie MS, Trifunovic RD, Shefner SA (1995) Serotonin potentiates ethanol-induced excitation of ventral tegmental area reward neurons. Alcohol Clin Exp Res. 23: 11391146.

Brown CS, Kent TA, Bryant SG, Gevedon RM, Campbell JL, Felthous AR, Barratt ES, Rose RM (1989) Blood platelet uptake of serotonin in episodic aggression. Psychiatry Res. 27: 512.

Brown ZW, Amit Z, Smith B (1979) Intraventricular self-administration of acetaldehyde but not ethanol, in naive laboratory rats. Psychopharmacology. 64: 271-276.

Brown ZW, Amit Z, Smith B (1980) Intraventricular self-administration of acetaldehyde and voluntary consumption of ethanol in rats. Behav Neural Biol. 28: 150-155.

Brunner HG, Nelen M, Breakefield XO, Ropers HH, Van Oost BA (1993) Abnormal behavior associated with a point mutation in the structural gene for monoamine oxidase A. Science. 262: 578-580.

Buck KJ, Harris RA (1991) Neuroadaptive responses to chronic ethanol. Alcoholism. 15: 460-470.

Buller AL, Larson HC, Morrisett RA, Monaghan DT (1995) Glycine modulates ethanol inhibition of heteromeric N-methyl-D-aspartate receptors expressed in Xenopus oocytes. Mol Pharmacol. 48: 717-723.

Bunzow JR, Sonders MS, Arttamangkul S, Harrison LM, Zhang G, Quigley DI, Darland T, Suchland KL, Pasumamula S, Kennedy JL, Olson SB, Magenis RE, Amara SG, Grandy DK (2001) Amphetamine, 3,4-methylenedioxymethamphetamine, lysergic acid 
diethylamide, and metabolites of the catecholamine neurotransmitters are agonists of a rat trace amine receptor. Mol Pharmacol. 60: 1181-1188.

Cagetti E, Liang J, Spigelman I, Olsen RW (2003) Withdrawal from chronic intermittent ethanol treatment changes subunit composition, reduces synaptic function, and decreases behavioral responses to positive allosteric modulators of GABA receptors. Mol Pharmacol. 63: 53-64.

Caine SB, Thomsen M, Barrett AC, Collins GT, Grundt P, Newman AH, Butler P, Xu M (2012) Cocaine self-administration in dopamineD3 receptor knockout mice. Exp Clin Psychopharmacol. 20: 352-363.

Camarini R, Frussa-Filho R, Monteiro MG, Calil HM (2000) MK-801 blocks the development of behavioral sensitization to the ethanol. Alcohol Clin Exp Res. 24: 28590.

Carta M, Mameli M, Valenzuela CF (2004) Alcohol enhances GABAergic transmission to cerebellar granule cells via an increase in Golgi cell excitability. J Neurosci. 24: 37463751.

Cases O, Seif I, Grimsby J, Gaspar P, Chen K, Pournin S, Muller U, Aguet M, Babinet C, Shih JC (1995) Aggressive behavior and altered amounts of brain serotonin and norepinephrine in mice lacking MAOA. Science 268: 1763-1766.

Cases O, Vitalis T, Seif I, de Maeyer E, Sotelo C, Gaspar P (1996) Lack of barrels in the somatosensory cortex of monoamine oxidase A-deficient mice: role of a serotonina excess during the critical period. Neuron. 16: 297-307.

Chao HM (1995) Alcohol and the mystique of flushing. Alcohol Clin Exp Res. 19:104-109.

Chen K, Cases O, Rebrin I, Wu W, Gallaher TK, Seif I, Shih JC (2007) Forebrain-specific expression of monoamine oxidase A reduces neurotransmitter levels, restores the brain structure, and rescues aggressive behavior in monoamine oxidase A deficient mice. J Biol Chem. 282: 115-123.

Chen K, Holschneider DP, Wu W, Rebrin I, Shih JC (2004) A spontaneous point mutation produces monoamine oxidase A/B knock-out mice with greatly elevated monoamines and anxiety-like behavior. J Biol Chem. 279: 39645-39652.

Chen K, Wu HF, Grimsby J, Shih JC (1994) Cloning of a novel monoamine oxidase cDNA from trout liver. Mol Pharmacol. 46: 1226-1233.

Chen L, He M, Sibille E, Thompson A, Sarnyai Z, Baker H, Shippenberg T, Toth M (1999) Adaptive changes in postsynaptic dopamine receptors despite unaltered dopamine dynamics in mice lacking monoamine oxidase B. J Neurochem. 73: 647-655.

Chen Y, Yu A, Saari JT, Kang J (1997) Repression of hypoxia-reoxygenation injury in the catalase-overexpressing heart of transgenic mice. PSEBM. 216: 112-116.

Chiu VM, Schenk JO (2012) Mechanism of action of methamphetamine within the catecholamine and serotonin areas of the central nervous system. Curr Drug Abuse Rev. 5: 227-242. 
Cohen C, Curet O, Perrault G, Sanger DJ (1999) Reduction of oral ethanol selfadministration in rats by monoamine oxidase inhibitors. Pharmacol Biochem Behav. 64:535-9.

Cohen C, Perrault G, Voltz C, Steinberg R, Soubrie P (2002) SR141716, a central cannabinoid $(\mathrm{CB}(1))$ receptor antagonist, blocks the motivational and dopaminereleasing effects of nicotine in rats. Behav Pharmacol. 13: 451-463.

Cohen G, Sinet PM, Heikkila R (1980) Ethanol oxidation by rat brain in vivo. Alcohol Clin Exp Res. 4: 366-370.

Cohen JF, Elberling JA, DeMaster EG, Lin RC, Nagassawa HT (2000) N-Terminal dipeptides of $\mathrm{D}(-)$-penicillamine as sequestration agents for acetaldehyde. J Med Chem. 43: 10291033.

Correa M, Arizzi MN, Betz A, Mingote S, Salamone JD (2003) Open field locomotor effects in rats after intraventricular injections of ethanol and the ethanol metabolites acetaldehyde and acetate. Brain Res Bull. 62: 197-202.

Correa M, Miquel M, Aragon CMG (2000) Lead acetate potentiates brain catalase activity and enhances ethanol-induced locomotion in mice. Pharmacol Biochem and Behav. 66: 137-142.

Correa M, Miquel M, Sanchis-Segura C. Aragon CMG (1999b) Effects of chronic lead administration on ethanol-induced locomotion and brain catalase activity. Alcohol. 19: 43-49.

Correa M, Sanchis-Segura C, Pastor R, Aragon CM (2004) Ethanol intake and motor sensitization: The role of brain catalase activity in mice with different genotypes. Physiol Behav. 82: 231-240.

Craige CP, Unterwald EM (2012) Serotonin (2C) receptor regulation of cocaine-induced conditioned place preference and locomotor sensitization. Behav Brain Res. 238: 206210.

Cryan JF, Dalvi A, Jin SH, Hirsch BR, Lucki I, Thomas SA (2001) Use of dopaminebetahydroxylase-deficient mice to determine the role of norepinephrine inthemechanism of action of antidepressant drugs. J Pharmacol Exp Ther. 298: 651657.

Danielczyk W, Streifler M, Konradi C, Riederer P, Moll G (1988) Platelet MAO-B activity and the psychopathology of Parkinson's disease, senile dementia and multi-infarct dementia. Acta Psychiatr Scand. 78: 730-736.

Deng XS, Deitrich RA (2008) Putative role of brain acetaldehyde in ethanol addiction. 1: 38.

Devaud LL (2001) Ethanol dependence has limited effects on GABA or glutamate transporters in rat brain. Alcohol Clin Exp Res. 25: 606-611.

Di Chiara G, Bassareo V, Fenu S, De Luca MA, Spina L, Cadoni C, Acquas E, Carbont E, Valentini V, Lecca D (2004) Dompamine and drug addiction: the nuccleus accumbens shell connection. Neuropharmacology. 47: 227-241. 
Di Chiara G, Imperato A (1985) Ethanol preferentially stimulates dopamine release in the nucleus accumbens of freely moving rats. Eur J Pharmacol. 115: 131-132.

Diamond I, Gordon AS (1994) The role of adenosine in mediating cellular and molecular responses to ethanol. 71: 175-183.

Diana M, Peana AT, Sirca D, Lintas A, Melis M, Enrico P (2008) Crucial role of acetaldehyde in alcohol activation of the mesolimbic dopamine system. Ann N Y Acad Sci. 1139: 307-317.

Dohrman DP, Diamond I, Gordon AS (1997) The role of the neuromodulator adenosine in alcohol's actions. Alcohol Health Res World. 21: 136-143.

Donnelly CH, Murphy DL (1977) Substrate- and inhibitor-related characteristics of human platelet. Biochem Pharmacol. 26: 853-858.

Dubrovina NI, Popova NK, Gilinskii MA, Tomilenko RA, Seif I (2006) Acquisition and extinction of a conditioned passive avoidance reflex in mice with genetic knockout of monoamine oxidase A. Neurosci Behav Physiol. 36: 335-339.

Dudek BC, Tritto T (1994). Biometrical genetic analysis assay of the psychomotor stimulant effect of ethanol. Alcohol Clin Exp Res. 16: 347-353.

Durand D, Corrigall WA, Kujtan P, Carlen PL (1981) Effect of low concentrations of ethanol on CA1 hippocampal neurons in vitro. Can J Physiol Pharmacol. 59: 979-984.

Durlach J, Rinjard P, Sprince H, Smith GG (1988) Similar antagonistic effects of Ca Nacetylhomotaurinate on depression of motor activity and lethality induced by acetaldehyde or ethanol. Methods Fin Exp Clin Pharmacol. 10: 437-447.

Edmondson DE, Mattevi A, Binda C, Li M, HubaÅLlek F (2004) Structure and mechanism of monoamine oxidase. Curr Med Chem. 11: 1983-1993.

Eriksson CJP (2001) The role of acetaldehyde in the actions of alcohol (update 2000). Alcohol Clin Exp Res. 25: 15S-32S. [Suppl].

Escarabajal D, Miquel M, Aragon CMG (2000) A psychopharmacological study of the relationship between brain catalase activity and ethanol-induced locomotor activity in mice. J Stud Alcohol. 61: 493-498.

Escarabajal MD, Aragon CMG (2002) Concurrent administration of diethyldithiocarbamate and 4- ethylpyrazole enhances ethanol-induced locomotor activity: the role of brain ALDH. Psychopharmacology. 160: 339-343.

Escrig MA, Pardo M, Aragon CMG, Correa M (2012) Anxiogenic and stress-inducing effects of peripherally administered acetaldehyde in mice: Similarities with the disulfiramethanol reaction. Pharmacol Biochem and Beh. 100: 404-412

Eysseric H, Gonthier B, Soubeyran A, Bessard G, Saxod R, Barret L (1997) Characterization of the production of acetaldehyde by astrocytes in culture after ethanol exposure. Alcohol Clin Exp Res. 21: 1018-1023.

Fadda F, Rossetti ZL (1998) Chronic ethanol consumption: from neuroadaptation to neurodegeneration. Prog Neurobiol. 56: 385-431. 
Faingold CL, N'Gouemo P, Riaz A (1998) Ethanol and neurotransmitter interactions-from molecular to integrative effects. Prog Neurobiol. 55: 509-535.

Ferré S (2008) An update of the mechanisms of the psychostimulant effects of caffeine. J Neurochem. 105:1067-1079.

Filip M, Alenina N, Bader M, Przegaliński E (2010) Behavioral evidence for the significance of serotoninergic (5-HT) receptors in cocaine addiction. Addict Biol. 15: 227-249.

Filipenko ML, Beilina AG, Alekseyenko OV, Dolgov VV, Kudryavtseva NN (2002) Repeated experience of social defeats increases serotonin transporter and monoamine oxidase $\mathrm{A}$ mRNA levels in raphe nuclei of male mice. Neurosci Lett. 321: 25-28.

Fitzgerald JC, Ufer C, De Girolamo LA, Kuhn H, Billett EE (2007) Monoamine oxidaseAmodulates apoptotic cell death induced by staurosporine in human neuroblastoma cells. J Neurochem. 103: 2189-2199.

Font L, Aragon CMG, Miquel M (2006a) Ethanol-induced conditioned place preference, but not aversion, is blocked by treatement with D-penicillamine, an inactivation agent for acetaldehyde. Psychopharmacology. 184: 56-64.

Font L, Aragon CMG, Miquel M (2006b) Voluntary ethanol consumption decreases after the inactivation of central acetaldehyde by d-penicillamine. Behav Brain res. 171: 7886.

Font L, Miquel M, Aragon CM (2008) Involvement of brain catalase activity in the acquisition of ethanol-induced conditioned place preference. Physiol Behav. 93: 733741.

Font L, Miquel M, Aragon CMG (2005) Prevention of ethanol-induced behavioral stimulation by d-penicillamine: A sequestration agent for acetaldehyde. Alcohol Clin Exp Res. 29: 1156-1164.

Fornai F, Chen K, Giorgi FS, Gesi M, Alessandri MG, Shih JC (1999) Striatal dopamine metabolism in monoamine oxidase B-deficient mice: a brain dialysis study. J Neurochem. 73: 2434-2440.

Fowler H (1995) Curiosity and exploration behavior. Macmillan, New York. 1965.

Fox HH, Gibas JT (1953) Synthetic tuberculostats. V. Alkylidene derivatives of isonicotinylhydrazine, J. Org. Chem. 18: 983-989.

Garrick NA, Murphy DL (1980) Species differences in the deamination of dopamine and other substrates for monoamine oxidase in brain. Psychopharmacology. 72: 27-33.

Gill K, Mendez JF, Lucas D, Deitrich RA (1992) Enzymatic production of acetaldehyde form ethanol in the rat brain tissue. Alcohol Clin Exp Res. 16: 910-915.

Goldstein A (1995) Adicción. Ediciones en neurociencias. Rubes editorial, Barcelona.

González-Fraguela FJ (2000) Oxigen and free radicals. J Med Air Fis. 23: 7-37. 
Grimsby J, Chen K, Wang LJ, Lan NC, Shih JC (1991) Human monoamine oxidase A and B genes exhibit identical exon-intron organization. Proc Natl Acad Sci USA. 88: 36373641.

Grimsby J, Toth M, Chen K, Kumazawa T, Klaidman L, Adams JD, Karoum F, Gal J, Shih JC (1997) Increased stress response and beta-phenylethylamine in MAOB deficient mice. Nat Genet. 17: 206-210.

Grobin AC, Papadeas ST, Morrow AL (2000) Regional variations in the effects of chronic ethanol administration of $\mathrm{GABA}_{A}$ receptor expression: potential mechanisms. Neurochem Int. 37: 453-461.

Grünblatt E, SchloÅNsser R, Fischer P, Fischer MO, Li J, Koutsilieri E, Wichart I, Sterba N, Rujescu D, MoÅNller HJ, Adamcyk W, Dittrich B, Müller F, Oberegger K, Gatterer G, Jellinger KJ, Mostafaie N, Jungwirth S, Huber K, Tragl KH, Danielczyk W, Riederer P (2005) Oxidative stress related markers in the "VITA" and the centenarian projects. Neurobiol Aging. 26: 429-438.

Guaza C, Borrell S (1985) Brain catecholamines during ethanol administration, effect of naloxone on brain dopamine and norepinephrine responses to withdrawal from ethanol. Pharmacol Res Commun. 17: 1159-1167.

Hamby-Mason R, Chen JJ, Schenker S, Pérez A, Henderson GI (1997) Catalase mediates acetaldehyde formation from ethanol in fetal and neonatal rat brain. Alcohol Clin Exp Res. 21: 1063-1072.

Handler JA, Thurman RG(1985) Fatty acid-dependent ethanol metabolism. Biochem Biophys Res Commun. 133(1): 44-51.

Harris RA, Brodie MS, Dunwiddie TV (1992) Possible substrates of ethanol reinforcement: GABA and dopamine. Ann N Y Acad Sci. 654: 61-69.

Heap L, Ward RJ, Abiaka C, Dexter D, Lawlor M, Pratt O, Thomson A, Shaw K, Peters TJ (1995) The influence of acetaldehyde on oxidative status, dopamine metabolism and visual discrimination task. Biochem Pharmacol. 50: 263-270.

Heim WG, Appleman D, Pyform HT (1955) Production of catalase changes in animals with 3-amino-1,2,4-triazole. Science. 122: 693.

Hermida-Ameijeiras A, Méndez-Álvarez E, Sánchez-Iglesias S, Sanmartín-Suarez C, SotoOtero R (2004) Autoxidation and MAO-mediated metabolism of dopamine as potential cause of oxidative stress: role of ferrous and ferric ions. Neurochem Int. 45: 103-16.

Hipólito L, Sánchez MJ, Polache A, Granero L (2007) Brain metabolism of ethanol and alcoholism: an update. Curr Drug Metab. 8: 16-27.

Hodge CV, Chapelle AM, Samson HH (1995) GABAergic transmission in the nucleus accumbens is involved in the termination of ethanol self-administration in rats. Alcohol Clin Exp Res. 19: 1486-1493.

Holtzman SG, Schneider FH (1974) Comparison of acetaldehyde and ethanol: Depression of motor activity in mice. Life Sci. 14: 1243-1250.

Hunt WA (1985) Alcohol and biological membranes. The Guilford press. 
Hunt WA (1993) Neuroscience research: How has it contributed to our understanding of alcohol abuse and alcoholism? A review. Alcohol Clin Exp Res. 17: 1055-1065.

Hunt WA (1996) Role of acetaldehyde in the actions of ethanol on the brain-a review. Alcohol 13: 147-151.

Hyman SE, Malenka RC (2001) Addiction and the brain: the neurobiology of compulsion and its persistence. Nat Rev Neurosci. 2: 695-703.

Ito D, Lieber CS (1993) Ethanol metabolism in deermice: role of estrahepatic alcohol dehydrogenase. Alcohol Clin Exp Res. 17: 919-925.

Jahng JW, Houpt TA, Wessel TC, Chen K, Shih JC, Joh TH (1997) Localization of monoamine oxidase A and B mRNA in the rat brain by in situ hybridization. Synapse. 25: 30-36.

Jamal M, Ameno K, Kumihashi M, Wang W, Ameno S, Kubota T, Ijiri I (2003) Failure of ethanol and acetaldehyde to alter in vivo norepinephrine release in the striatum and hippocampus of rats. Arch Toxicol. 78: 723-727.

Jamal M, Ameno K, Uekita I, Kumihashi M, Wang W, Ijiri I (2007) Catalase mediates acetaldehyde formation in the striatum of free-moving rats. Neurotoxicology. 28: 12451248.

Johnston JP (1968) Some observations upon a new inhibitor of monoamine oxidase in brain tissue. Biochem Pharmacol. 17: 1285-1297.

Kamdar NK, Miller SA, Syed YM, Bhayana R, Gupta T, Rhodes JS (2007) Acute effects of naltrexone and GBR 12909 on ethanol drinking-in-the-dark in C57BL/6J mice. Psychopharmacology (Berl). 192: 207-217.

Karahanian E, Quintanilla ME, Tampier L, Rivera-Meza M, Bustamante D, Gonzalez-Lira V, Morales P, Herrera-Marschitz M, Israel Y (2011) Ethanol as a prodrug: brain metabolism of ethanol mediates its reinforcing effects. Alcohol Clin Exp Res. 35: 606612.

Katsura M, Torigoe F, Hayashida S, Honda T, Tsujimura A, Ohkuma S (2005) Ethanol physical dependence is acompained by up-regulated expression of L-type high voltagegated calcium channel alpha-1 subunits in mouse brain. Brain Res. 1039: 211-215.

Kelley AE. (1993) Locomotor activity and exploration. En: A Sahgal (ed): Behavioral neuroscience: A practical approach. Oxford University Press, pp 1-21.

Khanna JM, Kalant H, Shah G, Chau A (1991) Tolerance to ethanol and cross-tolerance to pentobarbital and barbital in four rat strains. Pharmacol. Biochem Behav. 39: 705-709.

Kim JJ, Shih JC, Chen K, Chen L, Bao S, Maren S, Anagnostaras SG, Fanselow MS, de Maeyer E, Seif I, Thompson RF (1997) Selective enhancement of emotional, but not motor, learning in monoamine oxidase A-deficient mice. Proc Natl Acad Sci USA. 94: 59295933

Kinoshita H, Harbuz MS, Nishiguchi M, Ouchi H, Minami T, Utsumi T, Motomura H, Hishida S (2004) High alcohol preferring (HAP) and low alcohol preferring (LAP) rats show altered propiomelanocortin (POMC) messenger RNA expression in the arcuate nucleus. Alcohol Alcohol. 39: 406-409. 
Kitanaka J, Kitanaka N, Takemura M (2006) Modification of monoaminergic activity by MAO inhibitors influences methamphetamine actions. Drug Target Insights. 1: 19-28.

Kitanaka N, Kitanaka J, Takemura M (2005) Inhibition of methamphetamine-induced hyperlocomotion inmice by clorgyline, a monoamine oxidase-a inhibitor, through alteration of the 5-hydroxytriptamine turnover in the striatum. Neuroscience. 130: 295-308.

Kitanaka N, Kitanaka J, Watabe K, Takemura M (2010) Low-dose pretreatment with clorgylina decreases the levels of 3-methoxy-4-hydroxyphenylglycol in the striatum and nucleus accumbens and attenuates methamphetamine-induced conditioned place preference in rats. Neuroscience. 165: 1370-1376.

Klein RL, Sanna E, McQuilkin SJ, Whiting PJ, Harris RA (1994) Effects of 5-HT3 receptor antagonists on binding and function of mouse on human $\mathrm{GABA}_{\mathrm{A}}$ receptors. Eur J Pharmacol. 268: 237-246.

Knoll J, Magyar K (1972) Some puzzling pharmacological effects of monoamine oxidase inhibitors. Adv Biochem Psychopharmacol. 5: 393-408.

Kobayashi S, Takahara K, Kamijo K (1981) Monoamine oxidase in frog liver and brain. Comp Biochem Physiol C. 69: 179-183.

Koechling UM, Amit Z (1994) Effects of 3-amino-1,2,4-triazole on brain catalase in the mediation of ethanol consumption in mice. Alcohol. 11: 235-239.

Konradi C, Kornhuber J, Froelich L, Fritze J, Heinsen H, Beckmann H, Schulz E, Riederer P (1989) Demonstration of monoamine oxidase-A and -B in the human brainstem by a histochemical technique. Neuroscience. 33: 383-400.

Kosenko E, Kaminsky Y, Kaminsky A, Valencia M, Lee L, Hermenegildo C, Felipo V (1997) Superoxide production and antioxidant enzymes in ammonia intoxication in rats. Free Radic Res. 27: 637-644

Lack AK, Floyd DW, McCool BA (2005) Chronic ethanol ingestion modulates proanxiety factors expressed in rat central amygdala. Alcohol. 36: 83-90.

Lands WEM (1998) A review of alcohol clearance in humans. Alcohol. 15: 147-160.

Le Marquand D, Phil RO, Benkefalt C (1994) Serotonin and alcohol intake, abuse and dependence; findings of animal studies. Biol Psychiatry. 36: 395-421.

Ledesma JC, Aragon CMG (2012) $\alpha$-Lipoic acid, a scavenging agent for H2O2, reduces ethanolstimulated locomotion in mice. Psychopharmacology (Berl) 219:171-180.

Ledesma JC, Aragon CMG (2013) Acquisition and reconditioning of ethanol-induced conditioned place preference in mice is blocked by the H2O2 scavenger alpha lipoic acid. Psychopharmacology (Berl) 226:673-685.

Ledesma JC, Baliño P, Aragon CMG (2014a) Reduction in central H2O2 levels prevents voluntary ethanol intake in mice: a role for the brain catalase-H2O2 system in alcohol binge drinking. Alcohol Clin Exp Res. 38: 60-67. 
Ledesma JC, Font L, Aragon CMG (2012) The H2O2 scavenger ebselen decreases ethanolinduced locomotor stimulation in mice. Drug Alcohol Depend. 124:42-49.

Ledesma JC, Miquel M, Pascual M, Guerri C, Aragon CM (2014b) Induction of brain cytochrome P450 2E1 boosts the locomotor-stimulating effects of ethanol in mice. Neuropharmacology. 85: 36-44.

Lee M, Chen K, Shih JC, Hiroi N (2004) MAO-B knockout mice exhibit deficient habituation of locomotor activity but normal nicotine intake. Genes Brain Behav. 3: 216-227.

Leslie SW, Weaver MS (1993) Sensitivity of NMDA receptors to acute and in utero ethanol exposure. En: Alling C, Diamond I, Leslie SW, Sun GY, Wood WG (eds): Alcohol, Cell Membranes and Signal Transduction in Brain. New York: Plenum Press, pp. 97-106.

Lieber CS, De Carli LM (1970) Hepatic microsomal ethanol-oxidizing system. J Biol Chem. 245: 2505-2512.

Lin TA, Navidi M, James W, Lin TN, Sun GY (1993) Effects of acute administration on polyphosphoinositide turnover and levels of inositol 1,4,5-triphosphate in mouse cerebrum and cerebellum. Alcohol Clin Exp Res. 17: 401-405.

Lovinger DM, Crabbe JC (2005) Laboratory models of alcoholism: treatment target identification and insight into mechanisms. Nat Neurosci. 8: 1471-1480.

Luque JM, Kwan SW, Abell CW, Da Prada M, Richards JG (1995) Cellular expression of mRNAs encoding monoamine oxidases $\mathrm{A}$ and $\mathrm{B}$ in the rat central nervous system. J Comp Neurol. 363:665-680.

Maiorino M, Roveri A, Coassin M, Ursini F (1988) Kinetic mechanism and substrate specificity of glutathione peroxidase activity of ebselen (PZ51). Biochem Pharmacol. 37: 2267-2271.

Mancillas JR, Siggins GR, Bloom FE (1986) Systemic ethanol selective enhancement of responses to acetylcholine and somatostatin in hippocampus. Science. 231: 161-163.

Manrique HM, Miquel M, Aragon CMG (2006) Acute administration of 3-nitropropionic acid, a reactive oxygen species generator, boosts ethanol-induced locomotor stimulation. New support for the role of brain catalase in the behavioural effects of ethanol. Neuropharmacology. 51: 1137-1145.

Margoliash E, Novogrodsky A, Schejter A. (1960) Irreversible reaction of 3-amino-1:2:4triazole and related inhibitors with the protein of catalase. Biochem J. 74: 339-348.

Marinelli PW, Quirion R, Gianulakis C (2003) A microdialysis profile of beta-endorphin and catecholamines in the rat nucleus accumbens following alcohol administration. Psychopharmacology. 169: 60-67.

Martí-Prats L, Sánchez-Catalán MJ, Hipólito L, Orrico A, Zornoza T, Polache A, Granero L (2010) Systemic administration of d-penicillamine prevents the activation after intraVTA ethanol administration in rats. Neurosci Lett. 483: 143-147.

Martinez SE, Vaglenova J, Sabria J, Martinez MC, Farres J, Pares X (2001) Distribution of alcohol dehydrogenase mRNA in the rat central nervous system. Consequences for brain ethanol and retinoid metabolism. Eur J Biochem. 268: 5045-5056. 
Matsuzawa S, Suzuki T, Misawa M (2000) Involvement of mu-opioid receptor in the salsolinol-associated place preference in rats exposed to conditioned fear stress. Alcohol Clin Exp Res. 24: 337-343.

McBride WJ, Lovinger DM, Machu T, Thielen RJ, Rodd ZA, Murphy JM, Roache JD, Johnson BA (2004) Serotonin-3 receptors in the actions of alcohol, alcohol reinforcement, and alcoholism. Alcohol Clin Exp Res. 28: 257-267.

McBride WJ, Murphy JM, Yoshimoto K, Lumeng L, Li TK (1993). Serotonin mechanisms in alcohol drinking behavior. Drug Dev Res. 30: 170-177.

Mega BT, Sheppard KW, Williams HL, McMillen BA (2002) On the role of monoamine oxidase-A for the maintenance of the volitional consumption of ethanol in two different rat models. Naunyn Schmiedebergs Arch Pharmacol. 366: 319-326.

Mejia JM, Ervin FR, Baker GB, Palmour RM (2002) Monoamine oxidase inhibition during brain development induces pathological aggressive behavior in mice. Biol Psychiatry. 52: 811-821.

Melis M, Enrico P, Peana AT, Diana M (2007) Acetaldehyde mediates alcohol activation of the mesolimbic dopamine system. Eur J Neurosci. 26: 2824-2833.

Meyer PJ, Phillips TJ (2003) Bivalent effects of MK-801 on ethanolinduced sensitization do not parallel its effects on ethanolinduced tolerance. Behav Neurosci. 117: 641-649.

Mihic SJ, Harris RA (1996) Alcohol actions at the $\mathrm{GABA}_{\mathrm{A}}$ receptor/chloride channel complex. En: Deitrich RA, Erwin VG, (eds) Pharmacological Effects of Ethanol in the Nervous System. Boca Raton, FL: CRL Press, pp: 51-72.

Miquel M, Font L, Sanchis-segura C, Aragon CMG (2003) Neonatal administration of monosodium glutamate prevents the development of ethanol- but not psychostimulant-induced sensitization: a putative role of the arcuate nucleus. Eur J Neurosci. 17: 2163-2170.

Miquel M, Pascual M, Guerri C, Aragon CMG (2005) The involvement of inducible CYPp450 2E1 in the behavioural effects of ethanol: a new support for the hypothesis of acetaldehyde. Abstract $10^{\text {th }}$ ESBRA. Alcohol and alcoholism 40, suppl. 1 .

Montoliu C, Valles S, Renau-Piqueras J, Guerri C (1994) Ethanol-induced oxygen radical formation and lipid peroxidation in rat brain: effect of chronic alcohol consumption. J Neurochem. 63: 1855-1862.

Moreno S, Mugnaini E, Cerù MP (1995) Immunocytochemical localization of catalase in the central nervous system of the rat. J Histochem Cytochem. 43: 1253-1267.

Mori O, Haseba T, Kameyama K, Shimizu H, Kudoh M, Ohaki O, Arai Y, Yamazaki M, Asano G (2000) Histological distribution of class III alcohol dehydrogenase in human brain. Brain Res. 852: 186-190.

Morrow AL (1995) Regulation of $\mathrm{GABA}_{\mathrm{A}}$ receptor function and gene expression in the central nervous system. Int Rev Neurobiol. 38: 1-41. 
Myers RD, Veale WL (1969) Alterations in volitional alcohol intake in rats by chronic intraventricular infusions of acetaldehyde, paraldehyde or methanol. Arch Int Pharmacodim Ther. 180: 100-113.

Myers WD, Ng K, Singer G (1984) Ethanol preference in rats with a prior history of acetaldehyde self-administration. Experientia. 40: 1008-1010.

Myers WD, NG KT, Singer G (1982) Intravenous self-administration of acetaldehyde in the rat as a functions of schedule, food deprivation and photoperiod. Pharmacol Biochem Behav. 17: 807-811.

Nagassawa HT, Goon DJ, DeMaster EG (1987) 2,5,5-Trimethylthiazone-4-carboxilic acid, a D(-)-penicillamine-directed pseudometabolite of ethanol. Detoxication mechanism for acetaldehyde. J Med Chem. 21: 1274-1279.

Nestby P, Vanderschuren LJ, De Vries TJ, Hogenboom F, Wardeh G, Mulder AH, Schoffelmeer AN (1997) Ethanol, like psychostimulants and morphine, causes longlasting hyperreactivity of dopamine and acetylcholine neurons of rat nucleus accumbens: possible role in behavioural sensitization. Psychopharmacology. 133: 6976.

Nestler EJ (2001) Molecular neurobiology of addiction. Am J Addict. 10: 201-217.

Nicotra A, Senatori O (1988) Changes in monoamine oxidase activity by mitochondria isolated from late embryos of Bufo bufo. Comp Biochem Physiol C. 89: 5-9.

Nie Z, Schweiter P, Roberts AJ, Madamba SG, Moore SD, Siggins GR (2004) Ethanol augments GABAergic transmission in the central amygdala via GRF1 receptors. Science. 303: 1512-1514.

Norris PJ, Hardwick JP, Emson PC (1994) Localization of NADPH cytochrome P450 oxidoreductase in rat brain by immunohistochemistry and in situ hybridation and a comparison with the distribution of neuronal NADPH-diaphorase staining. Neuroscience. 61: 331-350.

Nutt D (1999) Alcohol and the brain. Pharmacological insights for psychiatrists. Br J Psychiatry. 175:114-119.

Ollat H, Parvez H, Parvez S (1988) Alcohol and central neurotransmission. Neurochem Int. 13: $275-300$.

Ortiz S, Oliva JM, Perez-Rial S, Palomo T, Manzanares J (2004) Chronic ethanol consumption regulates cannabinoid CB1 receptor gene expression in selected regions of rat brain. Alcohol Alcohol. 39: 88-92.

Otis JM, Mueller D (2011) Inhibition of $\beta$-adrenergic receptors induces a persistent deficit in retrieval of a cocaine-associated memory providing protection against reinstatement. Neuropsychopharmacology. 36: 1912-1920.

Parnham M, Sies H (2000) Ebselen: prospective therapy for cerebral ischaemia. Expert Opin Investig Drugs. 9: 607-619.

Pastor R, Aragon CMG (2006) The Role of Opioid Receptor Subtypes in the Development of Behavioral Sensitization to Ethanol. Neuropsychopharmacology 31: 1489-1499 
Pastor R, Miquel M, Aragon CMG (2005) Habituation to test procedure modulates the involvement of dopamine D2- but not D1-receptors in ethanol-induced locmotor stimulation in mice. Psychopharmacology. 182: 436-446.

Pastor R, Sanchis-Segura C, Aragon CMG (2002) Ethanol-stimulated behavior in mice is modulated by brain catalse activity and $\mathrm{H} 2 \mathrm{O} 2$ rate of production. Psychopharmacology. 165: 51-59.

Peana AT, Assaretti AR, Muggironi G, Enrico P, Diana M (2009) Reduction of ethanolderived acetaldehyde induced motivational properties by L-cysteine. Alcohol Clin Exp Res. 33: 43-48.

Peana AT, Enrico P, Assaretti AR, Pulighe E, Muggironi G, Nieddu M, Piga A, Lintas A, Diana M (2008) Key role of ethanol-derived acetaldehyde in the motivational properties induced by intragastric ethanol: a conditioned place preference study in the rat. Alcohol Clin Exp Res. 32: 249-258.

Peana AT, Muggironi G, Calvisi G, Enrico P, Mereu M, Nieddu M, Boatto G, Diana M (2010) L-Cysteine reduces oral ethanol self-admininstration amd reinstatement of ethanoldrinking behaviour in rats. Pharmacol Biochem Behav. 94: 431-437.

Peoples RW, Li C, Weight FF (1996) lipid vs protein theories of alcohol action in the nervous system. Annu Rev Pharmcol Toxicol. 36: 185-201.

Pizzinat N, Copin N, Vindis C, Parini A, Cambon C (1999) Reactive oxygen species production by monoamine oxidases in intact cells. Naunyn Schmiedebergs Arch Pharmacol. 359: 428-431.

Pockros LA, Pentkowski NS, Conway SM, Ullman TE, Zwick KR, Neisewander JL (2012) 5HT(2A) receptor blockade and 5-HT(2C) receptor activation interact to reduce cocaine hyperlocomotion and Fos protein expression in the caudate-putamen. Synapse. 66: 989-1001.

Popova NK, Maslova LN, Morosova EA, Bulygina VV, Seif I (2006) MAO A knockout attenuates adrenocortical response to various kinds of stress. Psychoneuroendocrinology 31: 179-186.

Prus AJ, James JR, Rosecrans JA. (2009) Conditioned Place Preference. In: Buccafusco JJ, editor. Methods of Behavior Analysis in Neuroscience. 2nd edition. Boca Raton (FL): CRC Press Chapter 4.

Quertemont E, Green HL, Grant KA (2003). Brain ethanol concentrations and ethanol discrimination in rats: effects of dose and time. Psychopharmacology 168: 262-270.

Quertemont E, Tambour S, Bernaerts P, Zimatkin SM, Tirelli E (2004) Behavioral characterization of acetaldehyde in C57BL/6J mice: locomotor, hypnotic, anxiolytic and amnesic effects. Psychopharmacology. 177: 84-92.

Quertemont E, Tambour S, Tirelli E (2005) The role of acetaldehyde in the neurobehavioral effects of ethanol: a comprehensive review of animal studies. Prog Neurobiol. 75: 247-274.

Quetermont E, De Witte P (2001) Conditioned stimulus preference after acetaldehyde but not ethanol injections. Pharm Biochem Behav. 68: 449-454. 
Quintanilla ME, Tampier L (2003) Acetaldehyde reinforcing effects: differences in lowalcohol drinking (UCha) and high-alcohol drinking (UChb) rats. Alcohol. 31: 63-69.

Raskin NH, Sokoloff L (1972) Enzymes catalizing ethanol metabolism in neural and somatic tissues of the rat. J Neurochem. 19: 273-282.

Reddy BV, Boyadjeva N, Sarkar DK (1995) Effect of ethanol, propanol, butanol and catalase enzyme blockers on b-endorphin secretion from primary cultures of hypotalamic neurons: Evidence for a mediatory role of acetaldehyde in ethanol stimulation of bendorphin release. Alcohol Clin Exp Res. 19: 339-344.

Reddy BV, Sarkar DK (1993) Effect of alcohol, acetaldehyde and salsolinol on b-endorphin secretion from the hypotalamic neurons in primary cultures. Alcohol. Clin Exp Res 17: 161-167.

Rhodes JS, Best K, Belknap JK, Finn DA, Crabbe JC (2005) Evaluation of a simple model of ethanol drinking to intoxication in C57BL/6J mice. Physiol Behav. 84: 53-63.

Risner ME, Jones BE (1977) Characteristics of beta-phenethylamine self-administration by dog. Pharmacol biochem behav. 6: 689-696.

Roberto M, Madamba SG, Moore SD, Tallent MK, Siggins GR (2003) Ethanol increases GABAergic transmission at both pre- and postsynaptic sites in rat central amygdala neurons. Proc Nat acad Sci USA. 100: 2053-2058.

Roberto M, Madamba SG, Stouffer DG, Parsons LH, Siggins GR (2004) Increased GABA release in the central amygdala of ethanol-dependent rats. J Neurosci. 24: 1015910166.

Rodd-Henricks ZA, Melendez RI, Zaffaroni A, Goldstein A, McBride WJ, Li TK (2002). The reinforcing effects of acetaldehyde in the posterior ventral tegmental area of alcoholpreferring rats. Pharmacol Biochem Behav. 72: 55-64.

Rodriguez de Fonseca F, Del Arco I, Bermudez-Silva FJ, Bilbao A, Cippitelli A, Navarro M (2005) The endocannabinoid system: physiology and pharmacology. Alcohol Alcohol. 40: 2-14.

Rotzinger S, Smith BR, Amit Z (1994) Catalase inhibition attenuates the acquisition of ethanol and saccharin-quinine consumption in laboratory rats. Behav Pharmacol. 5: 203-209.

Rout UK (1992) Alcohol dehydrogenase in the brain of mice. Alcohol Clin Exp Res. 16: 286289.

Sabelli HC, Vazquez AJ, Flavin D (1975) Behavioral and electrophysiological effects of phenylethanolamine and 2-phenylethylamine. Psychopharmacologia 42: 117-125.

Sabria J, Torres D, Pasto M, Peralba JM, Allali-Hassani A, Pares X (2003) Release of neurotransmitters from rat brain nerve terminals after chronic etanol ingestión: differential effects in cortex and hippocampus. Addict Biol. 8: 287-294.

Sanchis-Segura C, Correa M, Aragon CMG (2000) Lession of the hypothalamic arcuate nucleus by estradiol valerate results in blockade of ethanol-induced locomotion. Behav Brain Res. 114: 57-63. 
Sanchis-Segura C, Miquel M, Correa C, Aragon CMG (1999a) Cyanamide reduces brain catalase and ethanol-induced locomotor activity: is there a functional link? Psychopharmacology. 144: 83-89.

Sanchis-Segura C, Miquel M, Correa M, Aragon CMG (1999b) Daily injections of cyanamide enhance both ethanol-induced locomotion and brain catalase activity. Behav Pharmacol. 10: 459-465.

Sanchis-Segura C, Miquel M, Correa M, Aragon CMG (1999c) The catalase inhibitor Sodium Azide reduces Ethanol-induced locomotor activity Alcohol. 19: 37-42.

Sanna PP, Simpson C, Lutjens R, Koob G (2002) ERK regulation in chronic ethanol exposure and withdrawal. Brain Res. 948: 186-191.

Sari Y (2013) Role of 5-hydroxytryptamine 1B (5-HT1B) receptors in the regulation of ethanol intake in rodents. J Psychopharmacol. 27: 3-12.

Schad A, Fahimi HD, Völkl A, Baumgart E (2003) Expression of catalase mRNA and protein in adult rat brain: detection by nonradioactive in situ hybridization with signal amplification by catalyzed reporter deposition (ISH-CARD) and immunohistochemistry (IHC)/immunofluorescence (IF). J Histochem Cytochem. 51: 751-760.

Schilling B, Lerch K (1995) Cloning, sequencing and heterologous expression of the monoamine oxidase gene from Aspergillus niger. Mol Gen Genet. 247: 430-438.

Scott AL, Bortolato M, Chen K, Shih JC (2008) Novel monoamine oxidase A knock out mice with human-like spontaneous mutation. Neuroreport. 19: 739-743.

Scremin OU, Holschneider DP, Chen K, Li MG, Shih JC (1999) Cerebral cortical blood flow maps are reorganized in MAOB-deficient mice. Brain Res. 824: 36-44.

Serrano E, Pozo OJ, Beltrán J, Hernández F, Font L, Miquel M, Aragon CMG (2007) Liquid chromatography/tandem mass spectrometry determination of (4S,2RS)-2,5,5trimethylthiazolidine-4-carboxylic acid, a stable adduct formed between D-(-)penicillamine and acetaldehyde (main biological metabolite of ethanol), in plasma, liver and brain rat tissues. Rapid Commun Mass Spectrom. 21: 1221-1229.

Setini A, Pierucci F, Senatori O, Nicotra A (2005) Molecular characterization of monoamine oxidase in zebrafish (Danio rerio). Comp Biochem Physiol B Biochem Mol Biol. 140: 153-161.

Shih JC, Chen K, Ridd MJ (1999) Monoamine oxidase: from genes to behavior. Annu Rev Neurosci. 22: 197-217.

Sirca D, Enrico P, Mereu M, Peana AT, Diana M (2011) L-cysteine prevents ethanolinduced stimulation of mesolimbic dopamine transmission. Alcohol Clin Exp Res. 35: 862-869.

Smith BR, Amit Z (1985) The role of gamma-aminobutiric acid (GABA) in the regulation of ethanol and acetaldehyde self-administration. Prog Neuropsychopharmacol Biol Psychiatry. 9: 759-763.

Smith BR, Amit Z, Aragon CMG, Socaransky SM (1985) Neurobiological correlates of ethanol self-administration: the role of acetaldehyde. En: Naranjo CA, Sellers EM, (eds): 
Research advances in new psychopharmacological treatments of alcoholism. Elsevier pp. $45-63$.

Smith BR, Amit Z, Splawinsky J (1984) Conditioned place preference induce by intraventricular infusions of acetaldehyde. Alcohol. 1: 193-195.

Somani SM, Husain K, Whitworth C, Trammell GL, Malafa M, Rybak LP (2000) Dosedependent protection by lipoic acid against cisplatin-induced nephrotoxicity in rats: antioxidant defense system. Pharmacol Toxicol. 86: 234-241.

Spina MB, Cohen G (1989) Dopamine turnover and glutathione oxidation: implications for Parkinson disease. Proc Natl Acad Sci U S A. 86: 1398-1400.

Stancampiano R, Carta M, Cocco S, Curreli R, Rossetti ZL, Fadda F (2004) Biphasic effects of acetylcholine release in the rat prefrontal. Brain Res. 997: 128-132.

Sulzer D, Sonders MS, Poulsen NW, Galli A (2005) Mechanisms of neurotransmitter release by amphetamines: a review. Prog Neurobiol. 75: 406-433.

Tabakoff B, Anderson RA, Ritzmann RF (1976) Brain acetaldehyde after ethanol administration. Biochem Pharmacol. 25: 1305-1309.

Tabakoff B, Hoffman PL (1987) Biochemical pharmacology of alcohol. Alcohol. 7: 15211526.

Tampier L, Quintanilla ME (2002) Effects of acetaldehyde on acute tolerance and ethanol consumption in drinker and non-drinker rats. J Stud Alcohol. 63: 257-262.

Tampier L, Quintanilla ME (2003) Involvement of brain ethanol metabolism on acute tolerance development and on ethanol consumption in alcohol-drinker (UChB) and non-drinker (UChA) rats. Addict Biol. 8: 279-286.

Techske R, Hasuura Y, Lieber CS (1976) Hepatic ethanol metabolism: Respectives roles of alcohol dehydrogenase, the microsomal ethanol-oxidizing system and catalase. Arch Biochem Biophisics. 175: 635-643.

Tephly TR, Mannering GJ, Parks Jr RE (1961) Studies on the mechanism of inhibition of liver and erythrocyte catalase activity by 3-amino-1,2,4-triazole (AT). J Pharmacol Exp Med. 134:77-82.

Thielen RJ, Bare DJ, McBride WJ, Lumeng L, Li TK (2002) Ethanol-stimulated serotonin release in the ventral hippocampus: an absence of rapid tolerance for the alcohol preferring $\mathrm{P}$ rat and insensitivity in the alcohol non-preferring NP rat. Pharmacol Biochem Behav. 71: 111-117.

Thurman RG, Handler JA (1989) New perspectives in catalase-dependent ethanol metabolism. Drug Metab Rev. 20: 679-688.

Upadhya SC, Tirumalai PS, Boyd MR, Mori T, Ravindranath V (2000) Cytochrome P4502E (CYP2E) in brain: constitutive expression, induction by ethanol and localization by fluorescence in situ hybridization. Arch Biochem Biophys. 373: 23-34. 
Vasconcellos SM, Cavalcante RA, Aguilar LM, Sousa FC, Fonteles MM, Viana GS (2004) Effects of chronic ethanol treatment on monoamine levels in rat hippocampus and striatum. Braz J Med Biol Res. 37: 1839-1846.

Vasiliou V, Ziegler TL, Bludeau P, Petersen DR, Gonzalez FJ, Deitrich RA (2006) CYP2E1 and catalase influence ethanol sensitivity in the central nervous system. Pharmacogenet Genomics. 16: 51-58.

Volz HP, Gleiter CH (1998) Monoamine oxidase inhibitors. A perspective on their use in the elderly. Drugs Aging. 13: 341-355.

Von Wartburg JP (1987) Acute aldehyde syndrome and chronic aldehydism. Mutat Res. 186: 249-259.

Wang DC, Taraschi TF, Rubin E, Janes N (1993) Configurational entropy is the driving force of ethanol action on membrane architecture. Biochim Byophis Acta. 1145-1148.

Weiner JL, Valenzuela CF (2006) Ethanol modulation of GABAergic transmission: The view from the slice. Pharmacol Ther. 111: 533-554.

Whibley A, Urquhart J, Dore J, Willatt L, Parkin G, Gaunt L, Black G, Donnai D, Raymond FL (2010) Deletion of MAOA and MAOB in a male patient causes severe developmental delay, intermittent hypotonia and stereotypical hand movements. Eur J Hum Genet. 18: 1095-1099.

Wise RA (2004) Dopamine, learning and motivation. Nat Rev Neurosci. 5: 483-494.

Wolinsky TD, Swanson CJ, Smith KE, Zhong H, Borowsky B, Seeman P, Branchek T, Gerald $\mathrm{CP}$ (2007) The trace amine 1 receptor knockout mouse: an animal model with relevance to schizophrenia. Genes Brain Behav. 6: 628-639.

Wright JM, Peoples RW, Weight FF (1996) Single-channel and whole-cell analysis of ethanol inhibition of NMDA-activated currents in cultured mouse cortical and hippocampal neurons. Brain Res. 738: 249-256.

Xie Z, Miller GM (2008) Beta-phenylethylamine alters monoamine transporter function via trace amine-associated receptor 1: implication for modulatory roles of trace amines in brain. J Pharmacol Exp Ther. 325: 617-628.

Yan QS, Zheng SZ, Feng MJ, Yan SE (2005) Involvement of 5-HT1B receptors within the ventral tegmental area in ethanol-induced increases in mesolimbic dopaminergic transmission. Brain Res. 1060: 126-137.

Yim HJ, Gonzales RA (2000) Ethanol-induced increases in dopamine extracellular concentration in rat nucleus accumbens are accounted for by increased release and not uptake inhibition. Alcohol. 22: 107-115.

Yin HS, Chen K, Kalpana S, Shih JC (2006) Differential effects of chronic amphetamine and baclofen administration on camp levels and phosphorylation of CREB in distinct brain regions of wild type and monoamine oxidase B-deficient mice. Synapse 60: 573-584.

Yoshimoto K, Ueda S, Kato B, Takeuchi Y, Kawai Y, Noritake K, Yasuhara M (2000) Alcohol enhances characteristic releases of dopamine and serotonin in the central nucleus of the amygdala. Neurochem Int. 37: 369-376. 
Yusa T, Beckman JS, Crapo JD, Freeman BA (1987) Hyperoxia increases H2O2 production by brain in vivo. J Appl Physiol. 63: 353-358.

Zeller EA, Barsky J (1952) In vivo inhibition of liver and brain monoamine oxidase by 1isonicotinyl-2-isopropyl hydrazine. Proc. Soc. Exp. Biol. NY 81: 459-461.

Zhang L, Hosoi M, Fukuzawa M, Sun H, Rawlings RR, Weight FF (2002) Distinct molecular basis for differential sensitivity of the serotonin type $3 \mathrm{~A}$ receptor to ethanol in the absence and presence of agonist. J Biol Chem. 277: 46256-46264.

Zimatkin SM, Buben AL (2007) Ethanol oxidation in the living brain. Alcohol Alcohol. 42: 529-32.

Zimatkin SM, Lindros KO (1996) Distribution of catalase in rat brain: aminergic neurons as possible targets for ethanol effects. Alcohol Alcohol. 31: 167-174. 